\title{
Simultaneous Discrimination of Hypochlorite and Single Oxygen during Sepsis by a Dual-Functional Fluorescent Probe
}

Lingliang Long, * Yuanyuan Han, Weiguo Liu, Qian Chen, Dandan Yin, LuLu Li, Fang Yuan, Zhixiang Han, Aihua Gong, ${ }^{*}$ Kun Wang*

School of Chemistry and Chemical Engineering, School of Medicine, School of the Environment and Safety Engineering, Key Laboratory of Modern Agriculture Equipment and Technology, Jiangsu University, Zhenjiang, Jiangsu 212013, P. R. China.

E-mail: longlingliang@ujs.edu.cn; ahg5@ujs.edu.cn; wangkun@ujs.edu.cn 
Table of Contents

Materials and instrumentation

page

Scheme S1

S3

Scheme S2

$\mathrm{S} 4$

Scheme S3

S4

Scheme S4

S5

Synthesis

S5

Preparation of the test solution

S6-S10

Determination of the fluorescence quantum yield

S10-11

Determination of the detection limit

S11

Cell culture

S11

Fluorescence imaging

S11-12

Computational details

S12-13

Figure S1

$\mathrm{S} 13$

Figure S2

S14

Figure S3

S14

Figure S4

S15

Table S1

S15

Figure S5

S16

Figure S6

S17

Scheme S5

S17

Scheme S6

S18

Figure S7

S18

Figure S8

S19

Figure S9

S19

Figure S10

S20

Figure S11

S20

Figure S12

S21

Table S2

S21

Figure S13

S22

Table S3

S22

Table S4

S23

Figure S14

S24

Figure S15-S22

S25

Figure S23-S26

S25-29

Figure S27-S56

S29-31

References

S32-46

S47-48 


\section{Materials and instruments}

Unless otherwise noted, all reagents were purchased from commercial suppliers and used without further purification. Solvents were purified and dried by standard methods prior to use. Doubly distilled water was used in all experiments. TLC analyses were performed on silica gel plates and column chromatography was conducted over silica gel (mesh 200-300), both of which were obtained from Qingdao Ocean Chemicals. Melting points were measured on a Beijing Taike XT-4 microscopic melting point apparatus. All melting points are uncorrected. Mass spectra were recorded on a LXQ Spectrometer (Thermo Scientific) operating in the ESI mode. ${ }^{1} \mathrm{H}$ and ${ }^{13} \mathrm{C}-\mathrm{NMR}$ spectra were recorded on a Bruker Avance 400 spectrometer operating at $400 \mathrm{MHz}$ and 100 $\mathrm{MHz}$, respectively. Elemental $(\mathrm{C}, \mathrm{H}, \mathrm{N})$ analyses were carried out using a Flash EA 1112 analyzer. The Crystallographic data were collected on a Saturn $724^{+}$CCD X-ray diffractometer by using graphite monochromated Mo $K \alpha(\lambda=0.71070 \AA)$. Electronic absorption spectra were recorded on a SHIMADZU UV-2450 spectrometer. Fluorescence spectra were measured on a Photon Technology International (PTI) Quantamaster fluorimeter using $2 \mathrm{~nm}$ excitation and emission slit widths, respectively. Tissue was sectioned with Lecia RM 2145 microtome. Confocal fluorescence microcopy imaging experiments were performed on a Leica TCS SP5 II laser confocal scanning microscope. $\mathrm{pH}$ measurements were performed with a $\mathrm{pH}-3 \mathrm{c}$ digital $\mathrm{pH}$-meter (Shanghai ShengCi Device Works, Shanghai, China) with a combined glass-calomel electrode. 



Scheme S1. The synthetical procedures for compound 1.

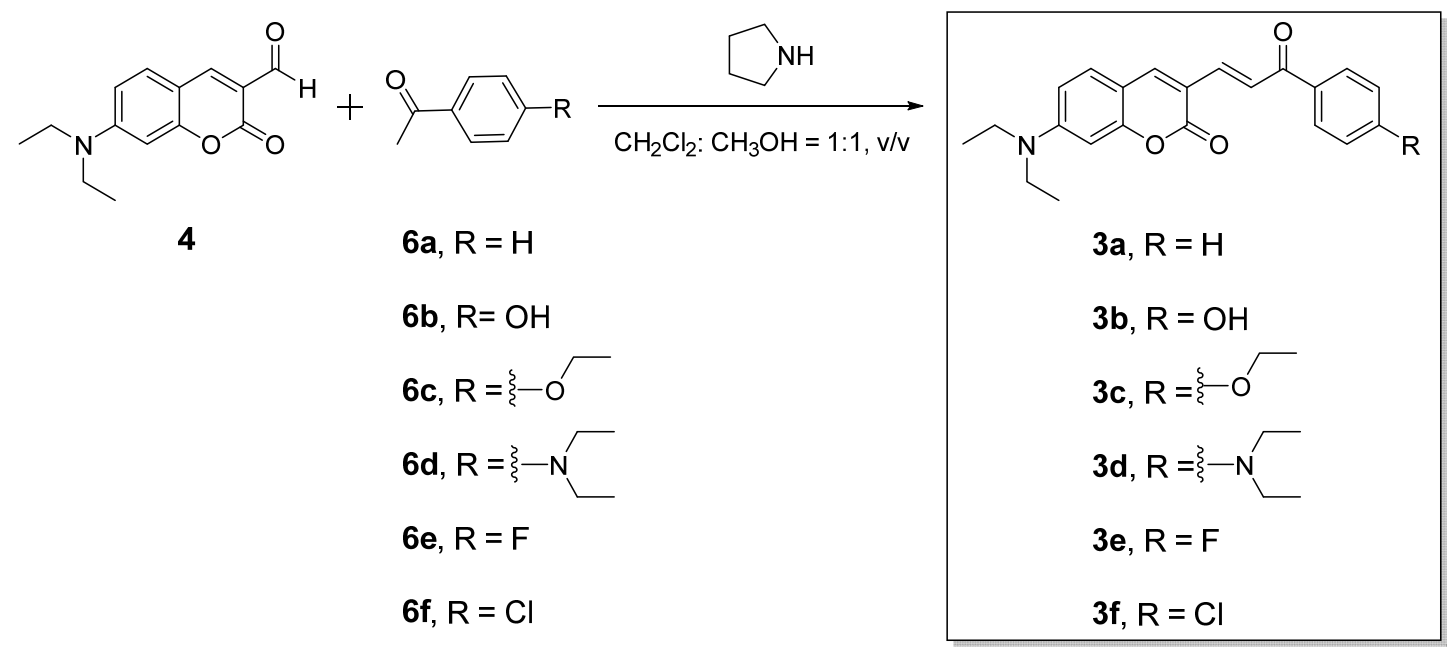

Scheme S2. The synthetical procedures for compound 3a-3f. 


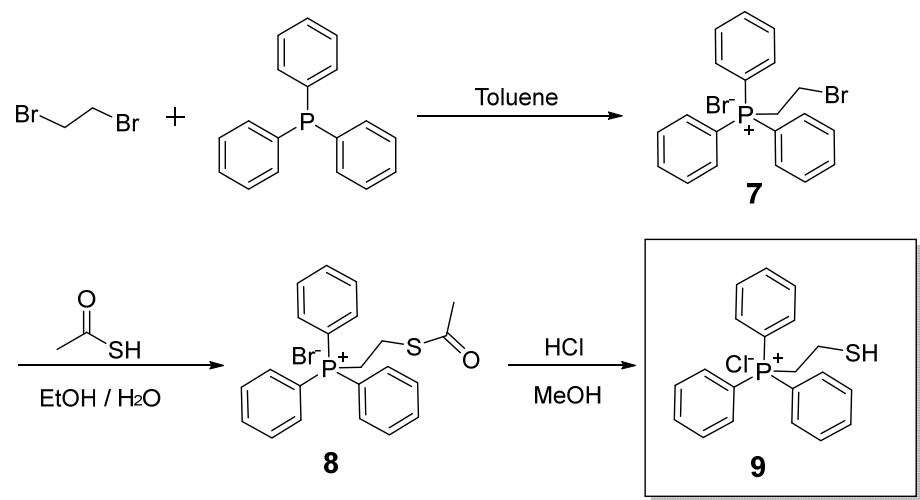

Scheme S3. The synthetical procedures for compound 9.
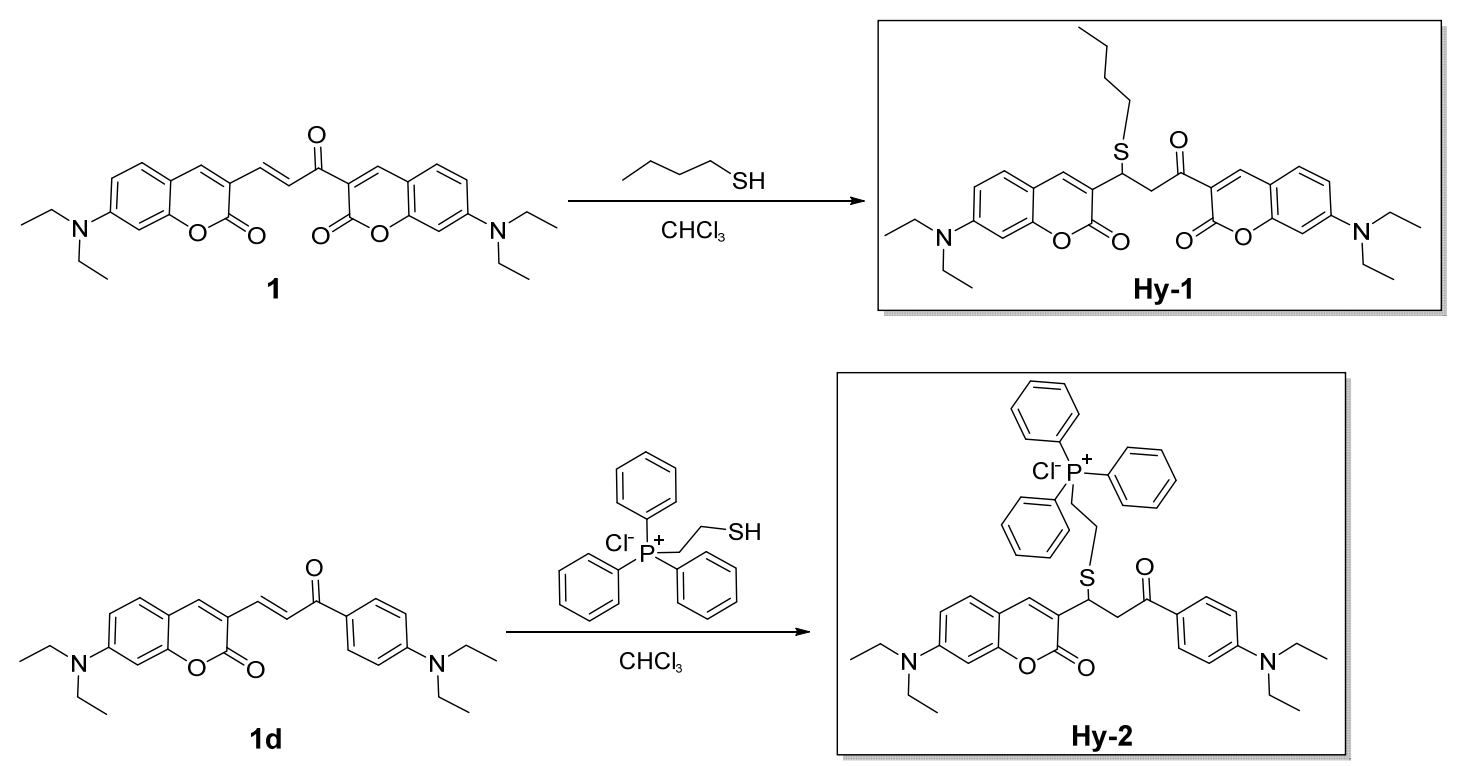

Scheme S4. The synthetical procedure for compound Hy-1 and Hy-2. 


\section{Synthesis of compound 4}

4-(Diethylamino) salicylaldehyde (3 g, $15.5 \mathrm{mmol})$, diethyl malonate $(4.7 \mathrm{~mL}, 31 \mathrm{mmol})$ and piperidine $(0.83 \mathrm{~mL}, 15.5 \mathrm{mmol})$ were dissolved in absolute ethanol $(20 \mathrm{~mL})$ in a $100 \mathrm{~mL}$ round-bottom flask equipped with a reflux condenser. The stirred mixture was heated at reflux for 7 hours. After cooled to room temperature, excess ethanol in the mixture was removed under reduced pressure. Then, acetic acid $(10 \mathrm{~mL})$ and hydrochloric acid $(10 \mathrm{~mL})$ were added into the mixture at $0^{\circ} \mathrm{C}$ (in an ice bath). The resulting mixture was further stirred at $100{ }^{\circ} \mathrm{C}$ for 12 hours. Subsequently, the $\mathrm{pH}$ of the mixture was adjusted to 5 by addition of $\mathrm{NaOH}$ solution $(1 \mathrm{M})$. The resulting precipitate was collected by filtration and was further purified by recrystallization in anhydrous ethanol to afford compound a as yellow solid. Then a mixture of $\mathrm{POCl}_{3}(5$ $\mathrm{mL}$ ) and DMF ( $5 \mathrm{~mL}$ ) in a $50 \mathrm{~mL}$ round-bottom flask was stirred at $0{ }^{\circ} \mathrm{C}$ (in an ice bath) for $40 \mathrm{~min}$. Subsequently, compound a (2 g, $9.2 \mathrm{mmol})$ in $7.5 \mathrm{~mL}$ DMF was added to the mixture. The resulting mixture solution was further stirred at $65{ }^{\circ} \mathrm{C}$ for 13 hours, and then the $\mathrm{pH}$ of the solution was adjusted to 5 by addition of $\mathrm{NaOH}$ solution $(1 \mathrm{M})$. The precipitate formed was collected by filtration and was further purified by recrystallization in anhydrous ethanol to afford compound 4 (yield: $4.6987 \mathrm{~g}, 69.8 \%$ ) as a yellow solid. Mp: $152-154{ }^{\circ} \mathrm{C} ;{ }^{1} \mathrm{H} \mathrm{NMR}\left(400 \mathrm{MHz}, \mathrm{CDCl}_{3}\right) \delta=10.13(\mathrm{~s}, 1 \mathrm{H}), 8.26$ (s, $1 \mathrm{H}), 7.41(\mathrm{~d}, J=8.8 \mathrm{~Hz}, 1 \mathrm{H}), 6.64(\mathrm{dd}, J=2.4 \mathrm{~Hz}, 8.8 \mathrm{~Hz}, 1 \mathrm{H}), 6.49$ (d, $J=2.4 \mathrm{~Hz}$, $1 \mathrm{H}), 3.48(\mathrm{q}, J=7.2 \mathrm{~Hz}, 4 \mathrm{H}), 1.26(\mathrm{t}, J=7.2 \mathrm{~Hz}, 6 \mathrm{H})$; $\mathrm{MS}(\mathrm{m} / \mathrm{z}): 246.1[\mathrm{M}+\mathrm{H}]^{+}$.

\section{Synthesis of compound 5}

4-(Diethylamino) salicylaldehyde ( $2 \mathrm{~g}, 10.4 \mathrm{mmol})$, ethyl acetoacetate $(1.32 \mathrm{~mL}, 10.4$ mmol) and piperidine $(0.56 \mathrm{~mL}, 10.4 \mathrm{mmol})$ were dissolved in $20 \mathrm{~mL}$ methanol. The mixture was further stirred for 6 hours at room temperature. After that, the resulting orange precipitate was collected by filtration and was further purified by recrystallization in anhydrous ethanol to afford orange solid (1.75, yield 65\%). Mp: $152-154{ }^{\circ} \mathrm{C} ;{ }^{1} \mathrm{H}$ NMR $\left(400 \mathrm{MHz}, \mathrm{CDCl}_{3}\right) \delta=8.45(\mathrm{~s}, 1 \mathrm{H}), 8.26(\mathrm{~s}, 1 \mathrm{H}), 7.41(\mathrm{~d}, J=8.8$ $\mathrm{Hz}, 1 \mathrm{H}), 6.65(\mathrm{dd}, J=2.4 \mathrm{~Hz}, 8.8 \mathrm{~Hz}, 1 \mathrm{H}), 6.50(\mathrm{~d}, J=2.4 \mathrm{~Hz}, 1 \mathrm{H}), 3.36$ (q, $J=7.2$ $\mathrm{Hz}, 4 \mathrm{H}), 2.37(\mathrm{~s}, 3 \mathrm{H}), 1.12(\mathrm{t}, J=7.2 \mathrm{~Hz}, 6 \mathrm{H}) ; \mathrm{MS}(\mathrm{m} / \mathrm{z}): 260.18[\mathrm{M}+\mathrm{H}]^{+}$.

\section{Synthesis of compound 1}

Compound 4 (500 mg, $2.04 \mathrm{mmol}$ ), compound 5 (528 mg, $2.04 \mathrm{mmol})$, and pyrrolidine $(82 \mu \mathrm{L}, 0.98 \mathrm{mmol})$ were dissolved in $6 \mathrm{~mL} \mathrm{CH}_{2} \mathrm{Cl}_{2} / \mathrm{CH}_{3} \mathrm{OH}(\mathrm{v}: \mathrm{v}=1: 1)$. The mixture was stirred at room temperature for $24 \mathrm{~h}$. After the solvents removed under reduced pressure, the residue was purified by column chromatograph $\left(\mathrm{CH}_{2} \mathrm{Cl}_{2}\right.$ : petroleum ether $=1: 2, \mathrm{v} / \mathrm{v})$ to afford a red solid (109 mg, yield 11\%). Mp: 203-204 ${ }^{\circ} \mathrm{C} ;{ }^{1} \mathrm{H} \mathrm{NMR}\left(\mathrm{CDCl}_{3}\right.$, $400 \mathrm{MHz}), \delta(\mathrm{ppm}): 8.49(\mathrm{~s}, 1 \mathrm{H}), 8.28(\mathrm{~d}, J=15.6 \mathrm{~Hz}, 1 \mathrm{H}), 7.92(\mathrm{~s}, 1 \mathrm{H}), 7.83(\mathrm{~d}, J=$ $15.6 \mathrm{~Hz}, 1 \mathrm{H}), 7.40(\mathrm{~d}, J=9.2 \mathrm{~Hz}, 1 \mathrm{H}), 7.33(\mathrm{~d}, J=8.8 \mathrm{~Hz}, 1 \mathrm{H}), 6.61(\mathrm{~m}, 2 \mathrm{H}), 6.48(\mathrm{~m}$, 2H), 3.45 (m, 8H), $1.24(\mathrm{~m}, 12 \mathrm{H}) ;{ }^{13} \mathrm{C} \mathrm{NMR}\left(\mathrm{CDCl}_{3}, 100 \mathrm{MHz}\right), \delta(\mathrm{ppm}): 186.5,160.7$, 158.6, 156.8, 152.8, 151.6, 148.3, 142.8, 137.8, 131.6, 129.9, 125.0, 117.2, 115.7, 109.8, 109.4, 108.9, 108.6, 97.1, 96.7, 45.2, 45.0, 12.5; MS (ESI) m/z 487.22 [M+H] ; Elemental analysis calcd (\%) for $\mathrm{C}_{29} \mathrm{H}_{30} \mathrm{~N}_{2} \mathrm{O}_{5}$ : C 71.59; H 6.21; N 5.76; found C 71.28, H 6.23, N 5.63. 


\section{Synthesis of compound 3a}

Compound 4 (500 mg, $2.04 \mathrm{mmol})$, acetophenone 6a (245.1 mg, $2.04 \mathrm{mmol})$, and pyrrolidine $(82 \mu \mathrm{L}, 0.98 \mathrm{mmol})$ were dissolved in $6 \mathrm{~mL} \mathrm{CH}_{2} \mathrm{Cl}_{2} / \mathrm{CH}_{3} \mathrm{OH}(\mathrm{v}: \mathrm{v}=1: 1)$. The mixture was stirred at room temperature overnight. After the solvents removed under reduced pressure, the residue was purified by column chromatograph $\left(\mathrm{CH}_{2} \mathrm{Cl}_{2}\right.$ : petroleum ether $=1: 1, \mathrm{v} / \mathrm{v})$ to afford an orange solid $(141 \mathrm{mg}$, yield 20\%). Mp: 113$116{ }^{\circ} \mathrm{C} ;{ }^{1} \mathrm{H}$ NMR $\left(\mathrm{CDCl}_{3}, 400 \mathrm{MHz}\right), \delta(\mathrm{ppm}): 8.23(\mathrm{~d}, J=15.2 \mathrm{~Hz}, 1 \mathrm{H}), 8.09(\mathrm{~d}, J=$ $6.8 \mathrm{~Hz}, 2 \mathrm{H}), 7.79(\mathrm{~s}, 1 \mathrm{H}), 7.64(\mathrm{~d}, J=15.2 \mathrm{~Hz}, 1 \mathrm{H}), 7.56(\mathrm{~m}, 1 \mathrm{H}), 7.50(\mathrm{~m}, 1 \mathrm{H}), 7.33$ $(\mathrm{d}, J=8.8 \mathrm{~Hz}, 1 \mathrm{H}), 6.62(\mathrm{dd}, J=2.4 \mathrm{~Hz}, 8.8 \mathrm{~Hz}, 1 \mathrm{H}), 6.51(\mathrm{~d}, J=2.4 \mathrm{~Hz}, 1 \mathrm{H}), 3.45(\mathrm{~m}$, 4H), 1.21 (t, $J=7.2 \mathrm{~Hz}, 6 \mathrm{H}) ;{ }^{13} \mathrm{C} \mathrm{NMR}\left(\mathrm{CDCl}_{3}, 100 \mathrm{MHz}\right), \delta(\mathrm{ppm}): 190.8,160.2$, 156.6, 151.9, 146.1 139.8, 138.4, 132.6, 129.9, 128.6, 128.5, 123.0, 115.1, 109.5, 108.9, 96.9, 45.0, 12.5; MS (ESI) $\mathrm{m} / \mathrm{z} 368.26[\mathrm{M}+\mathrm{Na}]^{+}$; Elemental analysis calcd (\%) for $\mathrm{C}_{22} \mathrm{H}_{21} \mathrm{NO}_{3}$ : C 76.06; H 6.09; N 4.03; found C 76.03, H 6.11, N 4.02.

\section{Synthesis of compound $\mathbf{3 b}$}

Compound 4 (500 mg, $2.04 \mathrm{mmol})$, hydroxyacetophenone $6 \mathbf{b}(277 \mathrm{mg}, 2.04 \mathrm{mmol})$, and pyrrolidine $(82 \mu \mathrm{L}, 0.98 \mathrm{mmol})$ were dissolved in $6 \mathrm{~mL} \mathrm{CH}_{2} \mathrm{Cl}_{2} / \mathrm{CH}_{3} \mathrm{OH}$ (v:v $\left.=1: 1\right)$. The mixture was stirred at room temperature overnight. After the solvents removed under reduced pressure, the residue was purified by column chromatograph $\left(\mathrm{CH}_{2} \mathrm{Cl}_{2}\right.$ : petroleum ether $=1: 1, \mathrm{v} / \mathrm{v})$ to afford an orange solid $(135 \mathrm{mg}$, yield $18 \%)$. Mp: 141$144{ }^{\circ} \mathrm{C} ;{ }^{1} \mathrm{H}$ NMR (DMSO- $\left.d_{6}, 400 \mathrm{MHz}\right), \delta(\mathrm{ppm}): 10.43(\mathrm{~s}, 1 \mathrm{H}), 8.43(\mathrm{~s}, 1 \mathrm{H}), 8.01$ (d, $J=15.6 \mathrm{~Hz}, 1 \mathrm{H}), 7.96(\mathrm{~d}, J=8.8 \mathrm{~Hz}, 2 \mathrm{H}), 7.60(\mathrm{~d}, J=15.6 \mathrm{~Hz}, 1 \mathrm{H}), 7.48(\mathrm{~d}, J=9.2$ $\mathrm{Hz}, 1 \mathrm{H}), 6.91$ (d, $J=8.8 \mathrm{~Hz}, 2 \mathrm{H}), 6.78(\mathrm{dd}, J=2.4 \mathrm{~Hz}, 8.8 \mathrm{~Hz}, 1 \mathrm{H}), 6.58(\mathrm{~d}, J=2.4$, 1H), $3.47(\mathrm{~m}, 4 \mathrm{H}), 1.14(\mathrm{t}, J=6.8 \mathrm{~Hz}, 6 \mathrm{H}) ;{ }^{13} \mathrm{C}$ NMR (DMSO-do, $\left.100 \mathrm{MHz}\right), \delta$ (ppm):187.5, 162.5, 160.5, 156.8, 152.2, 145.5, 138.5, 131.2, 130.9, 129.9, 121.5, 115.9, 113.9, 110.3, 108.8, 96.7, 44.8, 12.8; MS (ESI) m/z 364.15 [M+H] ${ }^{+}$; Elemental analysis calcd (\%) for $\mathrm{C}_{22} \mathrm{H}_{21} \mathrm{NO}_{4}$ : C 72.71; H 5.82; N 3.85; found C 72.37, H 5.84, N 3.83.

\section{Synthesis of compound $3 \mathrm{c}$}

Compound 4 (500 mg, $2.04 \mathrm{mmol})$, 4-ethoxyacetophenone 6c (335 mg, $2.04 \mathrm{mmol})$, and pyrrolidine $(82 \mu \mathrm{L}, 0.98 \mathrm{mmol})$ were dissolved in $6 \mathrm{~mL} \mathrm{CH}_{2} \mathrm{Cl}_{2} / \mathrm{CH}_{3} \mathrm{OH}$ (v:v $\left.=1: 1\right)$. The mixture was stirred at room temperature overnight. After the solvents removed under reduced pressure, the residue was purified by column chromatograph $\left(\mathrm{CH}_{2} \mathrm{Cl}_{2}\right.$ : petroleum ether $=1: 1, \mathrm{v} / \mathrm{v})$ to afford an orange solid $(129 \mathrm{mg}$, yield 16\%). Mp: 147$151{ }^{\circ} \mathrm{C} ;{ }^{1} \mathrm{H} \mathrm{NMR}\left(\mathrm{CDCl}_{3}, 400 \mathrm{MHz}\right), \delta(\mathrm{ppm}): 8.25(\mathrm{~d}, J=15.2 \mathrm{~Hz}, 1 \mathrm{H}), 8.09(\mathrm{~m}, 2 \mathrm{H})$, $7.77(\mathrm{~s}, 1 \mathrm{H}), 7.61(\mathrm{~d}, J=15.2 \mathrm{~Hz}, 1 \mathrm{H}), 7.33(\mathrm{~d}, J=9.2 \mathrm{~Hz}, 1 \mathrm{H}), 6.96(\mathrm{~m}, 2 \mathrm{H}), 6.61(\mathrm{dd}$, $J=2.4 \mathrm{~Hz}, 8.8 \mathrm{~Hz}, 1 \mathrm{H}), 6.51(\mathrm{~d}, J=2.4,1 \mathrm{H}), 4.12(\mathrm{~m}, 2 \mathrm{H}), 3.45(\mathrm{~m}, 4 \mathrm{H}), 1.45(\mathrm{t}, J=$ $6.8 \mathrm{~Hz}, 3 \mathrm{H}), 1.24$ (t, $J=6.8 \mathrm{~Hz}, 6 \mathrm{H}) ;{ }^{13} \mathrm{C} \mathrm{NMR}\left(\mathrm{CDCl}_{3}, 100 \mathrm{MHz}\right), \delta(\mathrm{ppm}): 189.0$, $162.8,160.3,156.5,151.8,145.9,138.9,131.2,130.9,129.9,123.0,115.2,114.2,109.5$, 108.9, 96.9, 63.7, 45.0, 14.7, 12.5; MS (ESI) m/z $392.13[\mathrm{M}+\mathrm{H}]^{+}$; Elemental analysis calcd (\%) for $\mathrm{C}_{24} \mathrm{H}_{25} \mathrm{NO}_{4}$ : C 73.64; H 6.44; N 3.58; found C 73.29, H 6.47, N 3.56.

\section{Synthesis of compound 6d}

A solution of 4-aminoacetophenone $(6.0 \mathrm{~g}, 44.4 \mathrm{mmol})$, iodoethane $(8.1 \mathrm{~mL})$, and 
$\mathrm{K}_{2} \mathrm{CO}_{3}(13.8 \mathrm{~g}, 0.1 \mathrm{~mol})$ in DMF $(20 \mathrm{~mL})$ was refluxed for $24 \mathrm{~h}$. After cooled to room temperature, the mixture was poured into ice water. The precipitate was collected by filtration and futher purified by column chromatograph $\left(\mathrm{CH}_{2} \mathrm{Cl}_{2}\right.$ : petroleum ether $=1: 2$, $\mathrm{v} / \mathrm{v})$ to afford white solid (6.4 g, yield 75\%). Mp: 47-49 ${ }^{\circ} \mathrm{C} ;{ }^{1} \mathrm{H}$ NMR (400 MHz, Methanol- $\left.d_{4}\right), \delta(\mathrm{ppm}): 7.83(\mathrm{~d}, J=9.2 \mathrm{~Hz}, 1 \mathrm{H}), 7.78(\mathrm{~m}, 1 \mathrm{H}), 6.69(\mathrm{dd}, J=2 \mathrm{~Hz}, 6.8$ $\mathrm{Hz}, 1 \mathrm{H}), 6.58(\mathrm{~d}, J=8.8 \mathrm{~Hz}, 1 \mathrm{H}), 3.46(\mathrm{~m}, 2 \mathrm{H}), 3.19(\mathrm{~m}, 2 \mathrm{H}), 2.46(\mathrm{~s}, 3 \mathrm{H}), 1.21(\mathrm{~m}$, $6 \mathrm{H})$; MS $(\mathrm{m} / \mathrm{z}): 192.13[\mathrm{M}+\mathrm{H}]^{+}$.

\section{Synthesis of compound 3d}

Compound 4 (500 mg, $2.04 \mathrm{mmol}$ ), compound 6d (389.9 mg, $2.04 \mathrm{mmol})$, and pyrrolidine $(82 \mu \mathrm{L}, 0.98 \mathrm{mmol})$ were dissolved in $6 \mathrm{~mL} \mathrm{CH}_{2} \mathrm{Cl}_{2} / \mathrm{CH}_{3} \mathrm{OH}(\mathrm{v}: \mathrm{v}=1: 1)$. The mixture was stirred at room temperature for $24 \mathrm{~h}$. After the solvents removed under reduced pressure, the residue was purified by column chromatograph $\left(\mathrm{CH}_{2} \mathrm{Cl}_{2}\right.$ : petroleum ether $=1: 2, \mathrm{v} / \mathrm{v})$ to afford an orange solid $(102 \mathrm{mg}$, yield 12\%). Mp: 110$114{ }^{\circ} \mathrm{C} ;{ }^{1} \mathrm{H} \mathrm{NMR}\left(\mathrm{CDCl}_{3}, 400 \mathrm{MHz}\right), \delta(\mathrm{ppm}): 8.26(\mathrm{~d}, J=15.2 \mathrm{~Hz}, 1 \mathrm{H}), 8.04(\mathrm{~d}, J=$ $9.2 \mathrm{~Hz}, 2 \mathrm{H}), 7.73(\mathrm{~s}, 1 \mathrm{H}), 7.58(\mathrm{~d}, J=15.2 \mathrm{~Hz}, 1 \mathrm{H}), 7.30(\mathrm{~d}, J=9.2 \mathrm{~Hz}, 1 \mathrm{H}), 6.67$ (d, $J=8.8 \mathrm{~Hz}, 2 \mathrm{H}), 6.59(\mathrm{dd}, J=2.4 \mathrm{~Hz}, 8.8 \mathrm{~Hz}, 1 \mathrm{H}), 6.48(\mathrm{~d}, J=2.4 \mathrm{~Hz}, 1 \mathrm{H}), 3.43$ (m, $8 \mathrm{H}), 1.21(\mathrm{~m}, 12 \mathrm{H}) ;{ }^{13} \mathrm{C} \mathrm{NMR}\left(\mathrm{CDCl}_{3}, 100 \mathrm{MHz}\right), \delta(\mathrm{ppm}): 187.9,160.4,156.3,151.5$, 151.1, 145.2, 137.4, 131.3, 129.7, 125.6, 123.7, 115.7, 110.3, 109.4, 108.9, 96.9, 77.4, 77.1, 76.7, 44.9, 44.5, 12.6, 12.5; MS (ESI) m/z 419.12 [M+H] $]^{+}$; Elemental analysis calcd (\%) for $\mathrm{C}_{26} \mathrm{H}_{30} \mathrm{~N}_{2} \mathrm{O}_{3}$ : C 74.61; H 7.23; N 6.69; found C 74.59, H 7.25, N 6.66.

\section{Synthesis of compound $3 \mathrm{e}$}

Compound 4 (500 mg, $2.04 \mathrm{mmol})$, 4-fluoroacetophenone 6e (282 mg, $2.04 \mathrm{mmol})$, and pyrrolidine $(82 \mu \mathrm{L}, 0.98 \mathrm{mmol})$ were dissolved in $6 \mathrm{~mL} \mathrm{CH}_{2} \mathrm{Cl}_{2} / \mathrm{CH}_{3} \mathrm{OH}(\mathrm{v}: \mathrm{v}=1: 1)$. The mixture was stirred at room temperature for $24 \mathrm{~h}$. After the solvents removed under reduced pressure, the residue was purified by column chromatograph $\left(\mathrm{CH}_{2} \mathrm{Cl}_{2}\right.$ : petroleum ether $=1: 2, \mathrm{v} / \mathrm{v})$ to afford an orange solid (153 mg, yield 21\%). Mp: 132$134{ }^{\circ} \mathrm{C} ;{ }^{1} \mathrm{H} \mathrm{NMR}\left(\mathrm{CDCl}_{3}, 400 \mathrm{MHz}\right), \delta(\mathrm{ppm}): 8.20(\mathrm{~d}, J=15.2 \mathrm{~Hz}, 1 \mathrm{H}), 8.12(\mathrm{~m}, 2 \mathrm{H})$, $7.77(\mathrm{~s}, 1 \mathrm{H}), 7.62(\mathrm{~d}, J=15.2 \mathrm{~Hz}, 1 \mathrm{H}), 7.32(\mathrm{~d}, J=9.2 \mathrm{~Hz}, 1 \mathrm{H}), 7.15(\mathrm{~m}, 2 \mathrm{H}), 6.60(\mathrm{dd}$, $J=2.4 \mathrm{~Hz}, 8.8 \mathrm{~Hz}, 1 \mathrm{H}), 6.49(\mathrm{~d}, J=2.4 \mathrm{~Hz}, 1 \mathrm{H}), 3.44(\mathrm{~m}, 4 \mathrm{H}), 1.23(\mathrm{~m}, 6 \mathrm{H}) ;{ }^{13} \mathrm{C} \mathrm{NMR}$ $\left(\mathrm{CDCl}_{3}, 100 \mathrm{MHz}\right), \delta$ (ppm): 189.0, 166.8, 164.3, 160.2, 156.6, 151.9, 146.4, 140.1, 134.8, 134.7, 131.2, 131.1, 130.0, 122.4, 115.7, 115.4, 114.8, 109.6, 108.9, 96.9, 45.0, 12.5; MS (ESI) m/z $365.99[\mathrm{M}+\mathrm{H}]^{+}$; Elemental analysis calcd (\%) for $\mathrm{C}_{22} \mathrm{H}_{20} \mathrm{FNO}_{3}$ : C 72.31; H 5.52; N 3.83; found C 71.96, H 5.54, N 3.81 .

\section{Synthesis of compound $3 \mathrm{f}$}

Compound 4 (500 mg, $2.04 \mathrm{mmol})$, 4-Chloroacetophenone 6f (282 mg, $2.04 \mathrm{mmol})$, and pyrrolidine $(82 \mu \mathrm{L}, 0.98 \mathrm{mmol})$ in $6 \mathrm{~mL} \mathrm{CH}_{2} \mathrm{Cl}_{2} / \mathrm{CH}_{3} \mathrm{OH}(\mathrm{v}: \mathrm{v}=1: 1)$. The mixture was stirred at room temperature for $24 \mathrm{~h}$. After the solvents removed under reduced pressure, the residue was purified by column chromatograph $\left(\mathrm{CH}_{2} \mathrm{Cl}_{2}\right.$ : petroleum ether $=1: 2, \mathrm{v} / \mathrm{v})$ to afford an orange solid $(153 \mathrm{mg}$, yield $21 \%)$. Mp: 137-140 ${ }^{\circ} \mathrm{C} ;{ }^{1} \mathrm{H} \mathrm{NMR}$ $\left(\mathrm{CDCl}_{3}, 400 \mathrm{MHz}\right), \delta(\mathrm{ppm}): 8.21(\mathrm{~d}, J=15.2 \mathrm{~Hz}, 1 \mathrm{H}), 8.04(\mathrm{~d}, J=8 \mathrm{~Hz}, 2 \mathrm{H}), 7.79$ (s, $1 \mathrm{H}), 7.65(\mathrm{~d}, J=15.2 \mathrm{~Hz}, 1 \mathrm{H}), 7.47$ (d, $J=8 \mathrm{~Hz}, 1 \mathrm{H}), 7.34$ (d, $J=8.8 \mathrm{~Hz}, 1 \mathrm{H}), 6.63$ 
$(\mathrm{dd}, J=2.4 \mathrm{~Hz}, 8.8 \mathrm{~Hz}, 1 \mathrm{H}), 6.51(\mathrm{~d}, J=2.4 \mathrm{~Hz}, 1 \mathrm{H}), 3.47(\mathrm{~m}, 4 \mathrm{H}), 1.25(\mathrm{~m}, 6 \mathrm{H}) ;{ }^{13} \mathrm{C}$ $\mathrm{NMR}\left(\mathrm{CDCl}_{3}, 100 \mathrm{MHz}\right), \delta$ (ppm): 189.4, 160.2, 156.6, 152.0, 146.6, 140.4, 138.9, 136.7, 130.0, 128.8, 122.3, 114.7, 109.6, 108.9, 96.9, 45.1, 12.5; Elemental analysis calcd (\%) for $\mathrm{C}_{22} \mathrm{H}_{20} \mathrm{ClNO}_{3}$ : C 69.20; H 5.28; N 3.67; found C 68.89, H 5.31, N 3.65.

\section{Synthesis of compound 7}

Under a nitrogen atmosphere, 1,2-dibromoethane (4.346 g, $23.13 \mathrm{mmol}$ ) was added to a solution of triphenylphosphine $(3 \mathrm{~g}, 11.57 \mathrm{mmol})$ in methylbenzene $(5 \mathrm{~mL})$. The mixture was heated at reflux for 3 hours. After cooling to room temperature, the white solid was precipitated and collected. (3.637 g, yield 69.83\%). Mp: $210-215{ }^{\circ} \mathrm{C} ;{ }^{1} \mathrm{H} \mathrm{NMR}$ (400 MHz, $\left.\mathrm{CDCl}_{3}\right) \delta(\mathrm{ppm}): 7.81(\mathrm{~m}, 15 \mathrm{H}), 4.17(\mathrm{~m}, 2 \mathrm{H}), 2.81(\mathrm{~m}, 2 \mathrm{H}) ; \mathrm{MS}(\mathrm{ESI}) \mathrm{m} / \mathrm{z}$ $370.0[\mathrm{M}]^{+}$.

\section{Synthesis of compound 8}

Under a nitrogen atmosphere, compound $7(2.76 \mathrm{~g}, 6.13 \mathrm{mmol})$ and potassium thioacetate $(1.4 \mathrm{~g}, 12.26 \mathrm{mmol})$ were dissolved in $\mathrm{H}_{2} \mathrm{O} /$ ethanol $(1: 2 \mathrm{v} / \mathrm{v} ; 27 \mathrm{~mL})$. The mixture was stirred at room temperature for 9 hours. After that, add water to the solution and mix well, and the organic phase was extracted with $\mathrm{CH}_{2} \mathrm{Cl}_{2}$. Then, the volatiles were removed under reduced pressure and a white solid was obtained (1.637 g, yield 59.96\%). Mp: $223-227{ }^{\circ} \mathrm{C}$; ${ }^{1} \mathrm{H}$ NMR (400 MHz, $\left.\mathrm{CDCl}_{3}\right) \delta$ (ppm): 7.83 (m, 9H), 7.71 $(\mathrm{m}, 6 \mathrm{H}), 3.90(\mathrm{~m}, 2 \mathrm{H}), 2.94(\mathrm{t}, J=6.8 \mathrm{~Hz}, 2 \mathrm{H}), 2.21(\mathrm{~s}, 3 \mathrm{H}), 2.05(\mathrm{~m}, 2 \mathrm{H}), 1.69(\mathrm{~m}$, 2H), MS (ESI) m/z: $245.1[\mathrm{M}]^{+}$.

\section{Synthesis of compound 9}

Under a nitrogen atmosphere, compound 8 (0.674 g, $1.51 \mathrm{mmol})$ was dissolved in 10 $\mathrm{mL}$ methanol. Subsequently, $1 \mathrm{~mL} \mathrm{HCl}$ was added. The resulting mixture was heated at reflux for 20 hours. After that, add water to the solution and mix well, the organic phase was extracted with $\mathrm{CH}_{2} \mathrm{Cl}_{2}$. The volatiles were removed under reduced pressure to get the white solid, then, the resulting white solid was collected by filtration and was further purified by recrystallization in anhydrous ethanol to afford white solid $(0.314 \mathrm{~g}$, yield 57.83\%). Mp: 57-61 ${ }^{\circ} \mathrm{C} ;{ }^{1} \mathrm{H}$ NMR (400 MHz, $\left.\mathrm{CDCl}_{3}\right) \delta$ (ppm): 7.99 (m, 9H), 7.69 (m, $6 \mathrm{H}), 4.18(\mathrm{~m}, 2 \mathrm{H}), 3.68(\mathrm{~m}, 2 \mathrm{H}), 1.21(\mathrm{~s}, 1 \mathrm{H}), \mathrm{MS}(\mathrm{m} / \mathrm{z}): 323.41[\mathrm{M}]^{+}$.

\section{Synthesis of compound $\mathrm{Hy}-1$}

Compound $1(100 \mathrm{mg}, 0.206 \mathrm{mmol})$ and butanethiol $(22 \mu \mathrm{L}, 0.206 \mathrm{mmol})$ were dissolved in $\mathrm{CHCl}_{3}$. The mixture was heated at reflux for 24 hours. After that, the volatiles were removed under reduced pressure. The resulting residue was further purified by column chromatography over silica gel (acetone: petroleum ether: $\mathrm{CH}_{3} \mathrm{OH}$ $=5: 15: 1, \mathrm{v} / \mathrm{v} / \mathrm{v}$ ) to afford compound $\mathbf{H y}-\mathbf{1}$ as an orange solid (34 mg, yield 19.6\%). Mp: 213-217 ${ }^{\circ} \mathrm{C} ;{ }^{1} \mathrm{H}$ NMR $\left(400 \mathrm{MHz}, \mathrm{CDCl}_{3}\right) \delta(\mathrm{ppm}): 8.43(\mathrm{~s}, 1 \mathrm{H}), 7.73(\mathrm{~s}, 1 \mathrm{H}), 7.38(\mathrm{~d}, J$ $=8.8 \mathrm{~Hz}, 1 \mathrm{H}), 7.29(\mathrm{~d}, J=3.2 \mathrm{~Hz}, 1 \mathrm{H}), 6.62(\mathrm{dd}, J=2.4 \mathrm{~Hz}, 8.8 \mathrm{~Hz}, 1 \mathrm{H}), 6.57(\mathrm{dd}, J$ $=2.4 \mathrm{~Hz}, 8.8 \mathrm{~Hz}, 1 \mathrm{H}), 6.50(\mathrm{~d}, J=2.4 \mathrm{~Hz}, 1 \mathrm{H}), 6.47(\mathrm{~d}, J=2.4 \mathrm{~Hz}, 1 \mathrm{H}), 4.69(\mathrm{t}, J=$ $7.2 \mathrm{~Hz}, 1 \mathrm{H}), 3.75(\mathrm{~m}, 2 \mathrm{H}), 3.44(\mathrm{~m}, 8 \mathrm{H}), 2.59(\mathrm{~m}, 2 \mathrm{H}), 1.59(\mathrm{~m}, 2 \mathrm{H}), 1.39(\mathrm{~m}, 2 \mathrm{H}), 1.22$ $(\mathrm{m}, 12 \mathrm{H}), 0.89$ (t, $J=7.6 \mathrm{~Hz}, 3 \mathrm{H}) ;{ }^{13} \mathrm{C} \mathrm{NMR}\left(100 \mathrm{MHz}, \mathrm{CDCl}_{3}\right) \delta(\mathrm{ppm}): 194.3,161.9$, 
160.7, 158.7, 155.7, 153.1, 150.2, 148.3, 139.4, 131.9, 128.7, 122.5, 115.7, 109.9, 108.7, 108.6, 108.3, 97.2, 96.5, 47.1, 45.2, 44.8, 39.1, 31.7, 31.5, 22.1, 13.7, 12.5; MS (ESI) $\mathrm{m} / \mathrm{z} 809.56$ [M]; Elemental analysis calcd (\%) for $\mathrm{C}_{33} \mathrm{H}_{40} \mathrm{~N}_{2} \mathrm{O}_{5} \mathrm{~S}: \mathrm{C} 68.72 ; \mathrm{H} 6.99 ; \mathrm{N}$ 4.86; found C 68.40, H 7.02, N 4.84.

\section{Synthesis of compound $\mathrm{Hy}-2$}

Compound 1d (100 mg, $0.239 \mathrm{mmol})$ and compound 9 (86 mg, $0.239 \mathrm{mmol})$ were dissolved in $\mathrm{CHCl}_{3}$. The mixture was heated at reflux for 23 hours. After that, the volatiles were removed under reduced pressure. The resulting residue was further purified by column chromatography over silica gel $\left(\mathrm{CH}_{2} \mathrm{Cl}_{2}\right.$ : petroleum ether: $\mathrm{CH}_{3} \mathrm{OH}$ $=10: 10: 1, \mathrm{v} / \mathrm{v} / \mathrm{v})$ to afford compound $\mathbf{H y}-\mathbf{2}$ as a rufous solid (21 mg, yield $12.6 \%)$. Mp: 212-216 ${ }^{\circ} \mathrm{C} ;{ }^{1} \mathrm{H}$ NMR (400 MHz, Methanol- $\left.d_{4}\right) \delta(\mathrm{ppm}): 7.76(\mathrm{~m}, 19 \mathrm{H}), 7.32(\mathrm{~d}, J=8.8$ $\mathrm{Hz}, 1 \mathrm{H}), 6.68(\mathrm{~m}, 2 \mathrm{H}), 6.50(\mathrm{~d}, J=2.4 \mathrm{~Hz}, 1 \mathrm{H}), 4.63(\mathrm{~m}, 1 \mathrm{H}), 3.79(\mathrm{~m}, 2 \mathrm{H}), 3.48(\mathrm{~m}$, $8 \mathrm{H}), 3.41(\mathrm{~m}, 2 \mathrm{H}), 2.88(\mathrm{~m}, 2 \mathrm{H}), 1.20(\mathrm{~m}, 12 \mathrm{H}) ;{ }^{13} \mathrm{C}$ NMR (100 MHz, Methanol- $\left.d_{4}\right) \delta$ (ppm): 195.4, 162.5, 155.7, 151.8, 140.4, 135.0, 134.9, 133.5, 133.4, 130.7, 130.2, 130.1, 123.5, 120.1 , 118.4, 117.5, 110.1, 109.3, 96.2, 44.3, 44.1, 41.6, 40.2, 11.4, 11.3; MS (ESI) m/z $741.41[\mathrm{M}]^{+}$; Elemental analysis calcd (\%) for $\mathrm{C}_{46} \mathrm{H}_{50} \mathrm{~N}_{2} \mathrm{O}_{3} \mathrm{PS}^{+}$: C 74.47; H 6.79; N 3.78; found C 74.16, H 6.81, N 3.76.

\section{Detection of $\mathrm{ClO}^{-}$in aqueous solution}

A stock solution of probe $\mathbf{H y - 2}\left(5 \times 10^{-4} \mathrm{M}\right)$ was prepared in methanol. Stock solution of $\mathrm{ClO}^{-}\left(5 \times 10^{-3} \mathrm{M}\right)$ in water were prepared from $5.2 \% \mathrm{NaClO}$. The sensing reaction of probe $\mathbf{H y}-2(5 \mu \mathrm{M})$ with various amounts of $\mathrm{ClO}^{-}$was carried out in $50 \mathrm{mM}$ potassium phosphate buffer / methanol (4: $1 \mathrm{v} / \mathrm{v}, \mathrm{pH}$ 7.4) for $30 \mathrm{mins}$ at room temperature. Subsequently, the fluorescence spectra of the solutions were measured.

\section{Detection of ${ }^{1} \mathrm{O}_{2}$ in aqueous solution}

The ${ }^{1} \mathrm{O}_{2}$ was generated from a $\mathrm{Na}_{2} \mathrm{MoO}_{4} / \mathrm{H}_{2} \mathrm{O}_{2}$ system ${ }^{1-2}$ and photoirradiation of photosensitizer tetra-(N-methyl-4-pyridyl)porphyrin (TMPyP4), ${ }^{3}$ respectively. The detailed experimental procedures are as follows:

(1) The reaction of the probe $\mathbf{H y}-2$ with ${ }^{1} \mathrm{O}_{2}$ generated from a $\mathrm{Na}_{2} \mathrm{MoO}_{4} / \mathrm{H}_{2} \mathrm{O}_{2}$ system was performed in $50 \mathrm{mM}$ carbonate buffer / methanol (4: $1 \mathrm{v} / \mathrm{v}, \mathrm{pH} 10.5)$. Various concentrations of $\mathrm{H}_{2} \mathrm{O}_{2}$ solutions were added to the buffer solution containing $50 \mu \mathrm{M}$ of the probe $\mathbf{H y}-\mathbf{2}$ and $1.0 \mathrm{mM}$ of $\mathrm{Na}_{2} \mathrm{MoO}_{4}$. After stirring for 30 mins at room temperature, the solutions were 10 -fold diluted with $50 \mathrm{mM}$ potassium phosphate buffer / methanol (4:1 v/v, pH 7.4). Then, the fluorescence emission spectra of the solutions were measured.

(2) The reaction of the probe $\mathbf{H y}-2$ with ${ }^{1} \mathrm{O}_{2}$ generated from photoirradiation of photosensitizer TMPyP4 was performed in $50 \mathrm{mM}$ potassium phosphate buffer / methanol (4: $1 \mathrm{v} / \mathrm{v}, \mathrm{pH}$ 7.4). The probe Hy-2 $(5 \mu \mathrm{M})$ and TMPyP4 $(5 \mu \mathrm{M})$ were codissolved in the buffer solution $(5 \mathrm{~mL})$. A white LED lamp $\left(150 \mathrm{~mW} / \mathrm{cm}^{2}\right)$ was used as a light source to continuously irradiate TMPyP4. Then, the fluorescence emission spectra of the solutions were measured at different time intervals. 


\section{Reactions of probe Hy-2 with various other ROS, biological molecules, and metal ions}

Solutions of the various other reactive oxygen species (ROS), biological molecules, and metal ions were prepared from $30 \% \mathrm{H}_{2} \mathrm{O}_{2}, \mathrm{GSH}$, Cys, $\mathrm{MgCl}_{2} \cdot 6 \mathrm{H}_{2} \mathrm{O}, \mathrm{FeSO}_{4} \cdot 7 \mathrm{H}_{2} \mathrm{O}$, $\mathrm{Fe}\left(\mathrm{NO}_{3}\right)_{3} \cdot 9 \mathrm{H}_{2} \mathrm{O}, \mathrm{Zn}\left(\mathrm{NO}_{3}\right)_{2} \cdot 6 \mathrm{H}_{2} \mathrm{O}$ respectively. Hydroxyl radical was generated by Fenton reaction. ${ }^{4}$ Nitric oxide was generated from SNP (sodium nitroferricyanide (III) dihydrate) ${ }^{5-6}$ All the reactions were carried out in $50 \mathrm{mM}$ potassium phosphate buffer / methanol (4: $1 \mathrm{v} / \mathrm{v}, \mathrm{pH} 7.4)$. Probe Hy-2 $(5 \mu \mathrm{M})$ was incubated with various species for $30 \mathrm{mins}$ in the buffer solution at room temperature. Subsequently, the fluorescence emission spectra of the solutions were measured.

\section{Determination of the fluorescence quantum yield}

Fluorescence quantum yields were determined using solutions of rhodamine $6 \mathrm{G}\left(\Phi_{\mathrm{F}}=\right.$ 0.94 in ethanol) as a standard. ${ }^{7}$ The quantum yield was calculated using the following equation: ${ }^{8-10}$

$$
\Phi_{\mathrm{F}(\mathrm{X})}=\Phi_{\mathrm{F}(\mathrm{S})}\left(\mathrm{As}_{\mathrm{S}} \mathrm{F}_{\mathrm{XX}} / \mathrm{AXF}_{\mathrm{S}}\right)\left(\mathrm{n}_{\mathrm{X}} / \mathrm{ns}_{\mathrm{S}}\right)^{2}
$$

Where $\Phi \mathrm{F}$ is the fluorescence quantum yield, $A$ is the absorbance at the excitation wavelength, $F$ is the area under the corrected emission curve, and $n$ is the refractive index of the solvents used. Subscripts $\mathrm{S}$ and $\mathrm{X}$ refer to the standard and to the unknown, respectively.

\section{Determination of the detection limit}

The detection limit was calculated according to a method used in the literature. ${ }^{11}$ The fluorescence emission spectrum of probe $\mathbf{H y - 2}$ was measured five times and the standard deviation of a blank measurement was achieved. The fluorescence emission (I526) was plotted as a concentration of $\mathrm{ClO}^{-}$or the fluorescence emission ( $\mathrm{I}_{597}$ ) was plotted a concentration of ${ }^{1} \mathrm{O}_{2}$. The detection limit was calculated using the following equation:

$$
\text { Detection limit }=3 \sigma / \mathrm{k}
$$

Where $\sigma$ is the standard deviation of blank measurement, $\mathrm{k}$ is the slope between the fluorescence emission ( $\mathrm{I}_{526}$ ) versus $\mathrm{ClO}^{-}$concentration or the slope between the fluorescence emission ( $\mathrm{I}_{597}$ ) versus ${ }^{1} \mathrm{O}_{2}$ concentration.

\section{Cell culture}

Cultures of HepG2 cells: HepG2 cells were seeded in 35-mm glass-bottomed culture dishes in Dulbecco's modified Eagle's medium (DMEM) supplemented with 10\% fetal bovine serum and incubated for 24 hours.

Cultures of RAW 264.7 cells: The RAW 264.7 line was obtained from the school of medicine at Jiangsu University. The cells were seeded in 35-mm glass-bottomed culture 
dishes in Dulbecco's modified Eagle's medium (DMEM) supplemented with 10\% horse serum bovine serum and incubated for 24 hours.

\section{Fluorescence imaging in live cells}

Colocalization experiments: live HepG2 cells in 35-mm glass bottom culture dishes were stained with $1 \mu \mathrm{M}$ of probe $\mathbf{H y - 2}$ for 20 mins. Then, the cells were further stained with $0.5 \mu \mathrm{M}$ MitoTracker Orange for another 20 mins. Fluorescent images were acquired on a Leica TCS SP5 II laser confocal scanning microscope using an objective lens (×40). The blue channel of $\mathbf{H y - 2}$ involved fluorescence was recorded at 450-490 $\mathrm{nm}$ with excitation at $405 \mathrm{~nm}$. The green Channel was recorded at 500-550 nm with excitation at $476 \mathrm{~nm}$. The red channel of MitoTracker Orange involved fluorescence was recorded at 575-650 $\mathrm{nm}$ with excitation at $543 \mathrm{~nm}$.

Fluorescence imaging of exogenous $\mathrm{ClO}^{-}$in Hep 2 cells: live HepG2 cells in 35-mm glass bottom culture dishes were stained with $1 \mu \mathrm{M} \mathbf{H y}-2$ for 20 mins. Then, the cells were further treated with different concentrations of $\mathrm{ClO}^{-}(0,40,80 \mu \mathrm{M})$ for 20 mins. For a control experiment, live HepG2 cells stained with $1 \mu \mathrm{M}$ probe $\mathbf{H y - 2}$ for 20 mins. After that, the cells were incubated with NAC (1 mM) for 30 mins. Then, the cells were treated with $\mathrm{ClO}^{-}(80 \mu \mathrm{M})$ for 20 mins. Fluorescent images were acquired on a Leica TCS SP5 II laser confocal scanning microscope with an objective lens $(\times 40)$. The blue channel was recorded at 450-490 nm with excitation at $405 \mathrm{~nm}$. The green channel was recorded at 500-550 $\mathrm{nm}$ with excitation at $476 \mathrm{~nm}$. The red channel was recorded at $575-650 \mathrm{~nm}$ with excitation at $543 \mathrm{~nm}$.

Fluorescence imaging of photoirradiation-induced ${ }^{1} \mathrm{O}_{2}$ in HepG2 cells: live HepG2 cells were incubated with 5-ALA $\left(150 \mu \mathrm{g} \mathrm{ml}{ }^{-1}\right)$ for 12 hours to biosynthesize photosensitizer protoporphyrin IX (PpIX). The cells were further stained with probe Hy-2 $(1 \mu \mathrm{M})$ for 20 mins. After that, the selected cell region was continuously irradiated with $405 \mathrm{~nm}$ laser (20\% laser power) to generate ${ }^{1} \mathrm{O}_{2}$. Concurrently, the fluorescent images were acquired at different time interval on a Leica TCS SP5 II laser confocal scanning microscope with an objective lens $(\times 40)$.

For a control experiment, live HepG2 cells were incubated with 5-ALA (150 $\mu \mathrm{g} \mathrm{ml}^{-}$ $\left.{ }^{1}\right)$ for 12 hours to biosynthesize photosensitizer protoporphyrin IX (PpIX). After stained with probe Hy-2 $(1 \mu \mathrm{M})$ for 20 mins, the cells were treated with His $(2 \mathrm{mM})$ for 30 mins. Next, the selected cell region was continuously irradiated with $405 \mathrm{~nm}$ laser $(20 \%$ laser power). Concurrently, the fluorescent images were acquired at different time interval on a Leica TCS SP5 II laser confocal scanning microscope with an objective lens $(\times 40)$. The blue channel was recorded at 450-490 nm with excitation at $405 \mathrm{~nm}$. The green channel was recorded at 500-550 nm with excitation at $476 \mathrm{~nm}$. The red channel was recorded at $575-650 \mathrm{~nm}$ with excitation at $543 \mathrm{~nm}$.

Fluorescence imaging of endogenous $\mathrm{ClO}^{-}$and ${ }^{1} \mathrm{O}_{2}$ in $\mathrm{RAW} 264.7$ cells: live RAW 264.7 cells in $35-\mathrm{mm}$ glass bottom culture dishes were stained with $1 \mu \mathrm{M} \mathrm{Hy-2}$ for 20 mins. Then, the cells were stimulated with growing dosage of PMA $(0,5,20 \mu \mathrm{M})$ for 
30 mins. After that, fluorescent images were acquired on a Leica TCS SP5 II laser confocal scanning microscope with an objective lens $(\times 40)$. The blue channel was recorded at 450-490 nm with excitation at $405 \mathrm{~nm}$. The green channel was recorded at $500-550 \mathrm{~nm}$ with excitation at $476 \mathrm{~nm}$. The red channel was recorded at 575-650 nm with excitation at $543 \mathrm{~nm}$.

\section{Computational details}

Calculations were performed using the Gaussian 09 program. ${ }^{12}$ Becke's threeparameter and Lee-Yang-Parr hybrid functional (B3LYP) $)^{13-15}$ and a $6-31+G(d, p)$ basis set $^{16}$ were used. The geometries were optimized in water using the polarizable continuum model (PCM) to allow for implicit solvent incorporation. ${ }^{17-18}$ The ground state $\left(\mathrm{S}_{0}\right)$ geometries of $\mathbf{H y - 1 , 1 , 2}$, and 3a-3f were optimized using density functional theory (DFT). The lowest singlet excited state (S1) geometries of 3a-3f were optimized using time-dependent density functional theory (TDDFT) calculations.

The rotational barriers of phenyl group around $\mathrm{C}^{19}-\mathrm{C}^{20}$ bond in $\mathbf{3 a - 3 f}$ can be estimated from the calculated potential energy scans at DFT-B3LYP/6-31G(d,p)/ level using Gaussian 09. ${ }^{19-21}$ The potential energy scans were calculated by varying the dihedral angles between the coumarin ring and phenyl ring around the $\mathrm{C}^{19}-\mathrm{C}^{20}$ bond from $0^{\circ}$ to $360^{\circ}$ in $10^{\circ}$ increments. The results of the scans are shown in Figure $2 \mathrm{~b}$. 

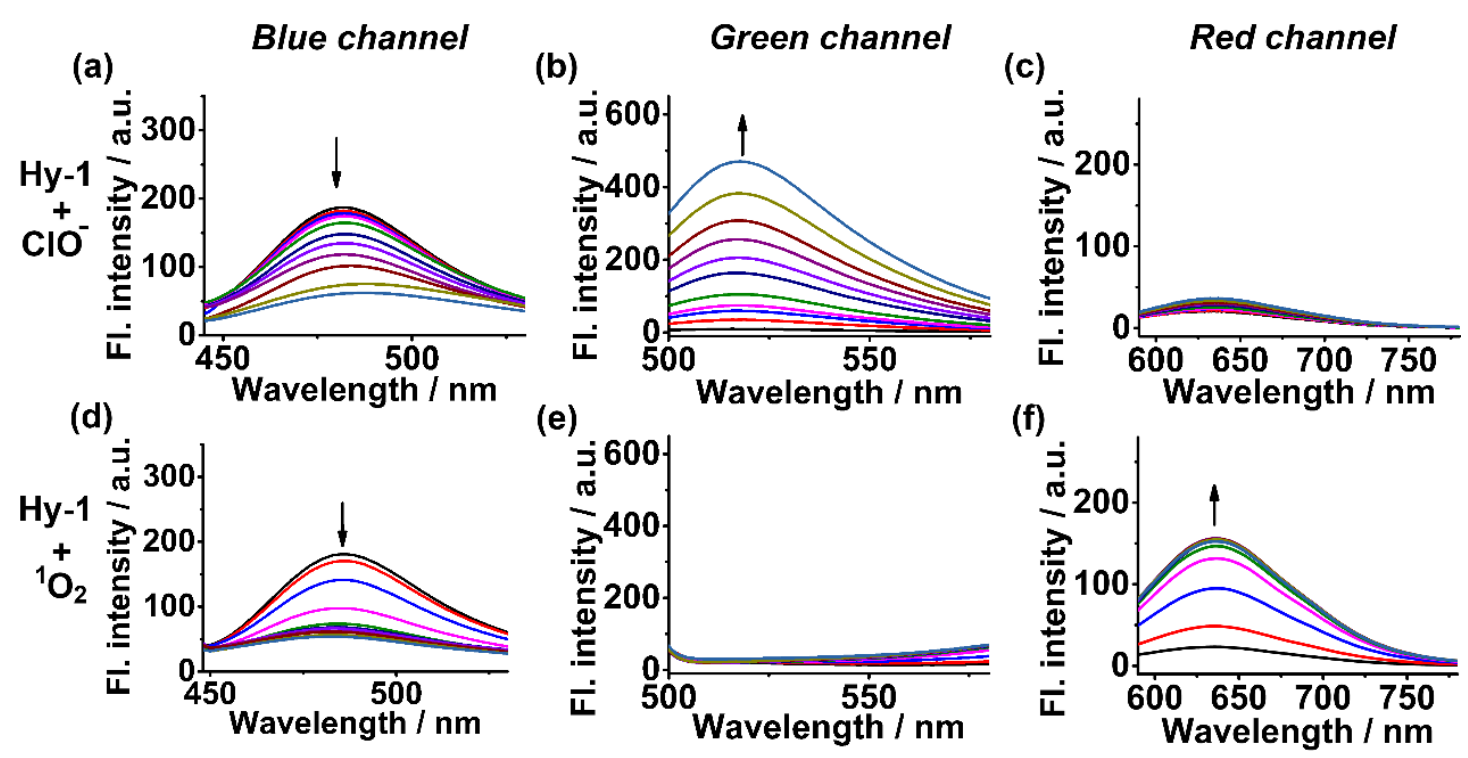

Figure S1. (a-c) The fluorescence spectra of Hy-1 $(5 \mu \mathrm{M})$ upon addition of $\mathrm{ClO}^{-}(0-$ $500 \mu \mathrm{M})$ in aqueous buffer / methanol $(1: 4 \mathrm{v} / \mathrm{v})$. (d-f) The fluorescence spectra of Hy$1(5 \mu \mathrm{M})$ upon addition of ${ }^{1} \mathrm{O}_{2}(0-1.8 \mathrm{mM})$ in aqueous buffer / methanol $(1: 4 \mathrm{v} / \mathrm{v})$. The ${ }^{1} \mathrm{O}_{2}$ was generated from a $\mathrm{Na}_{2} \mathrm{MoO}_{4} / \mathrm{H}_{2} \mathrm{O}_{2}$ system. Excitation at $420 \mathrm{~nm}$ for (a) and (d); $480 \mathrm{~nm}$ for (b) and (e); and $530 \mathrm{~nm}$ for (c) and (f).
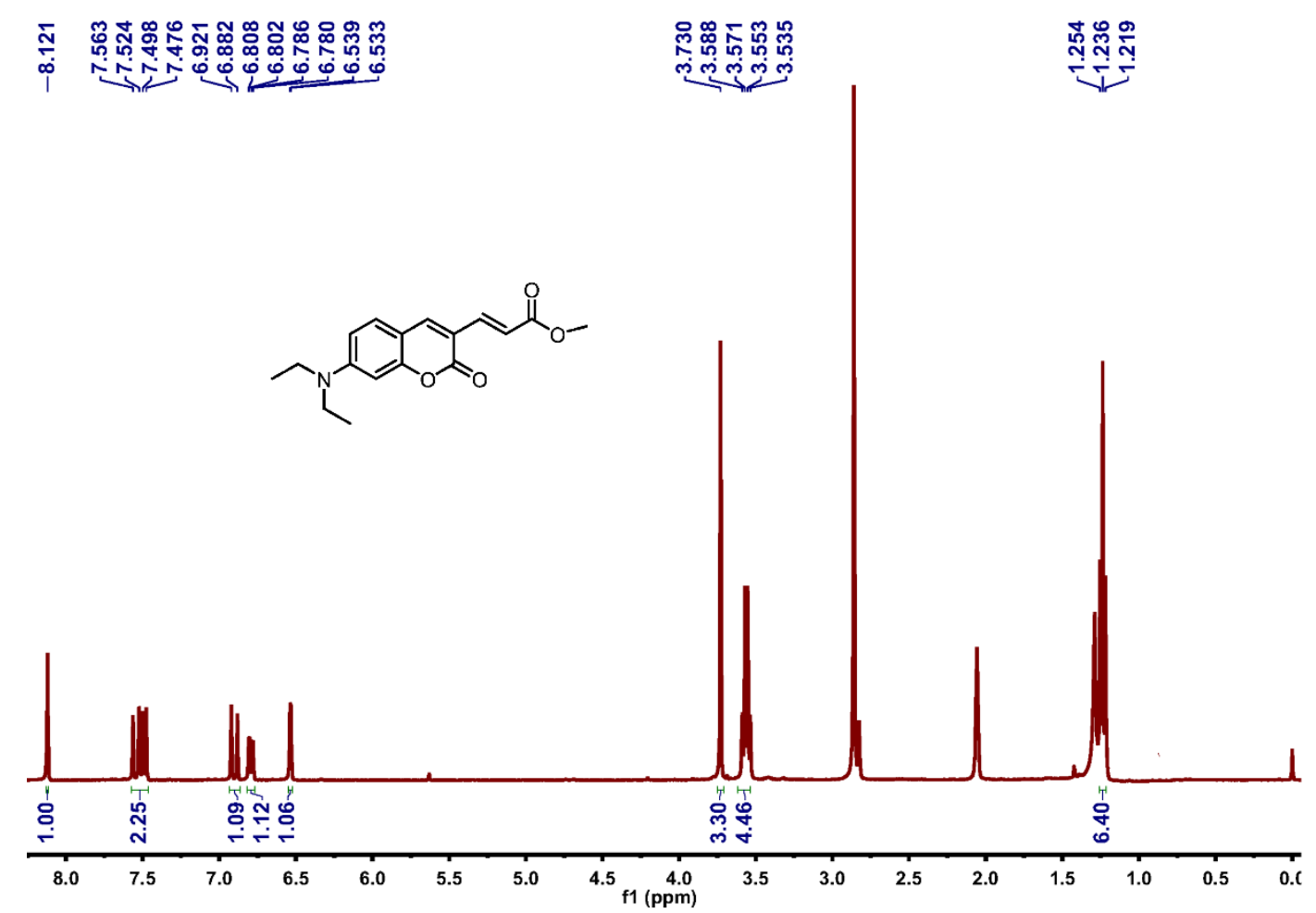

Figure S2. The ${ }^{1} \mathrm{H}$ NMR spectra for the isolated product of $\mathbf{H y - 1}$ with $\mathrm{ClO}^{-}$. 




Figure S3. The ${ }^{13} \mathrm{C}$ NMR spectra for the isolated product of $\mathbf{H y - 1}$ with $\mathrm{ClO}^{-}$.

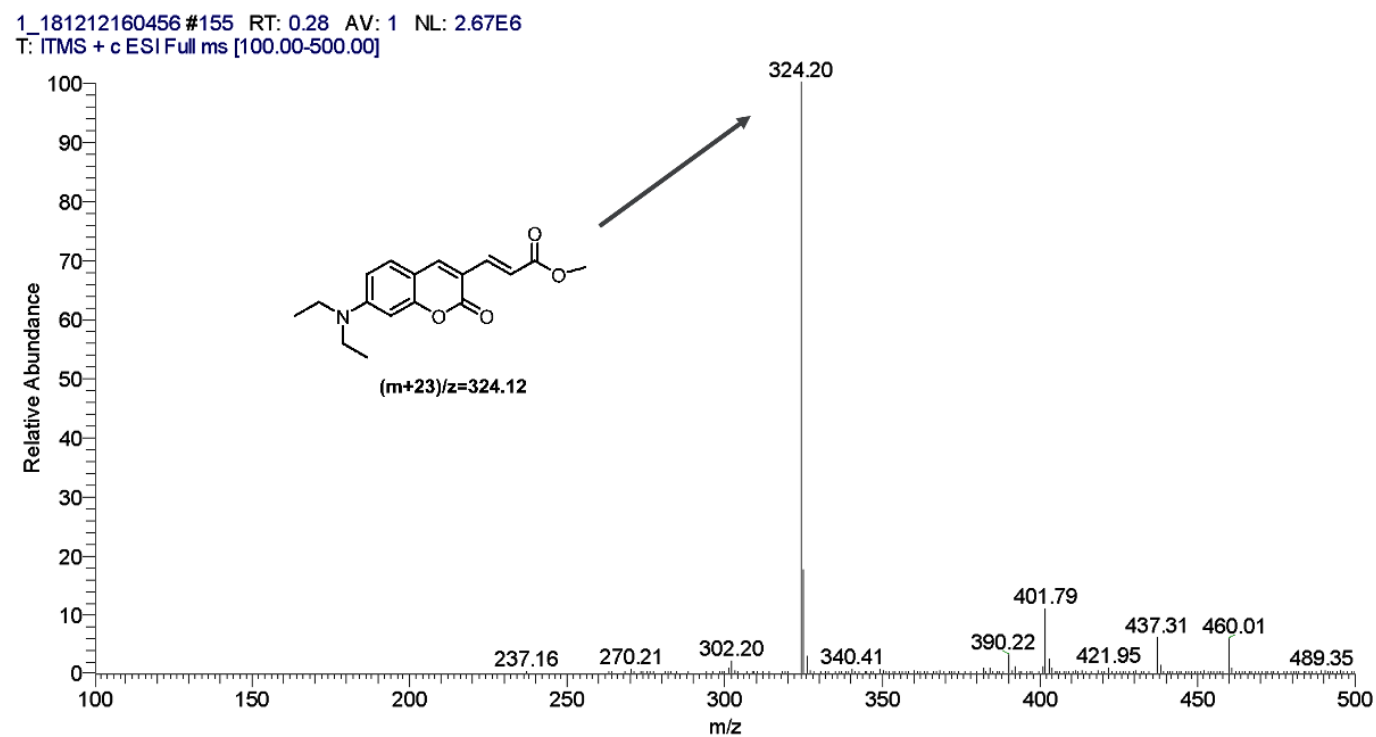

Figure S4. The ESI-Ms spectra for the isolated product of $\mathbf{H y - 1}$ with $\mathrm{ClO}^{-}$. 
Table S1. Crystallographic parameters for compound 2.

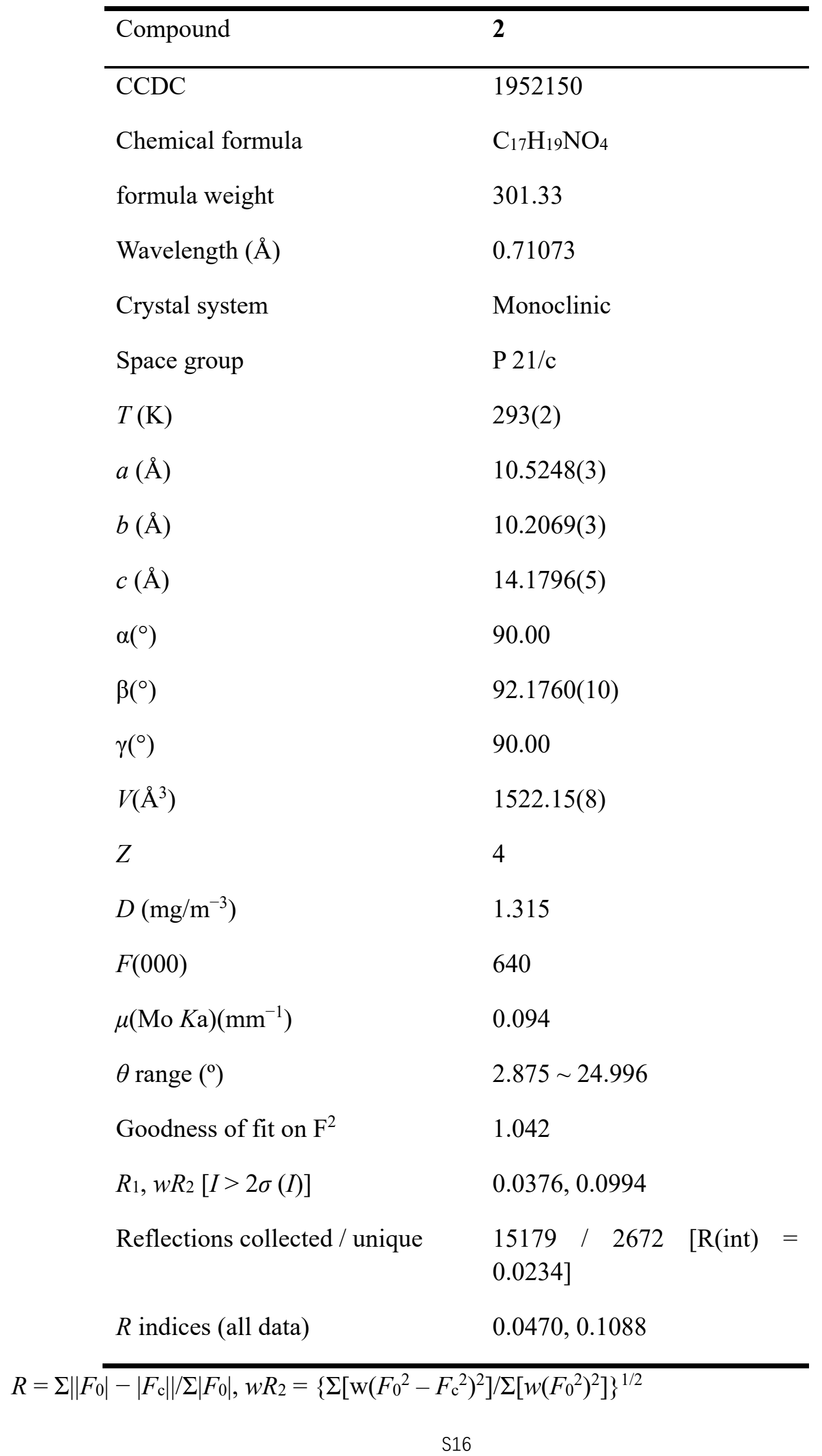


(a)

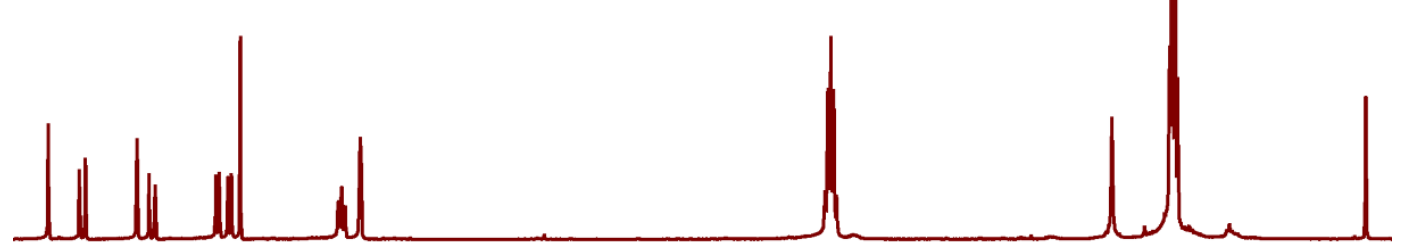

(b)

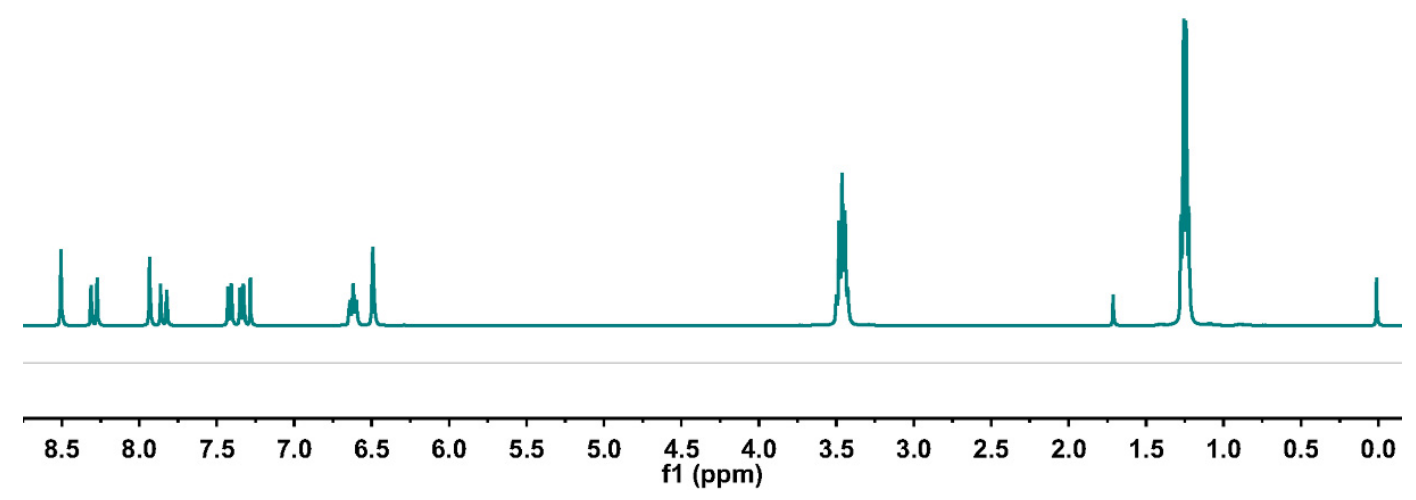

Figure S5. (a) The ${ }^{1} \mathrm{H}$ NMR spectra for the isolated product of $\mathbf{H y}-\mathbf{1}$ with ${ }^{1} \mathrm{O}_{2}$; (b) the standard ${ }^{1} \mathrm{H}$ NMR spectra for compound $\mathbf{1}$. The solvent for ${ }^{1} \mathrm{H}$ NMR spectra was $\mathrm{CDCl}_{3}$.



Figure S6. The ESI-HRMS spectra for the isolated product of $\mathbf{H y}-\mathbf{1}$ with ${ }^{1} \mathrm{O}_{2}$. 

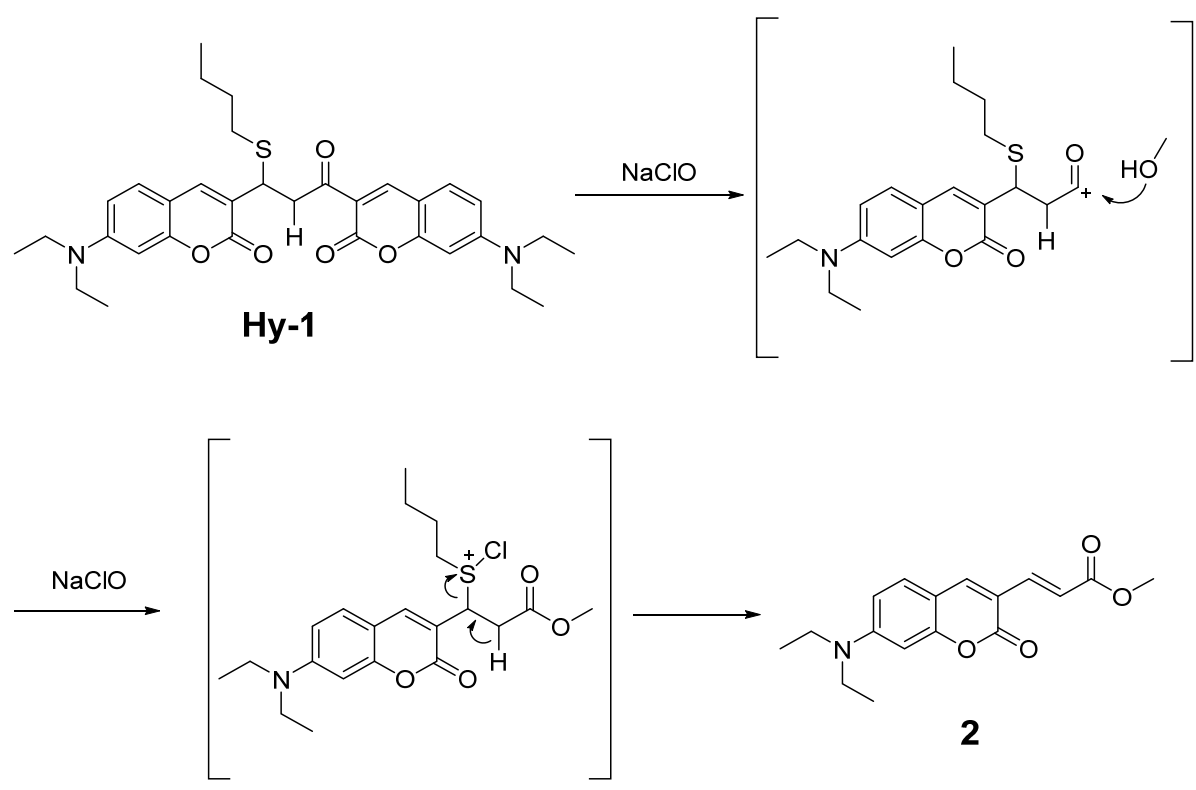

Scheme S5. A plausible mechanism for $\mathbf{H y - 1}$ reaction with $\mathrm{ClO}^{-}$.
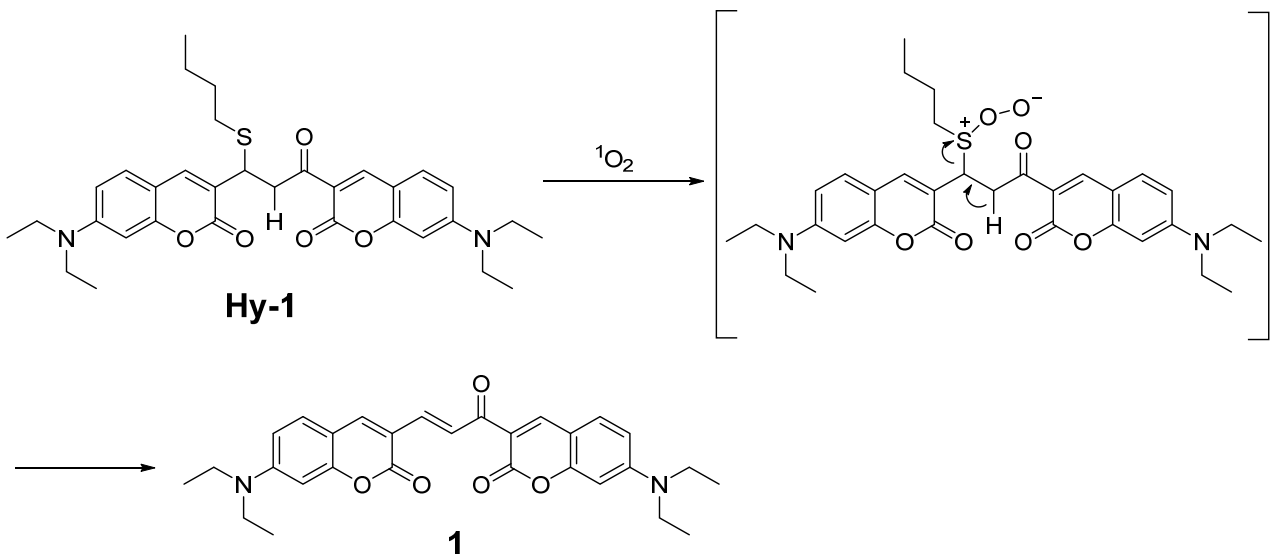

Scheme S6. A plausible mechanism for $\mathbf{H y}-\mathbf{1}$ reaction with ${ }^{1} \mathrm{O}_{2}$. 
(a)

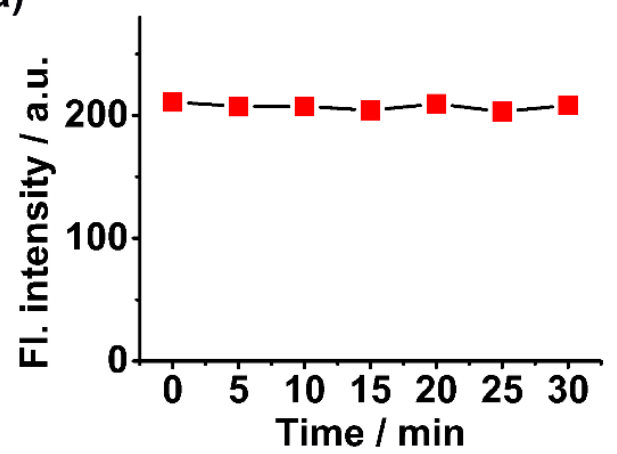

(b)

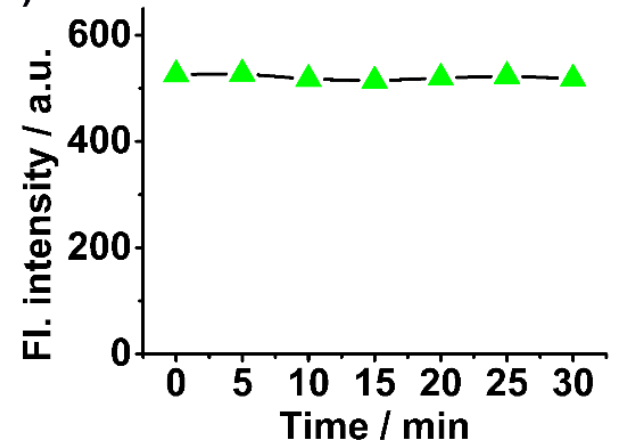

Figure S7. The photostability of compound 1 and $\mathbf{2}$. Compound $\mathbf{1}(5 \mu \mathrm{M})$ and $\mathbf{2}(5 \mu \mathrm{M})$ were continuously irradiated with a white LED lamp $\left(150 \mathrm{~mW} / \mathrm{cm}^{2}\right)$ in aqueous buffer / methanol $(1: 4 \mathrm{v} / \mathrm{v})$, and the fluorescence intensities of (a) compound $1\left(\lambda_{\mathrm{em}}=637 \mathrm{~nm}\right.$; $\left.\lambda_{\mathrm{ex}}=530 \mathrm{~nm}\right)$ and (b) compound $2\left(\lambda_{\mathrm{em}}=526 \mathrm{~nm} ; \lambda_{\mathrm{ex}}=480 \mathrm{~nm}\right)$ were measured every five minutes.

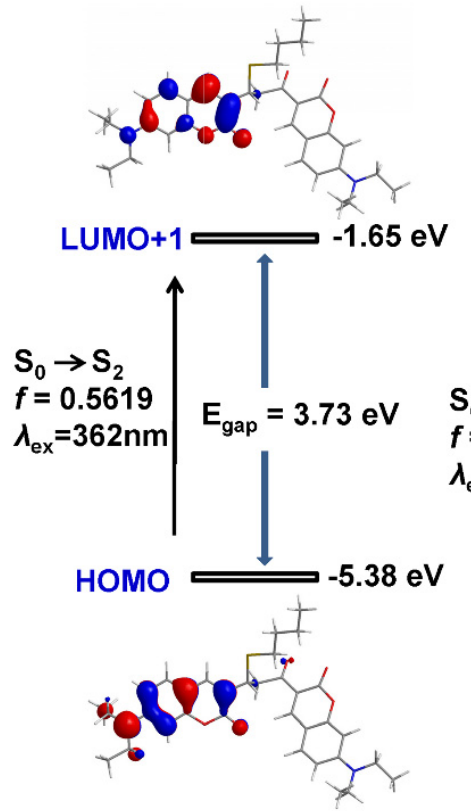

(a)

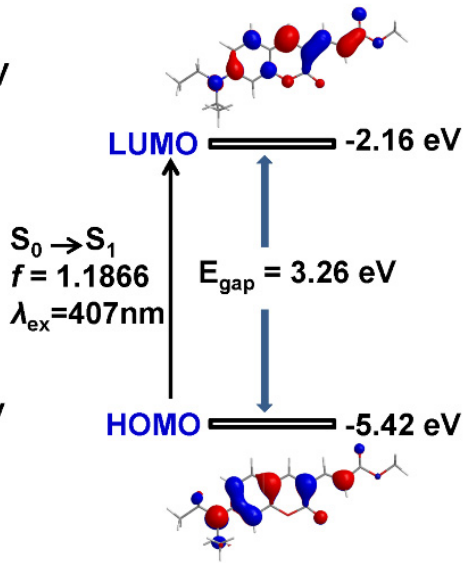

(b)

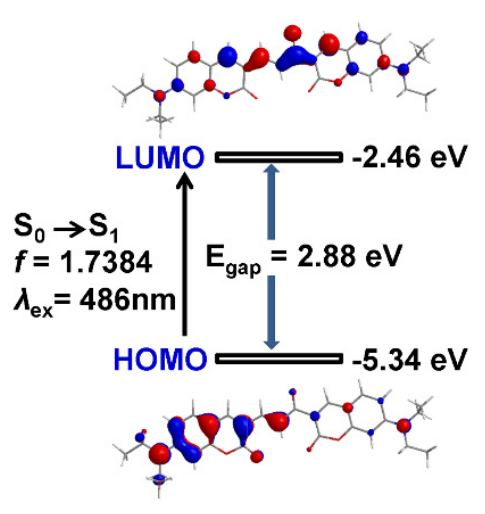

(c)

Figure S8. The HOMO and LUMO energy levels and the orbitals of (a) compound Hy-1, (b) compound 2, and (c) compound 1. 

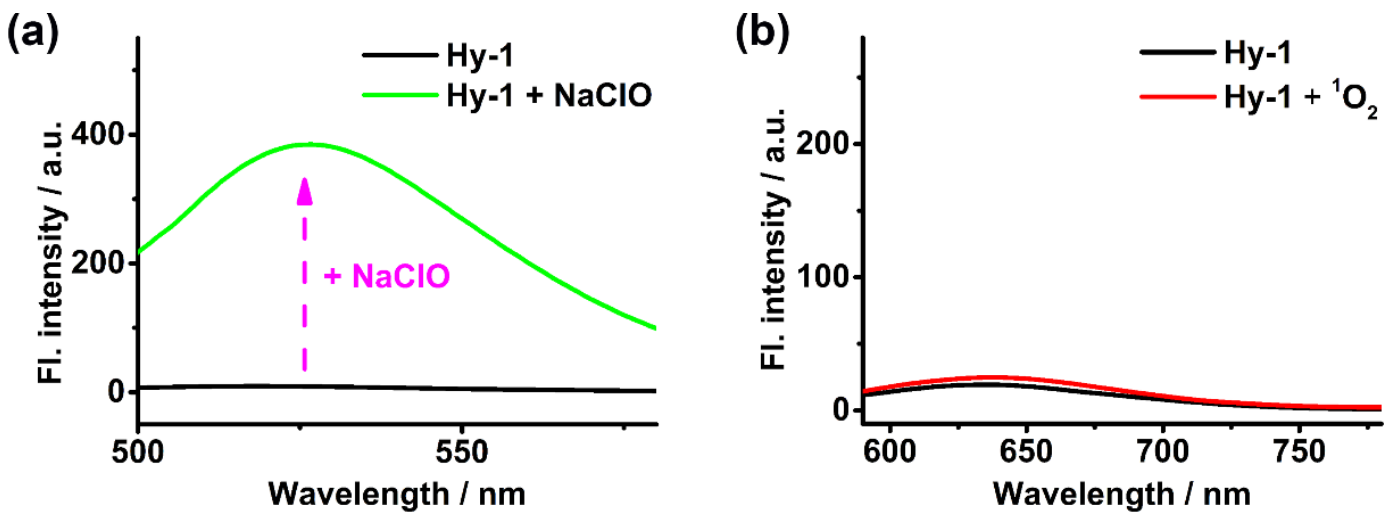

Figure S9. (a) The fluorescence spectra in green channel of Hy-1 (5 $\mu \mathrm{M})$ upon incubating with $500 \mu \mathrm{M} \mathrm{NaClO}$ in aqueous buffer / methanol (4: $1 \mathrm{v} / \mathrm{v})$. (b) The fluorescence spectra in red channel of Hy-1 $(5 \mu \mathrm{M})$ upon incubating with $1.8 \mathrm{mM}^{1} \mathrm{O}_{2}$ in aqueous buffer / methanol (4: $1 \mathrm{v} / \mathrm{v})$. The ${ }^{1} \mathrm{O}_{2}$ was generated from a $\mathrm{Na}_{2} \mathrm{MoO}_{4} / \mathrm{H}_{2} \mathrm{O}_{2}$ system.
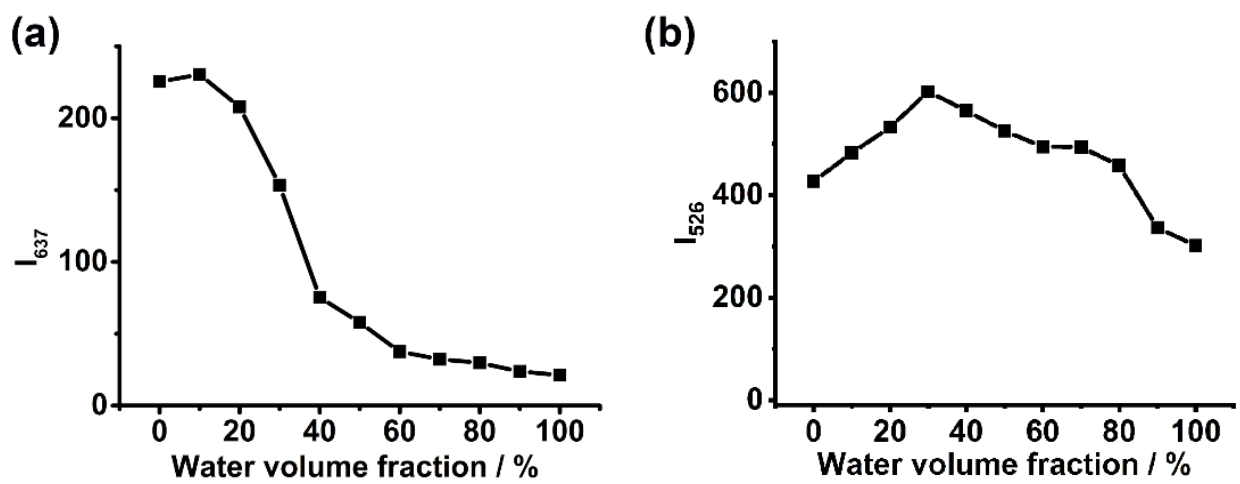

Figure S10. (a) The fluorescence intensity of compound 1 at $637 \mathrm{~nm}$ (a) and compound 2 at $526 \mathrm{~nm}(\mathrm{~b})$ in the solution with different water volume fraction. 


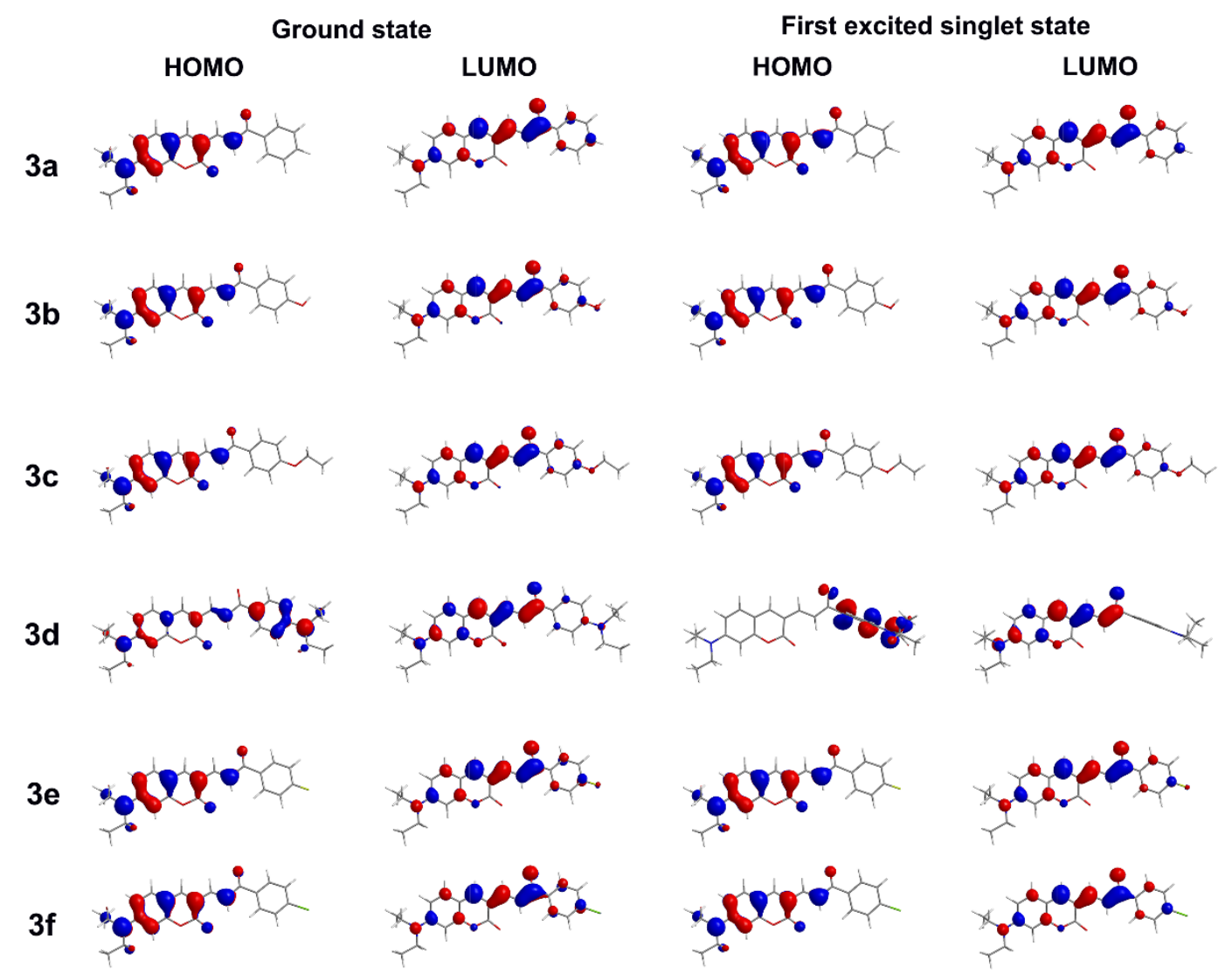

Figure S11. Frontier molecular orbitals of compounds 3a-3f.

(a)

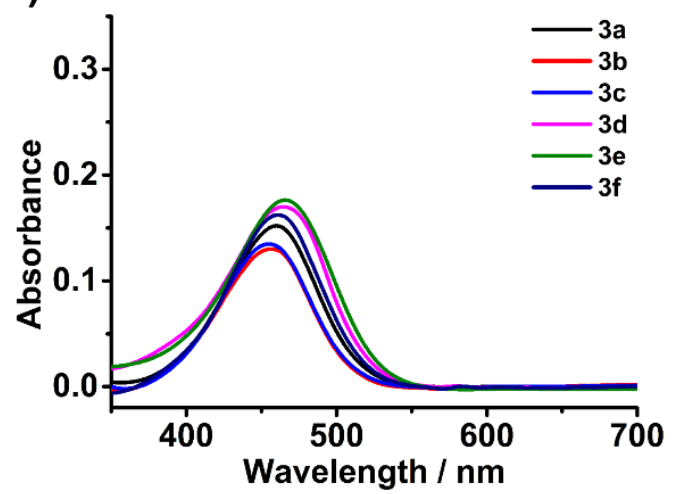

(b)

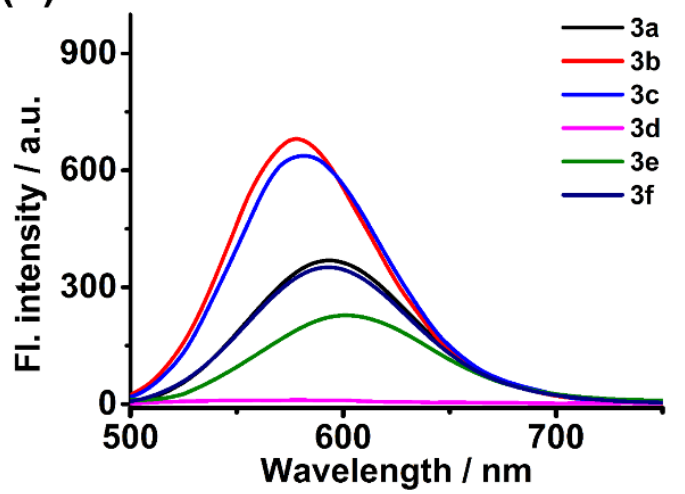

Figure S12. (a) The UV-Vis absorption spectra of compound 3a-3f in methanol; (b) The fluorescence emission spectra of compound 3a-3f in methanol. 
Table S2. Photophysical data for compounds 3a-3f in methanol.

\begin{tabular}{ccccc}
\hline Compound & $\begin{array}{c}\text { Absorption } \\
\lambda_{\max }[\mathrm{nm}]\end{array}$ & $\varepsilon\left[\mathrm{M}^{-1} \mathrm{~cm}^{-1}\right]$ & $\begin{array}{c}\text { Emission } \\
\lambda_{\max }[\mathrm{nm}]\end{array}$ & $\Phi_{\mathrm{f}}{ }^{\mathrm{a}]}$ \\
\hline 3a & 460 & 30410 & 593 & 0.376 \\
3b & 456 & 25988 & 578 & 0.616 \\
3c & 455 & 26956 & 582 & 0.564 \\
3d & 464 & 33988 & $/$ & 0.020 \\
3e & 466 & 35264 & 601 & 0.234 \\
3f & 461 & 32424 & 593 & 0.363 \\
\hline
\end{tabular}

[a] Fluorescence quantum yields calculated using Rhodamine $6 \mathrm{G}$ as the standard.

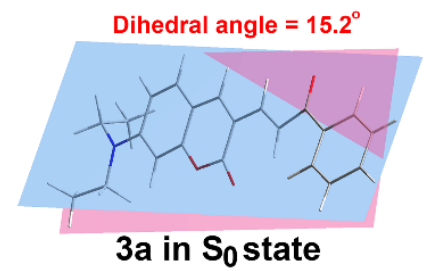

Dihedral angle $=\mathbf{5 . 2}$

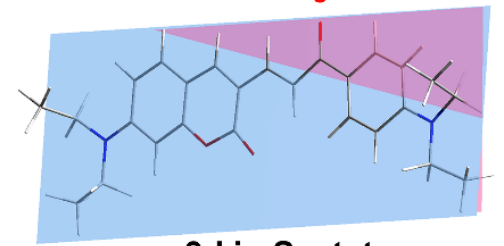

$3 d$ in $S_{0}$ state

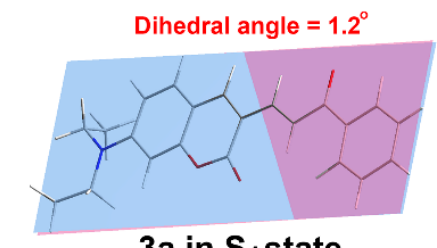

$3 a$ in $S_{1}$ state

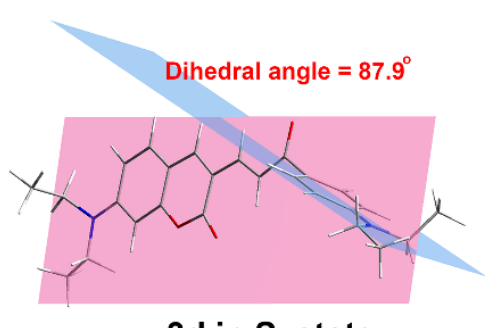

$3 d$ in $S_{1}$ state

Figure S13. Dihedral angles between the coumarin and the phenyl rings of compounds $\mathbf{3 a}$ and $\mathbf{3 d}$. 
Table S3 Dihedral angles between the coumarin and phenyl rings as calculated using the optimized $\mathrm{S}_{0}$ and $\mathrm{S}_{1}$ geometries.

\begin{tabular}{ccc}
\hline \multirow{2}{*}{ Compound } & \multicolumn{2}{c}{$\varphi$} \\
\cline { 2 - 3 } & $\mathrm{S}_{0}$ & $\mathrm{~S}_{1}$ \\
\hline 3a & 15.2 & 1.2 \\
$\mathbf{3 b}$ & 9.9 & 1.1 \\
$\mathbf{3 c}$ & 8.2 & 1.3 \\
$\mathbf{3 d}$ & 5.2 & 87.9 \\
$\mathbf{3 e}$ & 14.3 & 1.6 \\
$\mathbf{3 f}$ & 15.2 & 0.6 \\
\hline
\end{tabular}


Table S4. Crystallographic parameters for compound $\mathbf{3 f}$.

\begin{tabular}{ll}
\hline Compound & 3f \\
\hline CCDC & 1952179 \\
Chemical formula & $\mathrm{C}_{22} \mathrm{H}_{20} \mathrm{ClNO}_{3}$ \\
formula weight & 381.84 \\
Wavelength $(\AA)$ & 0.71073 \\
Crystal system & Triclinic \\
Space group & $\mathrm{P}-1$ \\
$T(\mathrm{~K})$ & $293(2)$ \\
$a(\AA)$ & $6.9385(14)$ \\
$b(\AA)$ & $11.066(2)$ \\
$c(\AA)$ & $12.298(3)$ \\
$\alpha\left({ }^{\circ}\right)$ & $80.74(3)$ \\
$\beta\left({ }^{\circ}\right)$ & $84.13(3)$ \\
$\gamma\left({ }^{\circ}\right)$ & $80.41(3)$ \\
$V\left(\AA^{3}\right)$ & $916.2(3)$ \\
$Z$ & 2 \\
$D\left(\mathrm{mg} / \mathrm{m}^{-3}\right)$ & 1.384 \\
$F(000)$ & 400 \\
$\mu(\mathrm{Mo} \mathrm{Ka})\left(\mathrm{mm}{ }^{-1}\right)$ & 0.232 \\
$\theta$ range $\left({ }^{\circ}\right)$ & $3.28 \sim 26.02$ \\
Goodness of fit on $\mathrm{F}^{2}$ & 1.062 \\
$R 1, w R 2[I>2 \sigma(I)]$ & $0.0337,0.0922$ \\
Reflections collected / unique & $8463 / 3468[\mathrm{R}(\mathrm{int})=0.0215]$ \\
$R$ indices $($ all data $)$ & $0.0400,0.0952$ \\
\hline & \\
&
\end{tabular}

$R=\Sigma|| F_{0}|-| F_{\mathrm{c}}|| \Sigma\left|F_{0}\right|, w R_{2}=\left\{\Sigma\left[\mathrm{w}\left(F_{0}^{2}-F_{\mathrm{c}}^{2}\right)^{2}\right] / \Sigma\left[w\left(F_{0}^{2}\right)^{2}\right]\right\}^{1 / 2}$ 

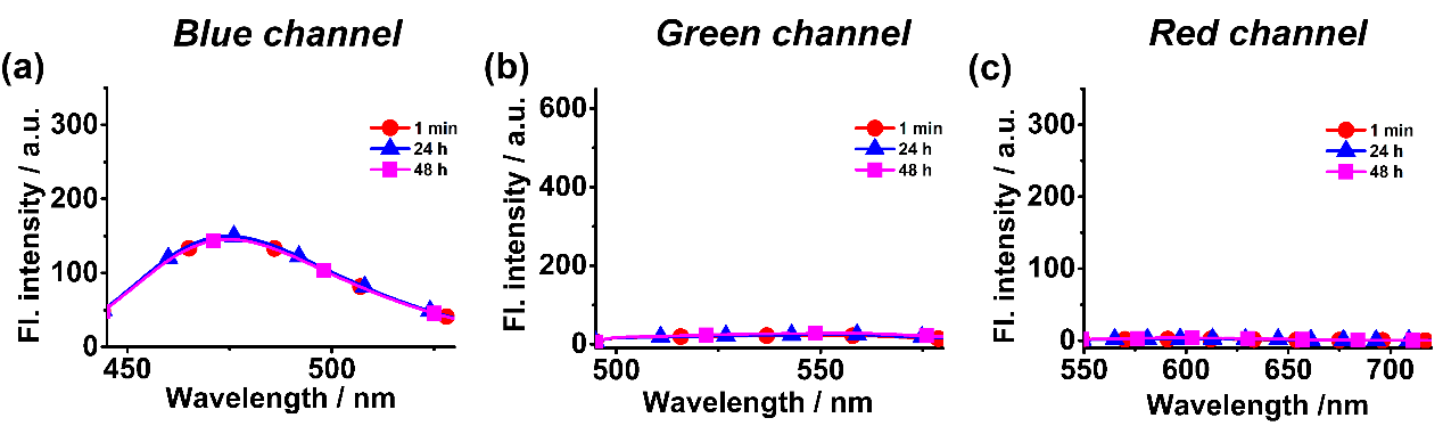

Figure S14. The fluorescence spectra of probe Hy-2 $(5 \mu \mathrm{M})$ in $50 \mathrm{mM}$ potassium phosphate buffer / methanol (4: $1 \mathrm{v} / \mathrm{v})$ solution for $1 \min (\bullet), 24$ hours $(\boldsymbol{\Delta})$ and 48 hours ( $\square$ ). (a) blue channel $\left(\lambda_{\mathrm{ex}}=420 \mathrm{~nm}\right)$, (b) green channel $\left(\lambda_{\mathrm{ex}}=480 \mathrm{~nm}\right)$, and (c) red channel $\left(\lambda_{\mathrm{ex}}=530 \mathrm{~nm}\right)$.

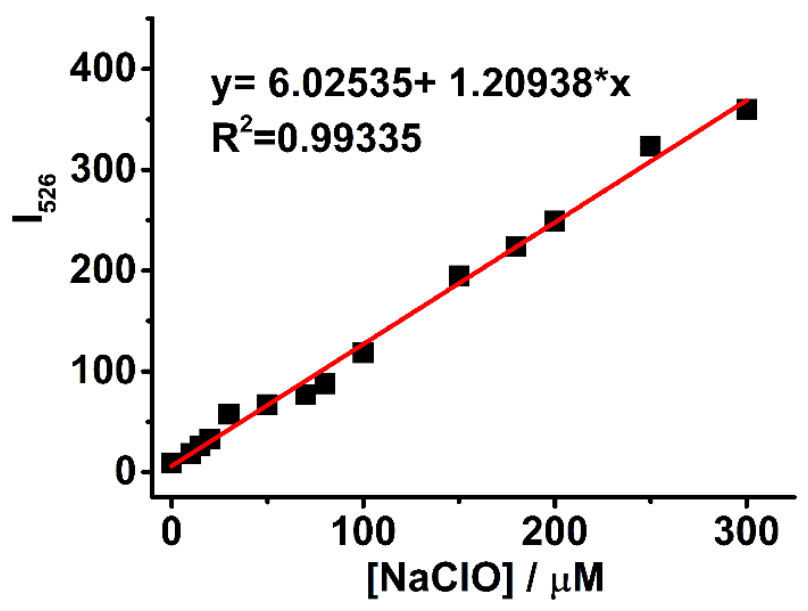

Figure S15. The fluorescence intensity of Hy-2 $(5 \mu \mathrm{M})$ in the green channel (I526) to various amount of $\mathrm{ClO}^{-}(0$ to $300 \mu \mathrm{M})$. 


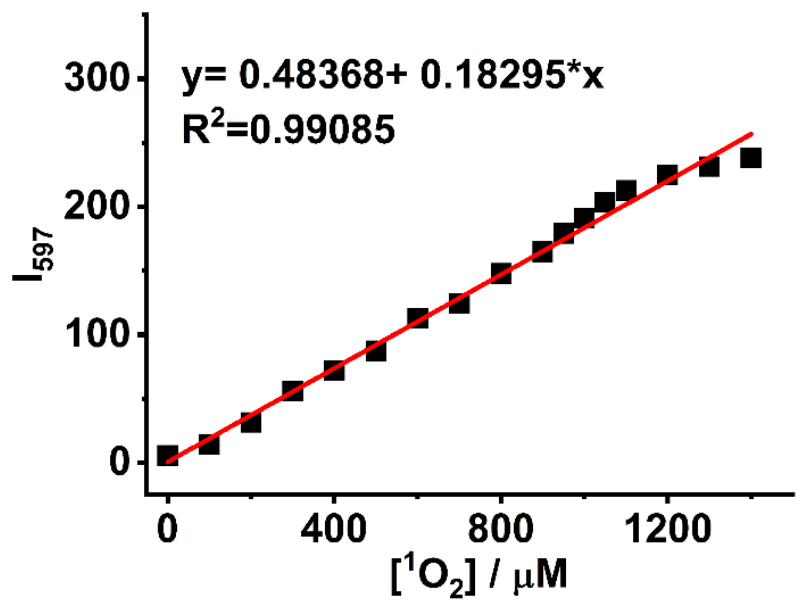

Figure S16. The fluorescence intensity of $\mathbf{H y}-2(5 \mu \mathrm{M})$ in the red channel ( $\left.\mathrm{I}_{597}\right)$ to various amount of ${ }^{1} \mathrm{O}_{2}(0$ to $1.4 \mathrm{mM})$. The ${ }^{1} \mathrm{O}_{2}$ was generated from a $\mathrm{Na}_{2} \mathrm{MoO}_{4} / \mathrm{H}_{2} \mathrm{O}_{2}$ system.

(a)

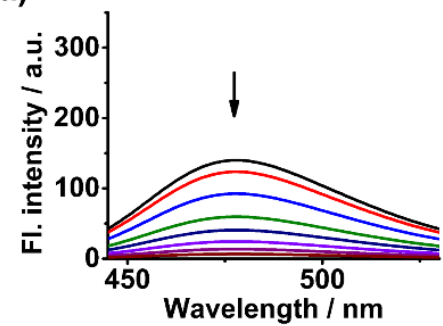

(b)

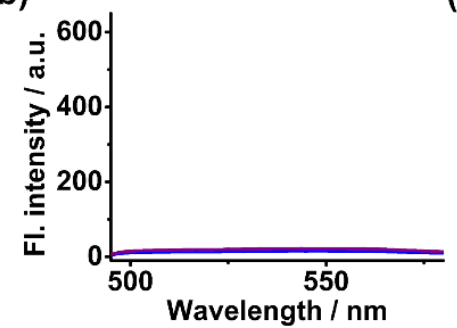

(c)

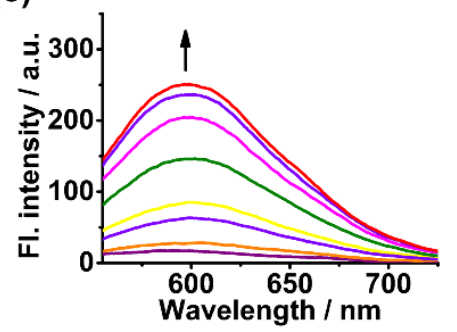

Figure S17. Fluorescence changes in blue channel $\left(\lambda_{\mathrm{ex}}=420 \mathrm{~nm}\right)(\mathrm{a})$, green channel $\left(\lambda_{\mathrm{ex}}=480 \mathrm{~nm}\right)(\mathrm{b})$, and red channel $\left(\lambda_{\mathrm{ex}}=530 \mathrm{~nm}\right)(\mathrm{c})$ of probe $\mathbf{H y}-\mathbf{2}(5 \mu \mathrm{M})$ in aqueous buffer / methanol (4: $1 \mathrm{v} / \mathrm{v})$ upon photoirradiation of co-dissolved TMPyP4 $(5 \mu \mathrm{M})$ from 0 second to 350 second. 
(a)

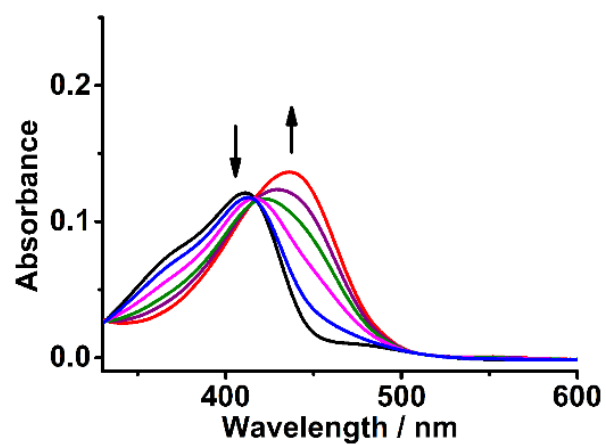

(b)

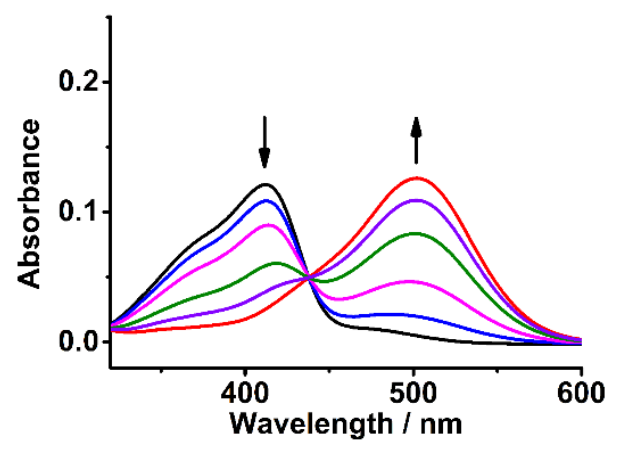

Figure S18. (a) Changes in absorption spectra of probe Hy-2 $(5 \mu \mathrm{M})$ with various amount of $\mathrm{ClO}^{-}(0-550 \mu \mathrm{M})$ in aqueous buffer / methanol (4: $\left.1 \mathrm{v} / \mathrm{v}\right)$; (b) Changes in absorption spectra of probe $\mathbf{H y}-\mathbf{2}(5 \mu \mathrm{M})$ with various amount of ${ }^{1} \mathrm{O}_{2}(0-2.0 \mathrm{mM})$ in aqueous buffer / methanol (4: $1 \mathrm{v} / \mathrm{v})$. The ${ }^{1} \mathrm{O}_{2}$ was generated from a $\mathrm{Na}_{2} \mathrm{MoO}_{4} / \mathrm{H}_{2} \mathrm{O}_{2}$ system.

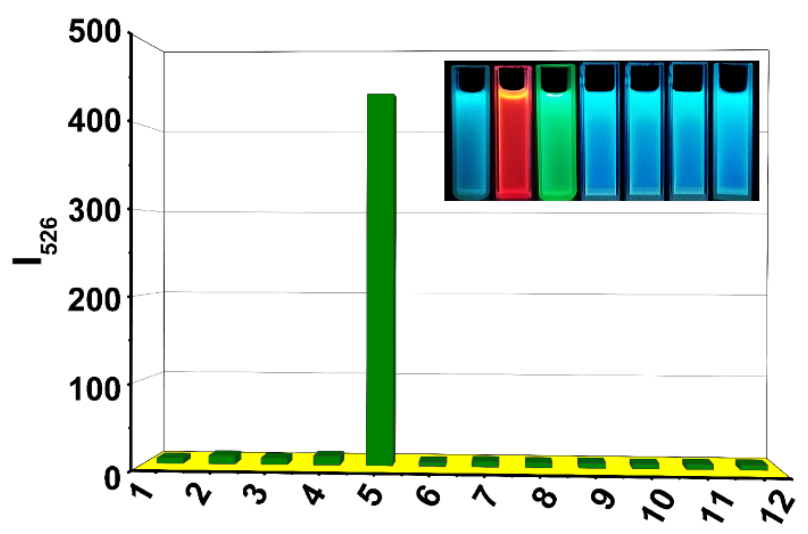

Figure S19. Fluorescence intensity of probe $\mathbf{H y}-2(5 \mu \mathrm{M})$ at $526 \mathrm{~nm}\left(\lambda_{\mathrm{ex}}=480 \mathrm{~nm}\right)$ after the addition of various species $(550 \mu \mathrm{M})$. (1) blank; (2) NO; (3) $\mathrm{OH}$; (4) $\mathrm{H}_{2} \mathrm{O}_{2}$; (5) $\mathrm{ClO}^{-}$; (6) ${ }^{1} \mathrm{O}_{2}$; (7) GSH; (8) Cys; (9) $\mathrm{Mg}^{2+}$; (10) $\mathrm{Fe}^{2+}$; (11) $\mathrm{Fe}^{3+}$; (12) $\mathrm{Zn}^{2+}$. Inset: visual fluorescence color changes of probe $\mathbf{H y}-\mathbf{2}(5 \mu \mathrm{M})$ in the presence of various species $(550 \mu \mathrm{M})$, the photo was taken under illumination of a handheld UV lamp, from left to right: blank, ${ }^{1} \mathrm{O}_{2}, \mathrm{ClO}^{-}, \mathrm{NO}, \mathrm{OH}, \mathrm{H}_{2} \mathrm{O}_{2}, \mathrm{GSH}$. The ${ }^{1} \mathrm{O}_{2}$ was generated from a $\mathrm{Na}_{2} \mathrm{MoO}_{4} / \mathrm{H}_{2} \mathrm{O}_{2}$ system. 




Figure S20. Fluorescence intensity of probe $\mathbf{H y - 2}(5 \mu \mathrm{M})$ at $597 \mathrm{~nm}\left(\lambda_{\mathrm{ex}}=530 \mathrm{~nm}\right)$ after the addition of various species (2 mM). (1) blank; (2) NO; (3) $\mathrm{OH}$; (4) $\mathrm{H}_{2} \mathrm{O}_{2}$; (5) $\mathrm{ClO}^{-}$; (6) ${ }^{1} \mathrm{O}_{2}$; (7) GSH; (8) Cys; (9) $\mathrm{Mg}^{2+}$; (10) $\mathrm{Fe}^{2+}$; (11) $\mathrm{Fe}^{3+}$; (12) $\mathrm{Zn}^{2+}$. The ${ }^{1} \mathrm{O}_{2}$ was generated from a $\mathrm{Na}_{2} \mathrm{MoO}_{4} / \mathrm{H}_{2} \mathrm{O}_{2}$ system.

(a)

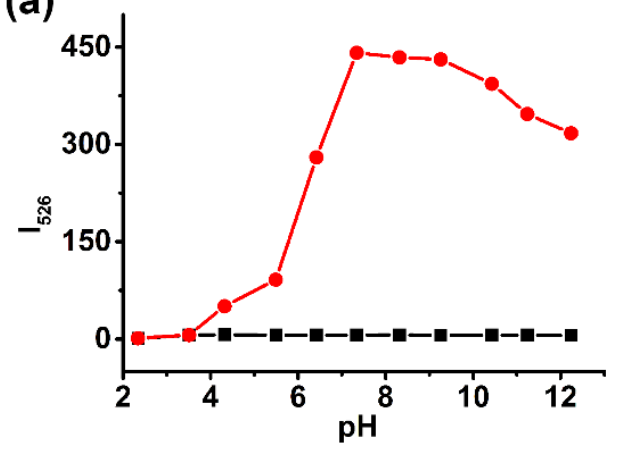

(b)

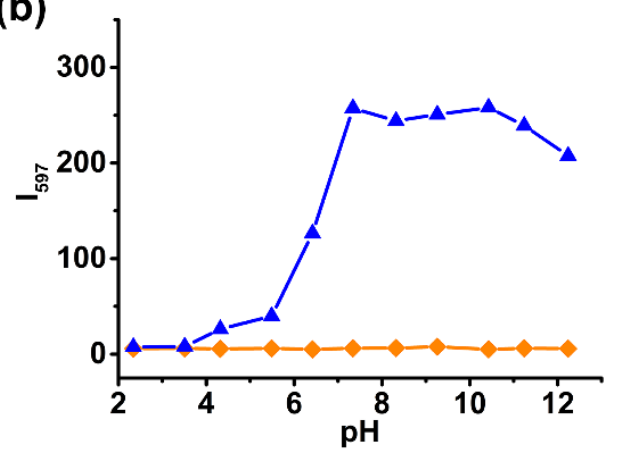

Figure S21. (a) The fluorescence intensity response $\left(\lambda_{\mathrm{em}}=526 \mathrm{~nm}, \lambda_{\mathrm{ex}}=480 \mathrm{~nm}\right)$ of probe Hy-2 $(5 \mu \mathrm{M})$ in $50 \mathrm{mM}$ potassium phosphate buffer / methanol $(4: 1 \mathrm{v} / \mathrm{v})$ at different $\mathrm{pH}$ condition before $(\boldsymbol{\bullet})$ and after $(\bullet)$ treatment with $\mathrm{ClO}^{-}(550 \mu \mathrm{M})$. (b) The fluorescence intensity response $\left(\lambda_{\mathrm{em}}=597 \mathrm{~nm}, \lambda_{\mathrm{ex}}=530 \mathrm{~nm}\right)$ of probe $\mathbf{H y - 2}(5 \mu \mathrm{M})$ in $50 \mathrm{mM}$ potassium phosphate buffer / methanol (4: $1 \mathrm{v} / \mathrm{v})$ at different $\mathrm{pH}$ condition before $(\diamond)$ and after $(\Delta)$ treatment with ${ }^{1} \mathrm{O}_{2}$. The ${ }^{1} \mathrm{O}_{2}$ was generated from photoirradiation of co-dissolved TMPyP4 $(5 \mu \mathrm{M})$ for 350 seconds. 
(a)

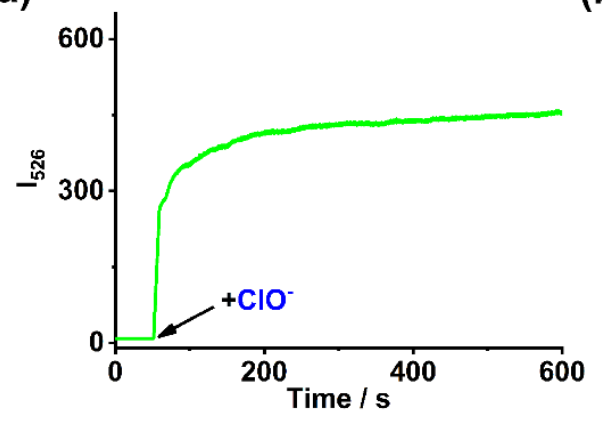

(b)

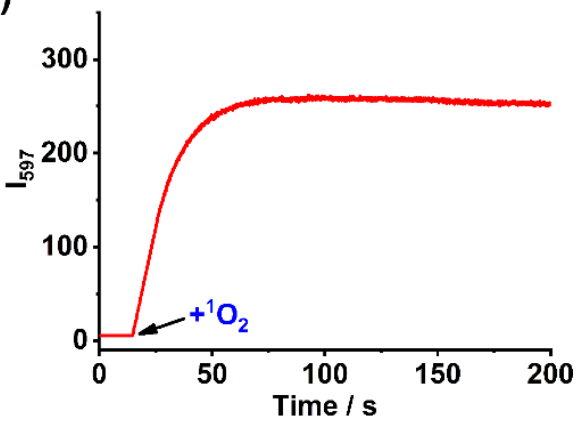

Figure S22. Time dependent fluorescence intensity changes of probe $\mathbf{H y}-\mathbf{2}(5 \mu \mathrm{M})$ in the absence and presence of (a) $550 \mu \mathrm{M} \mathrm{ClO}^{-}\left(\lambda_{\mathrm{em}}=526 \mathrm{~nm} ; \lambda_{\mathrm{ex}}=480 \mathrm{~nm}\right)$ and (b) 2.0 $\mathrm{mM}{ }^{1} \mathrm{O}_{2}\left(\lambda_{\text {em }}=597 \mathrm{~nm} ; \lambda_{\text {ex }}=530 \mathrm{~nm}\right)$. The ${ }^{1} \mathrm{O}_{2}$ was generated from a $\mathrm{Na}_{2} \mathrm{MoO}_{4} / \mathrm{H}_{2} \mathrm{O}_{2}$ system.

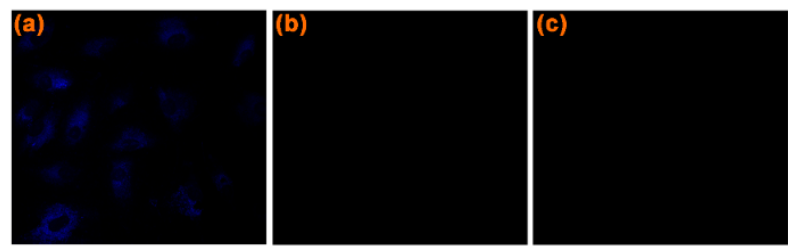

Figure S23. Confocal image of HepG2 cells incubated with Hy-2 $(1 \mu \mathrm{M})$. (a): blue ( $\lambda_{\text {em }}$ $=450-490 \mathrm{~nm}),(\mathrm{b})$ : green channel $\left(\lambda_{\mathrm{em}}=500-550 \mathrm{~nm}\right)$, and $(\mathrm{c})$ : red channel $\left(\lambda_{\mathrm{em}}=575-\right.$ $650 \mathrm{~nm})$.

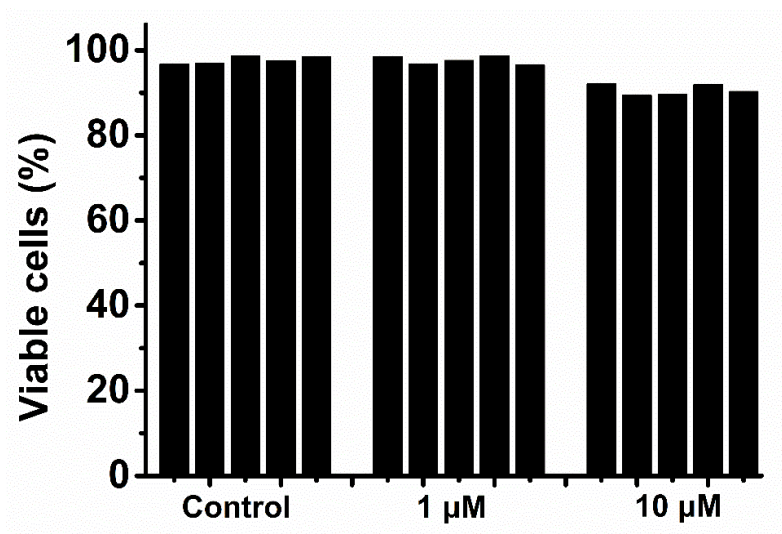

Figure S24. Cytotoxicity of $\mathbf{H y - 2}$ in cultured HepG2 cells. The cells were incubated with $\mathbf{H y}-2$ at 1 and $10 \mu \mathrm{M}$ for $24 \mathrm{~h}(\mathrm{n}=5)$. The cell viability was measured by MTT assay, and the data are reported as the percentage relative to the untreated cells. 


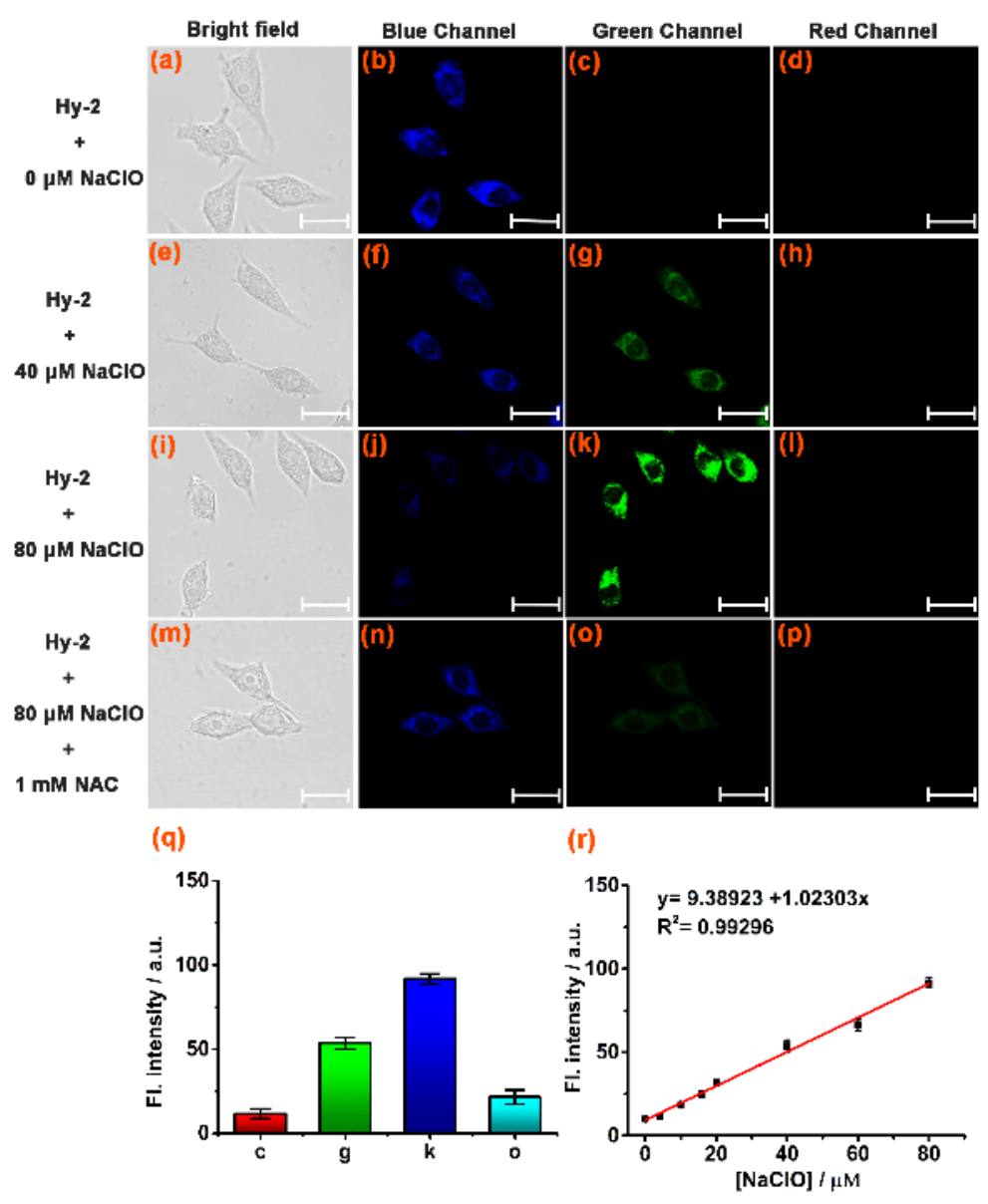

Figure S25. Confocal fluorescence imaging of exogenous $\mathrm{ClO}^{-}$in $\mathrm{HepG} 2$ cells by $\mathbf{H y -}$ $2(1 \mu \mathrm{M})$. (a-d): The images of $\mathbf{H y}-\mathbf{2}$ stained HepG2 cells with $0 \mu \mathrm{M} \mathrm{ClO}^{-}$in bright field, blue channel $\left(\lambda_{\mathrm{em}}=450-490 \mathrm{~nm}\right)$, green channel $\left(\lambda_{\mathrm{em}}=500-550 \mathrm{~nm}\right)$ and red channel $\left(\lambda_{\mathrm{em}}=575-650 \mathrm{~nm}\right)$. (e-h): The images of $\mathbf{H y - 2}$ stained HepG2 cells with $40 \mu \mathrm{M} \mathrm{ClO}^{-}$ in bright field, blue channel, green channel and red channel. (i-1): The images of $\mathbf{H y - 2}$ stained HepG2 cells with $80 \mu \mathrm{M} \mathrm{ClO}^{-}$in bright field, blue channel, green channel and red channel. (m-p): The images of Hy-2 and NAC (1 mM) treated HepG2 cells with 80 $\mu \mathrm{M} \mathrm{ClO}^{-}$in bright field, blue channel, green channel and red channel. (q): Average intensity from images (c), (g), (k), and (o). (r): Linear relationship between the average intensity and $\mathrm{ClO}^{-}$concentration. Error bars represent the standard deviation. The scale bar in (a)-(p) is $20 \mu \mathrm{m}$. 

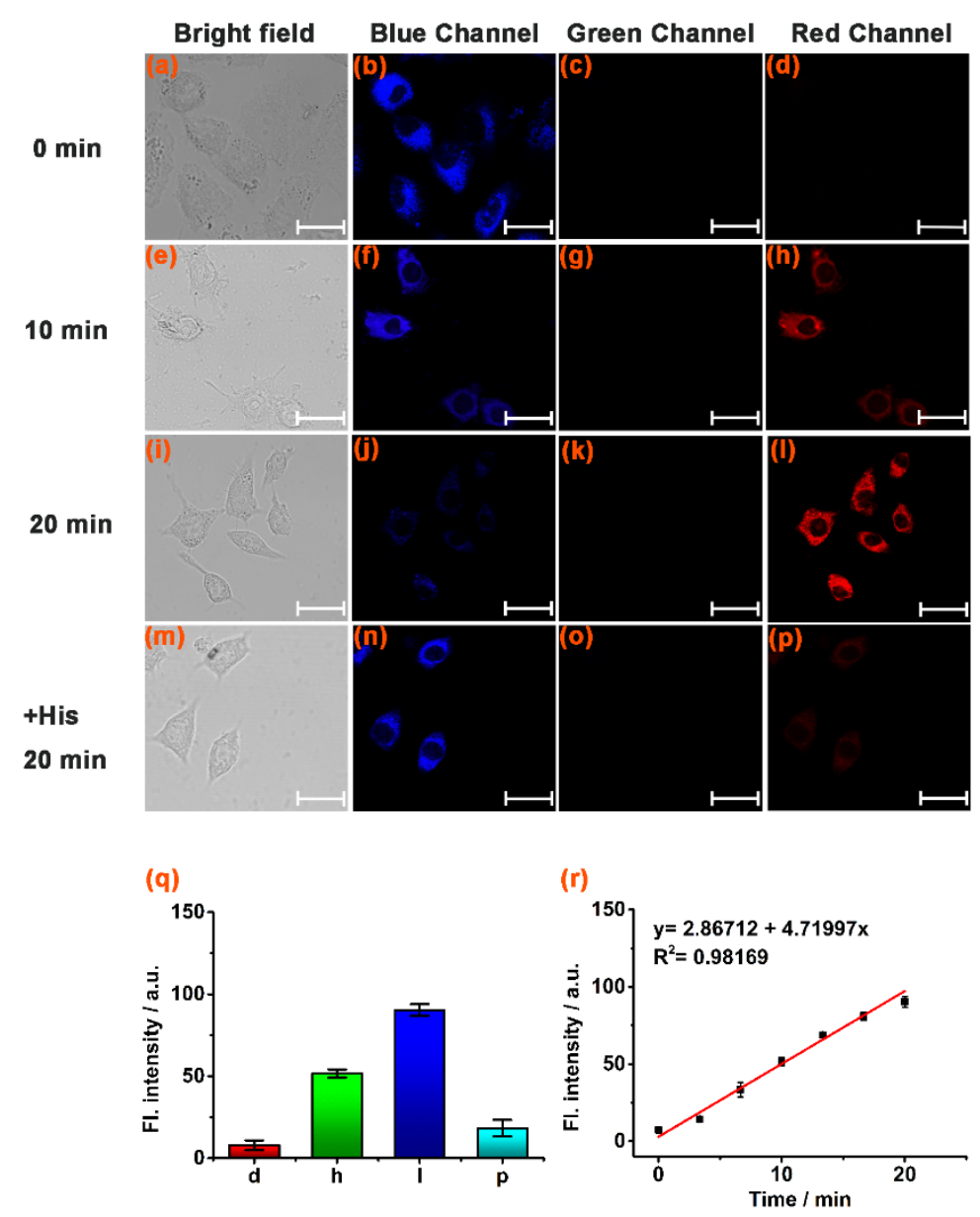

Figure S26. Confocal fluorescence imaging of photoirradiation-induced ${ }^{1} \mathrm{O}_{2}$ in HepG2 cells by Hy-2. (a-d): The images of 5-ALA $\left(150 \mu \mathrm{g} \mathrm{ml}^{-1}\right)$ and $\mathbf{H y - 2}(1 \mu \mathrm{M})$ treated HepG2 cells under photoirradiation for $0 \mathrm{~min}$ in bright field, blue channel $\left(\lambda_{\mathrm{em}}=450\right.$ $490 \mathrm{~nm})$, green channel $\left(\lambda_{\mathrm{em}}=500-550 \mathrm{~nm}\right)$ and red channel $\left(\lambda_{\mathrm{em}}=575-650 \mathrm{~nm}\right) .(\mathrm{e}-\mathrm{h})$ : The images of 5-ALA $\left(150 \mu \mathrm{g} \mathrm{ml}^{-1}\right)$ and $\mathbf{H y - 2}(1 \mu \mathrm{M})$ treated HepG2 cells under photoirradiation for $10 \mathrm{~min}$ in bright field, blue channel, green channel and red channel. (i-1): The images of 5-ALA $\left(150 \mu \mathrm{g} \mathrm{ml}^{-1}\right)$ and $\mathbf{H y - 2}(1 \mu \mathrm{M})$ treated HepG2 cells under photoirradiation for $20 \mathrm{~min}$ in bright field, blue channel, green channel and red channel. (m-p): The images of 5-ALA $\left(150 \mu \mathrm{g} \mathrm{ml}^{-1}\right)$, Hy-2 $(1 \mu \mathrm{M})$ and His $(2 \mathrm{mM})$ treated HepG2 cells under photoirradiation for $20 \mathrm{~min}$ in bright field, blue channel, green channel and red channel. (q): Average intensity from images (d), (h), (l), and (p). (r): Linear relationship between the average intensity and photoirradiation time. Error bars represent the standard deviation. The scale bar in (a)-(p) is $20 \mu \mathrm{m}$. 


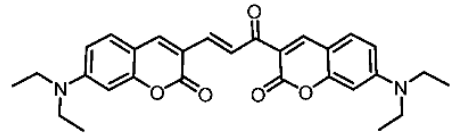
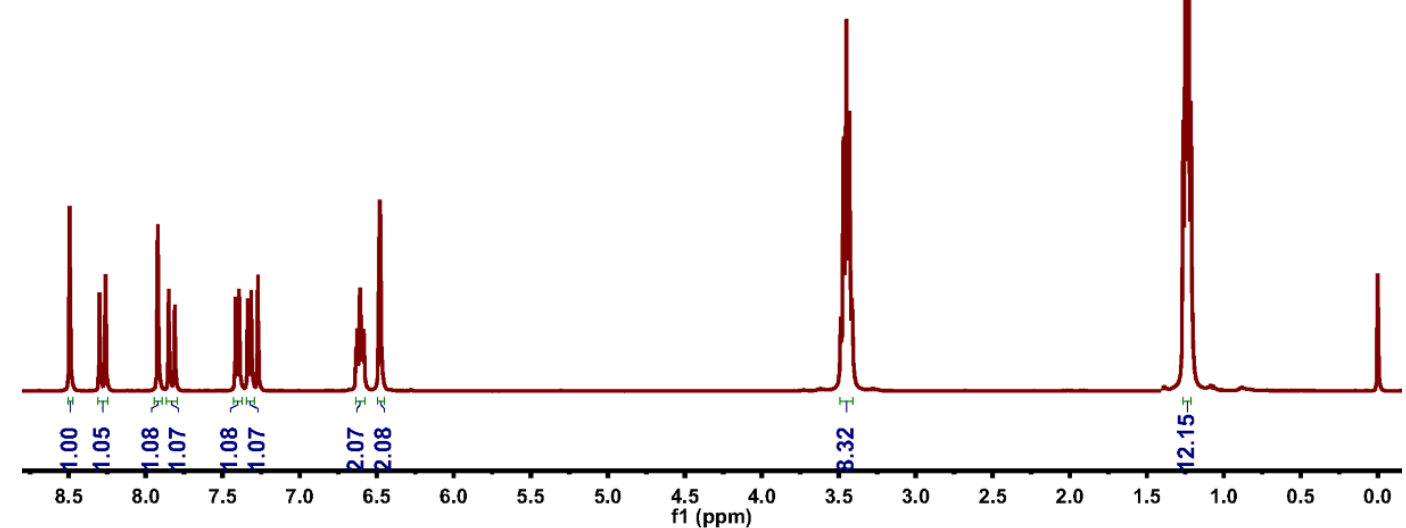

Figure S27. ${ }^{1} \mathrm{H}$ NMR spectra of compound 1 recorded in $\mathrm{CDCl}_{3}$.

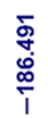
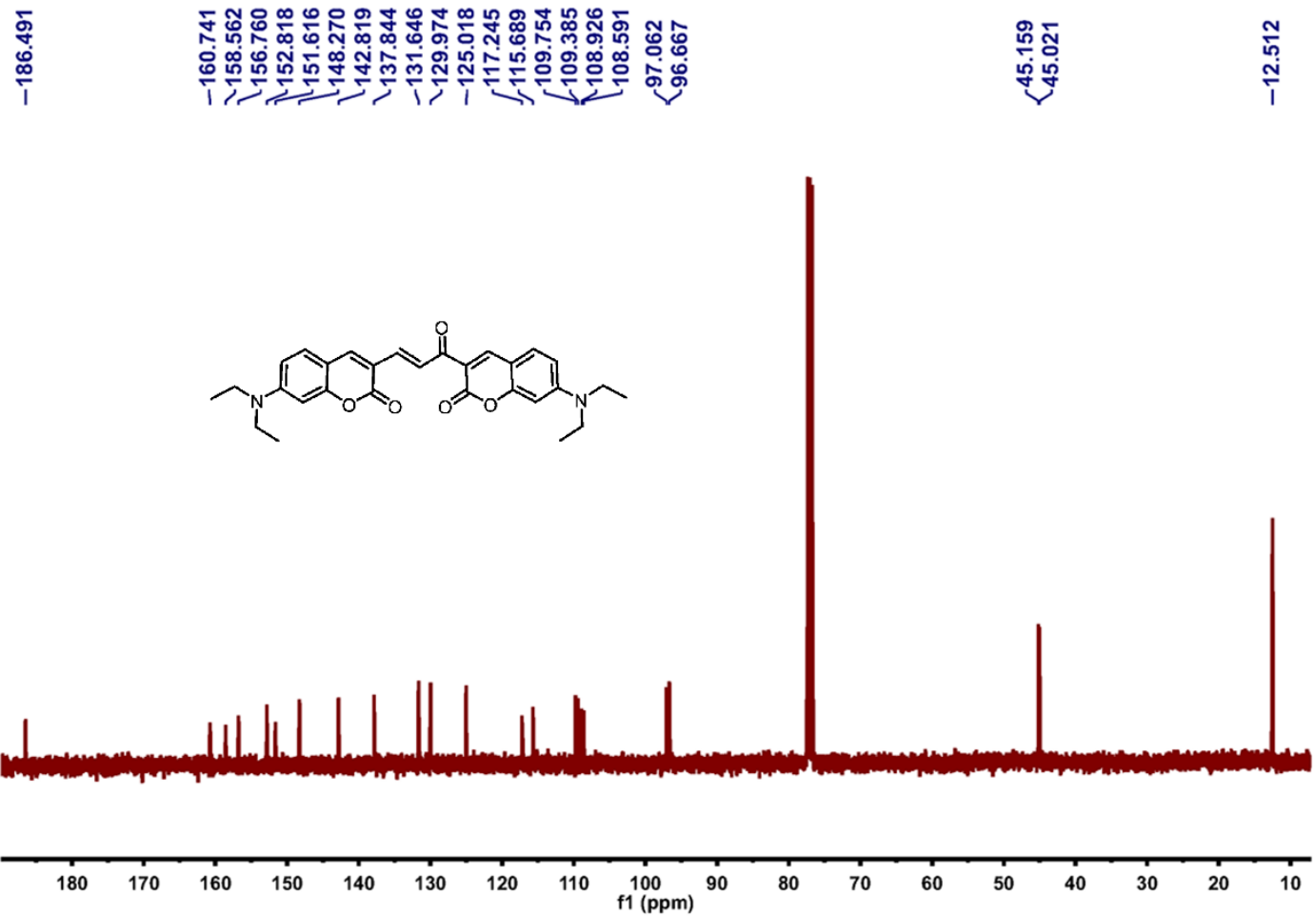

Figure S28. ${ }^{13} \mathrm{C}$ NMR spectra of compound 1 recorded in $\mathrm{CDCl}_{3}$. 


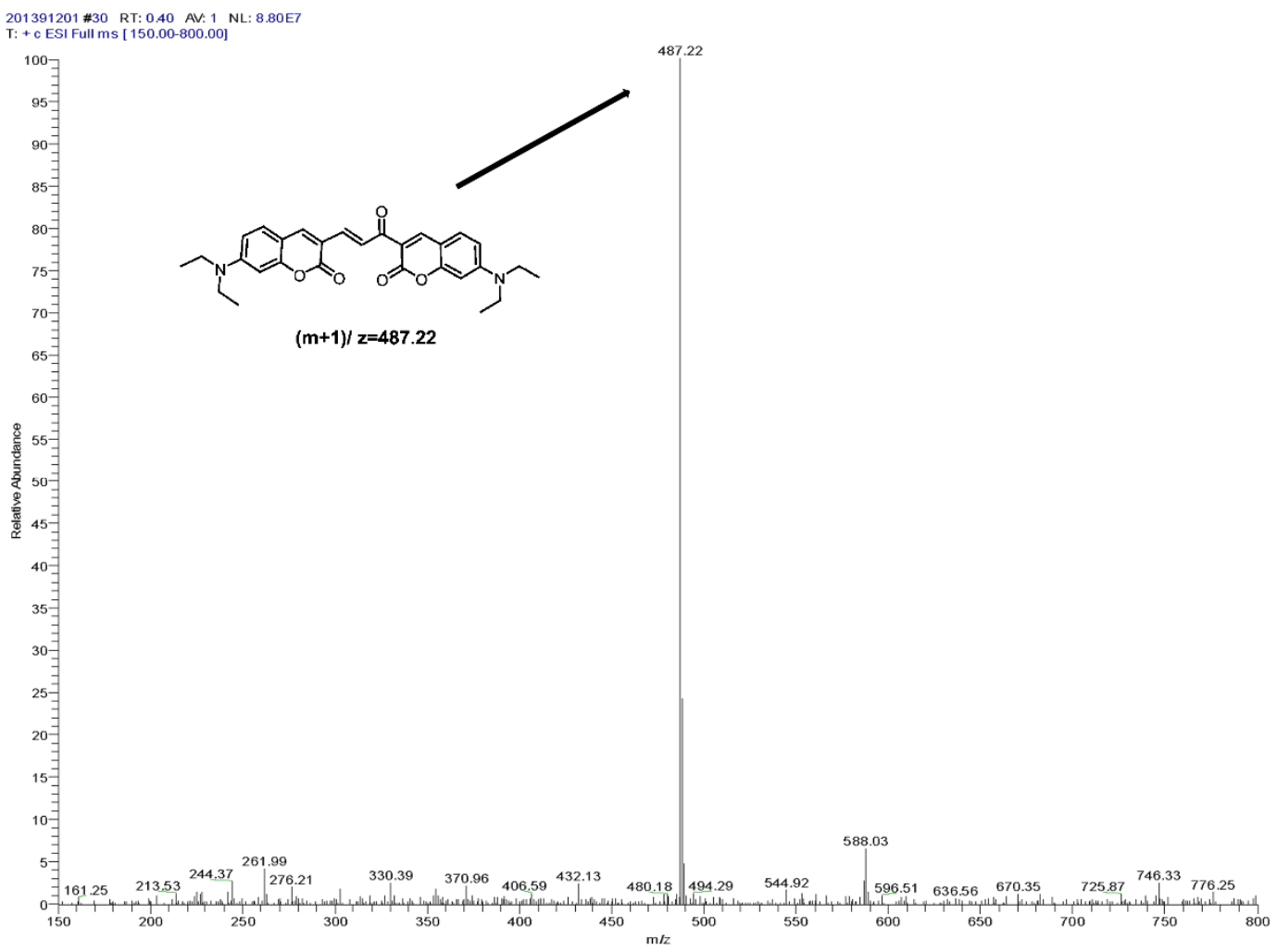

Figure S29. ESI-MS spectrum of compound 1.<smiles>CCN(CC)c1ccc2cc(/C=C/C(=O)c3ccccc3)c(=O)oc2c1</smiles>

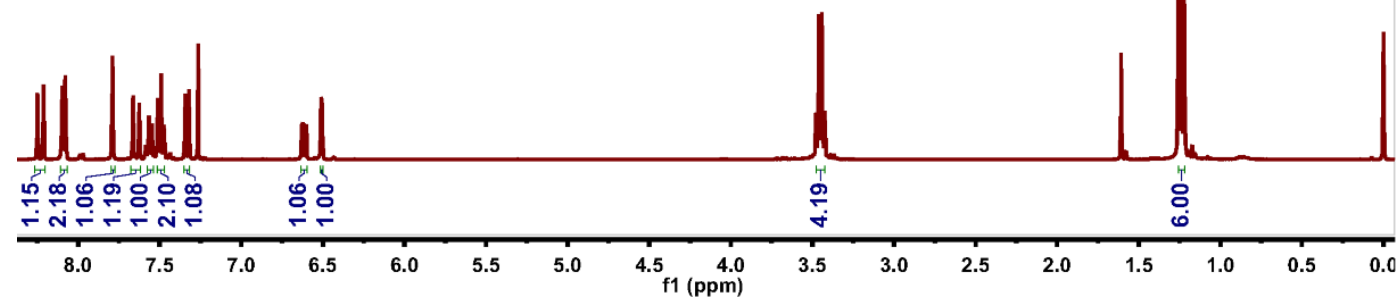

Figure S30. ${ }^{1} \mathrm{H}$ NMR spectra of compound 3a recorded in $\mathrm{CDCl}_{3}$. 

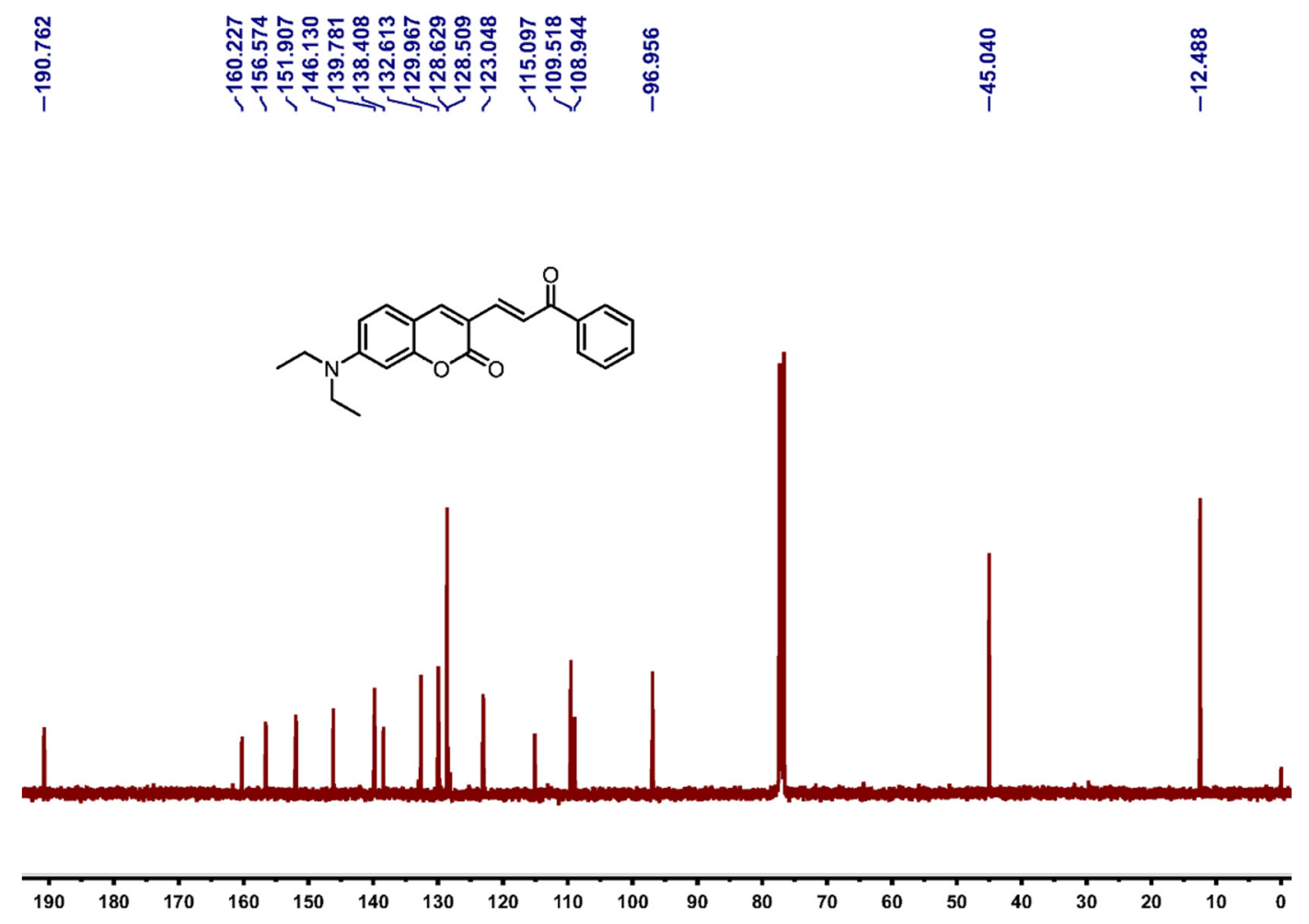

Figure S31. ${ }^{13} \mathrm{C}$ NMR spectra of compound 3a recorded in $\mathrm{CDCl}_{3}$.

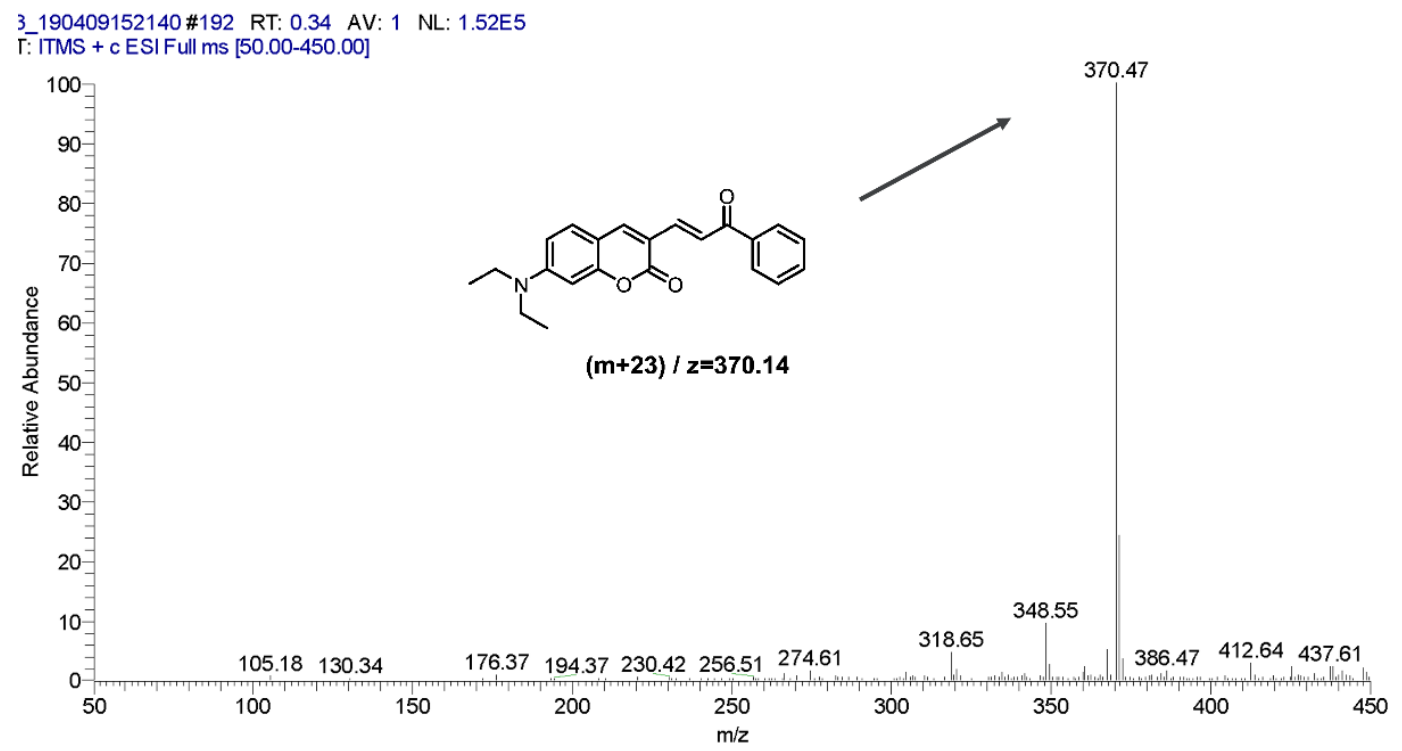

Figure S32. ESI-MS spectrum of compound $3 \mathbf{a}$. 
<smiles>CCN(CC)c1ccc2cc(/C=C/C(=O)c3ccc(O)cc3)c(=O)oc2c1</smiles>

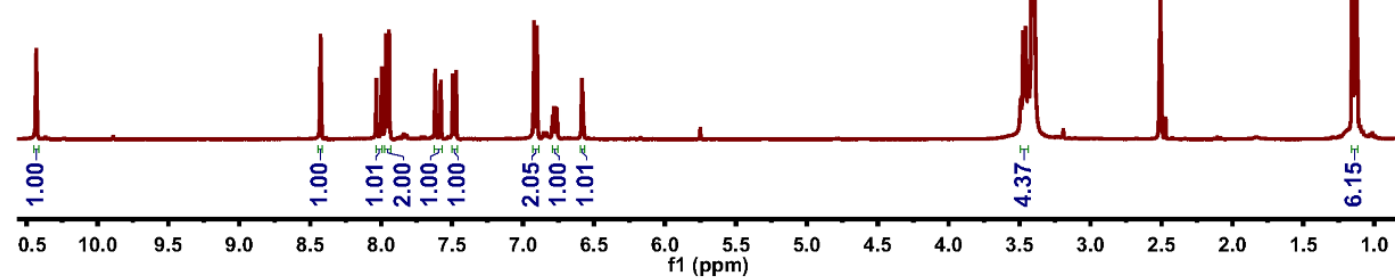

Figure S33. ${ }^{1} \mathrm{H}$ NMR spectra of compound $\mathbf{3 b}$ recorded in DMSO- $d 6$.
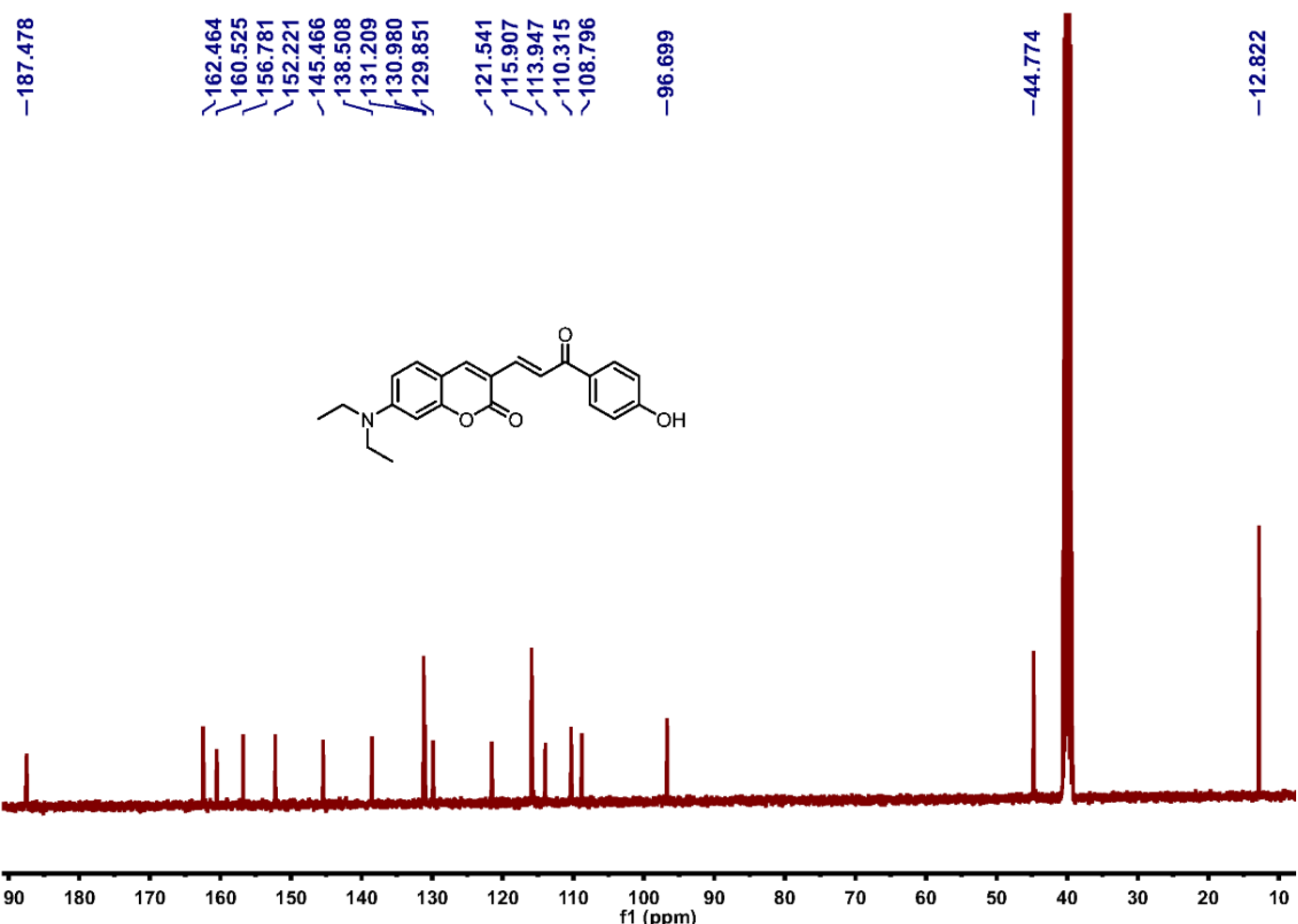

Figure S34. ${ }^{13} \mathrm{C}$ NMR spectra of compound $\mathbf{3 b}$ recorded in DMSO-d6. 


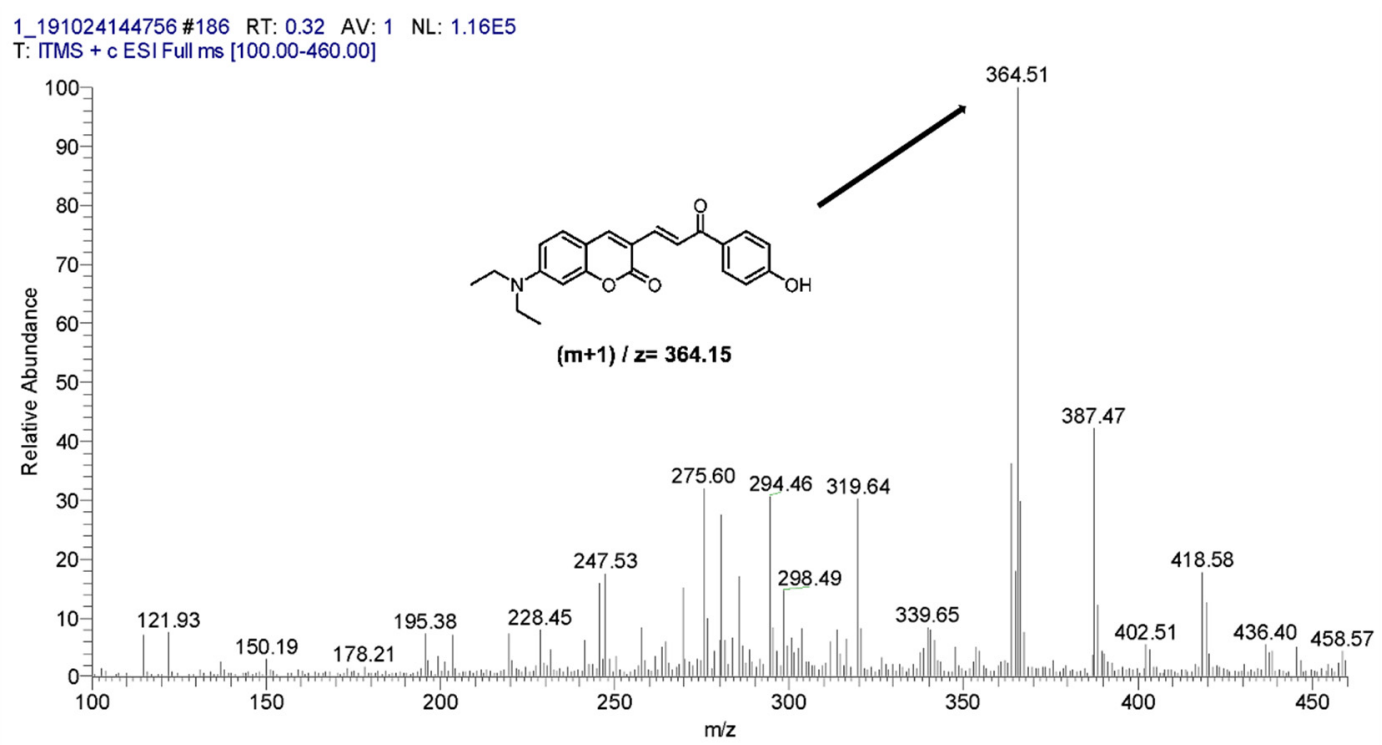

Figure S35. ESI-MS spectrum of compound $\mathbf{3 b}$.
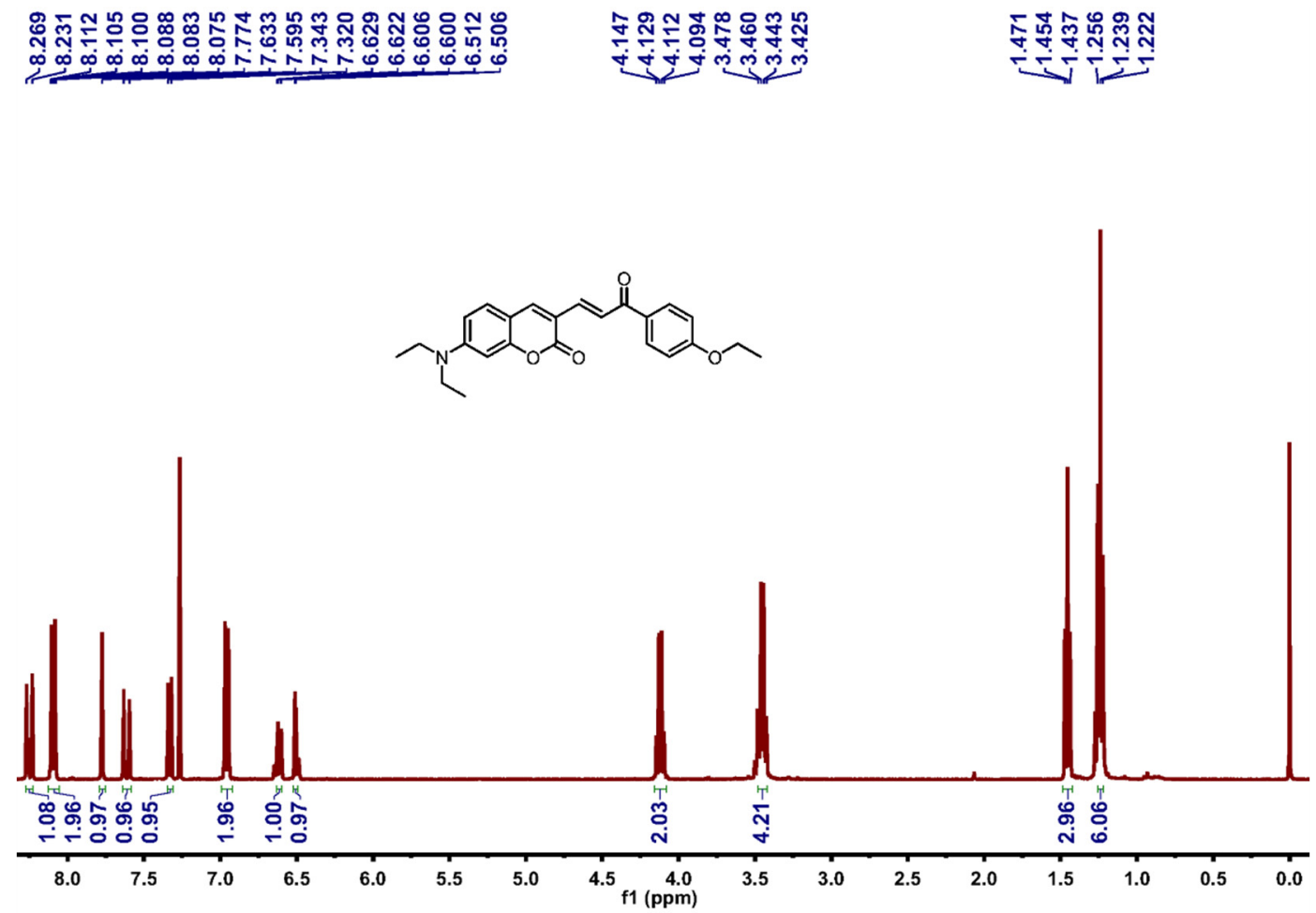

Figure S36. ${ }^{1} \mathrm{H}$ NMR spectra of compound $3 \mathbf{c}$ recorded in $\mathrm{CDCl}_{3}$. 

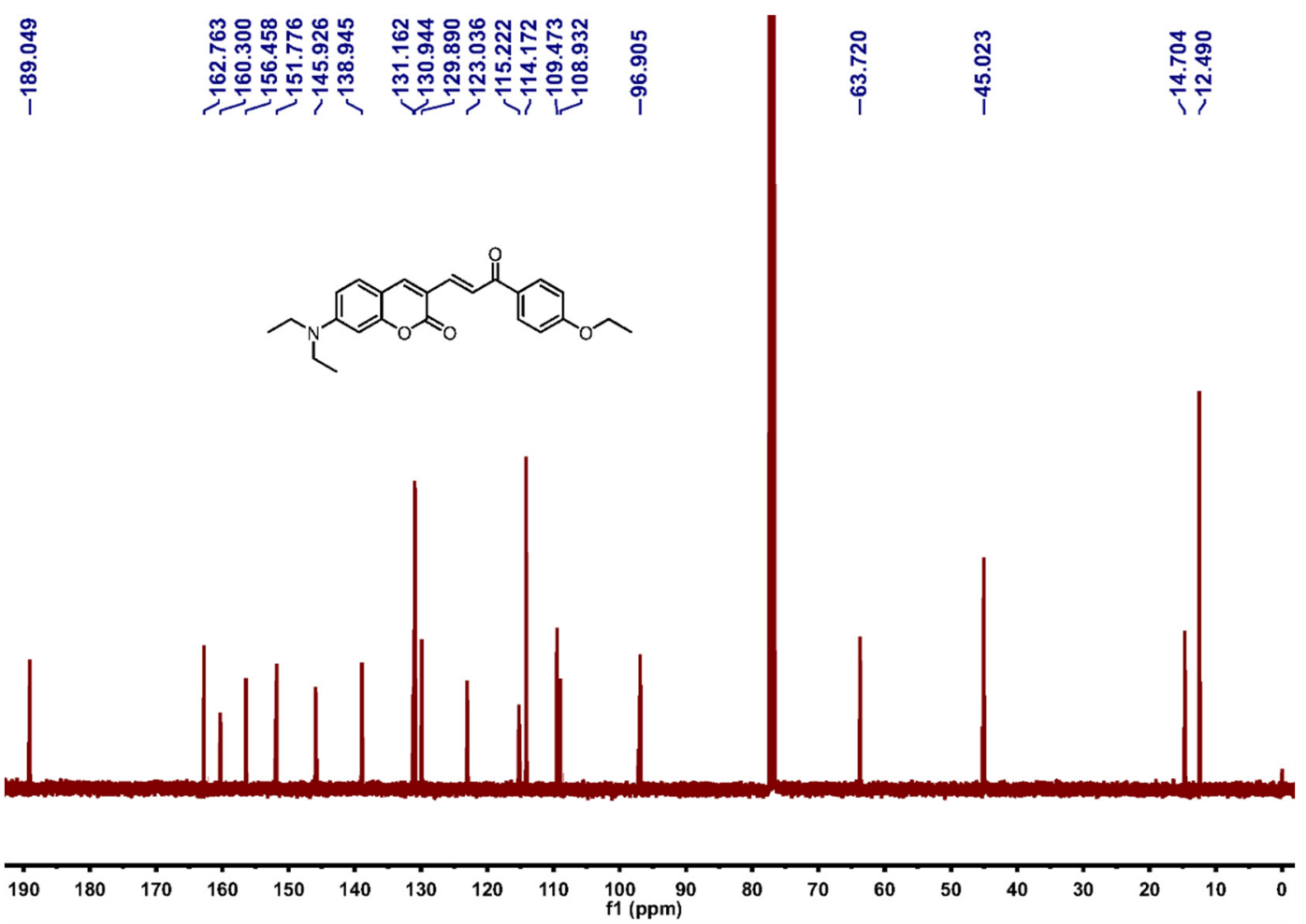

Figure S37. ${ }^{13} \mathrm{C}$ NMR spectra of compound $3 \mathrm{c}$ recorded in $\mathrm{CDCl}_{3}$.

2014011806 140117184449\#255 RT: 3.22 AV: 1 SB: $20.50,0.58$ NL: $3.66 E 7$

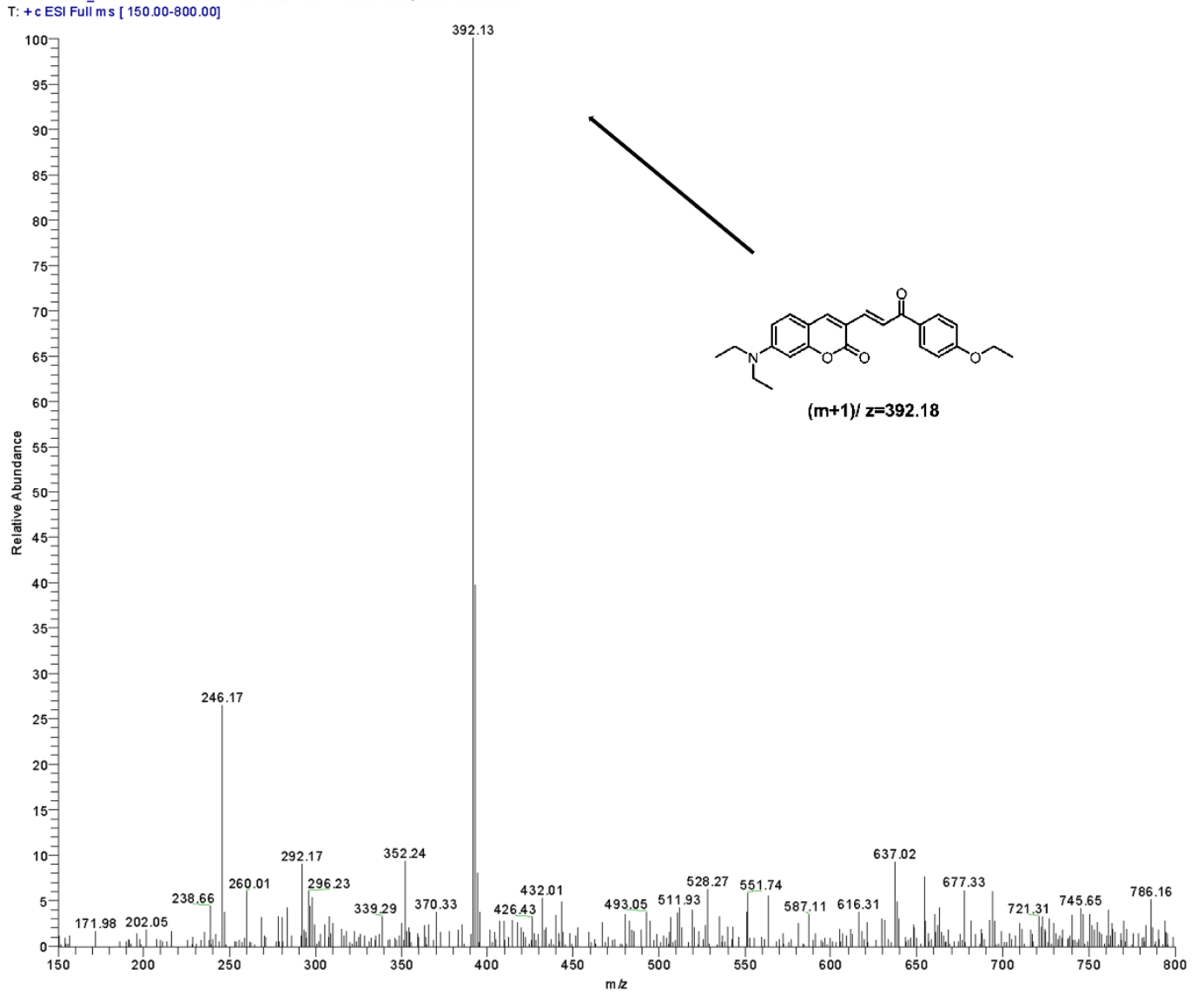

Figure S38. ESI-MS spectrum of compound Bc.

S37 

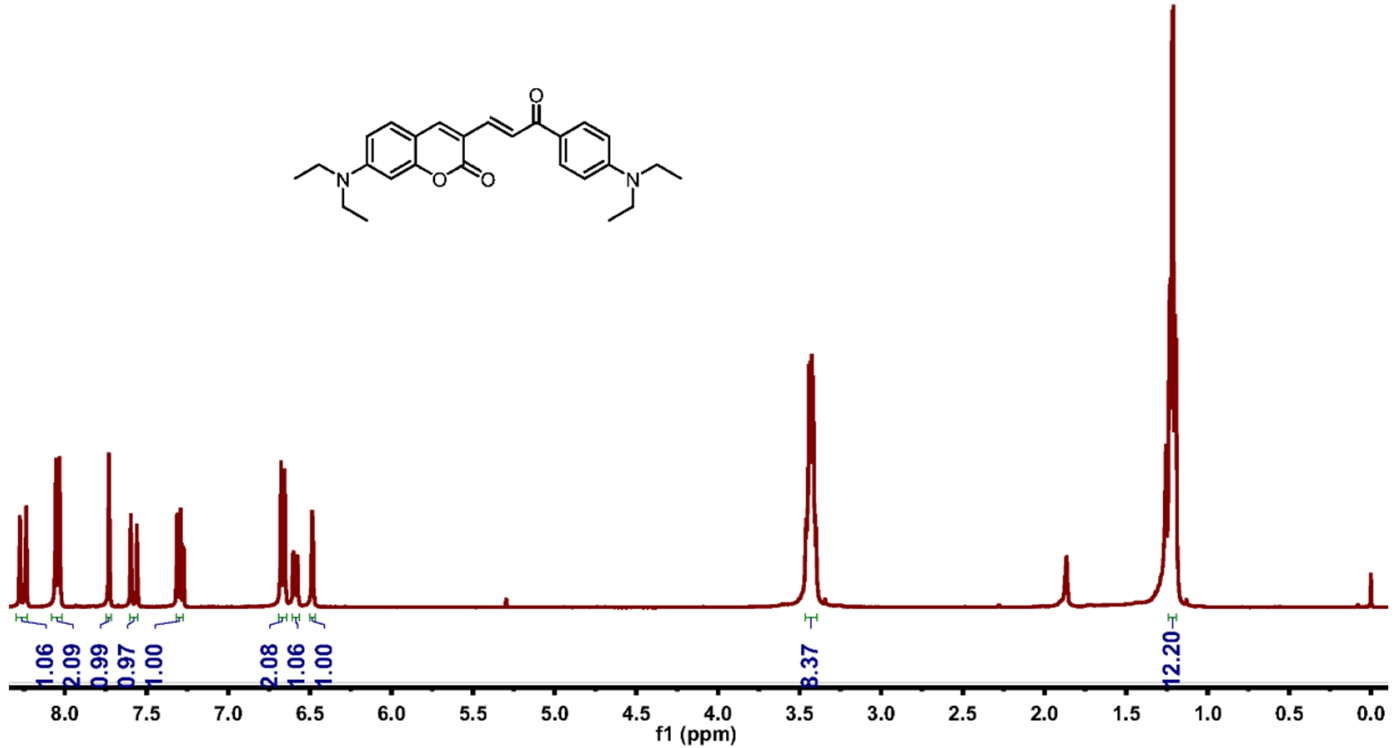

Figure S39. ${ }^{1} \mathrm{H}$ NMR spectra of compound $3 \mathrm{~d}$ recorded in $\mathrm{CDCl}_{3}$.
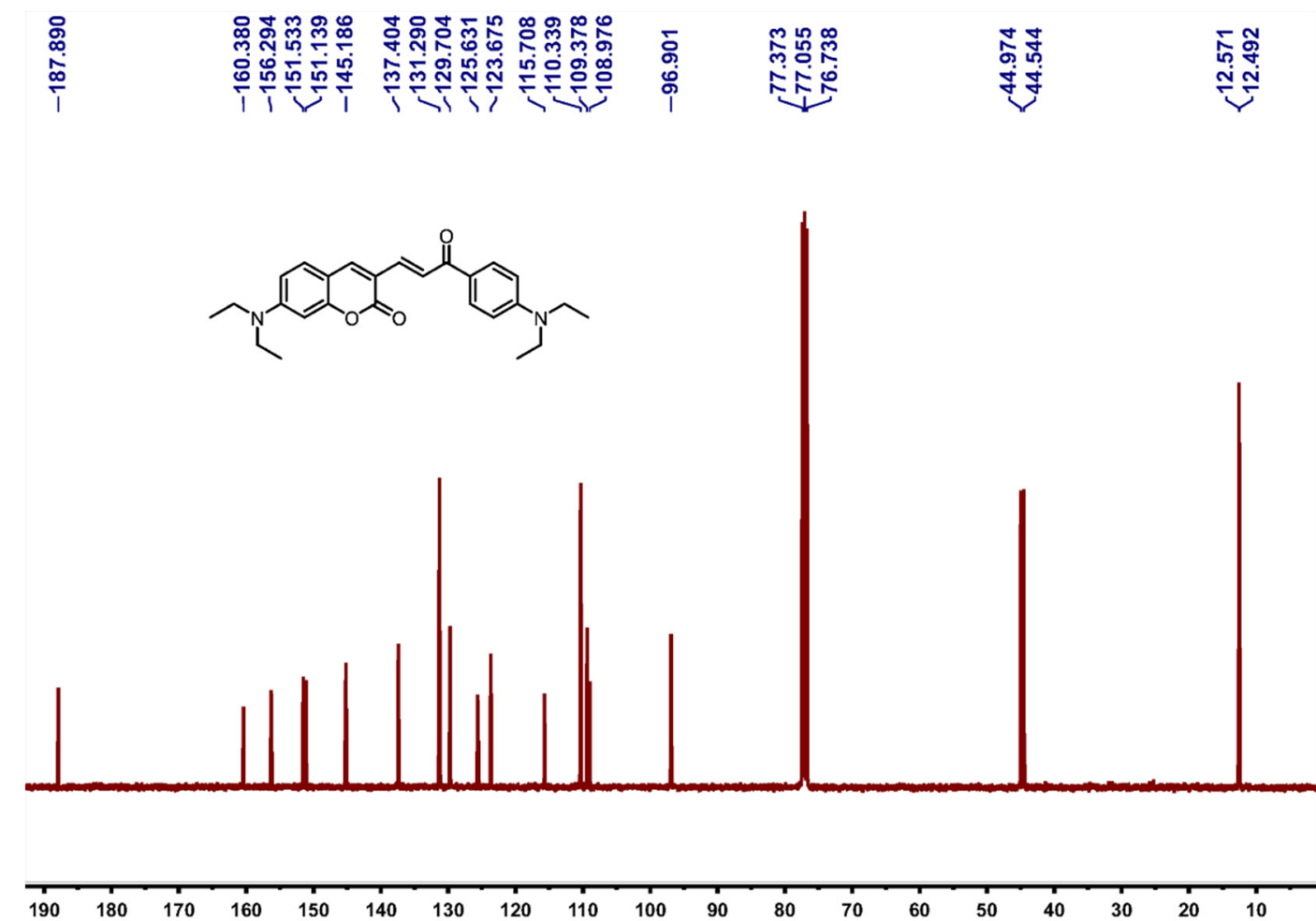

Figure S40. ${ }^{13} \mathrm{C}$ NMR spectra of compound 3d recorded in $\mathrm{CDCl}_{3}$. 
20131217004_131224181701\#1085 RT: 17.27 AV: 1 NL: $4.50 E 7$ T. To ESI Full ms [150:00-1000.00]

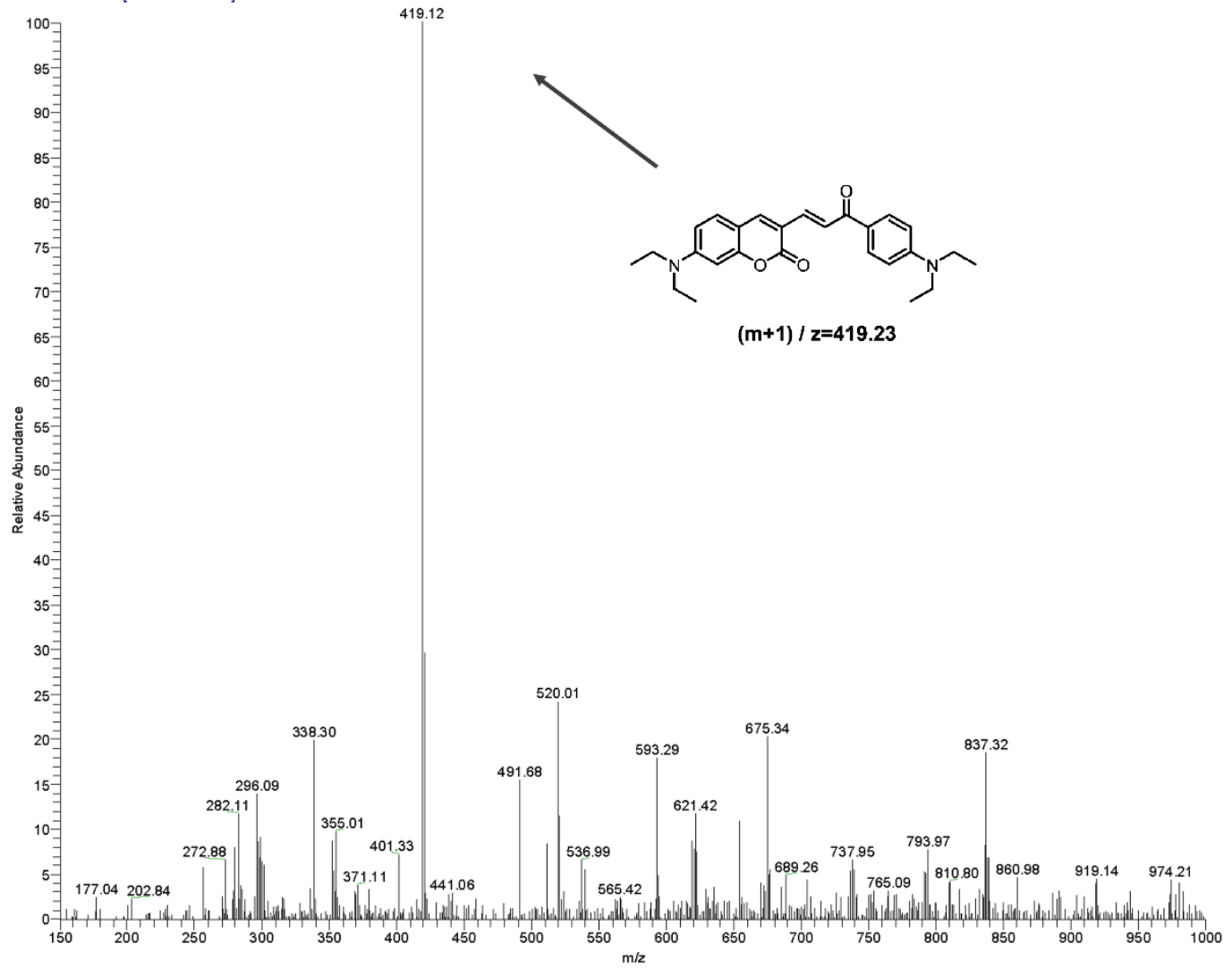

Figure S41. ESI-MS spectrum of compound 3d.
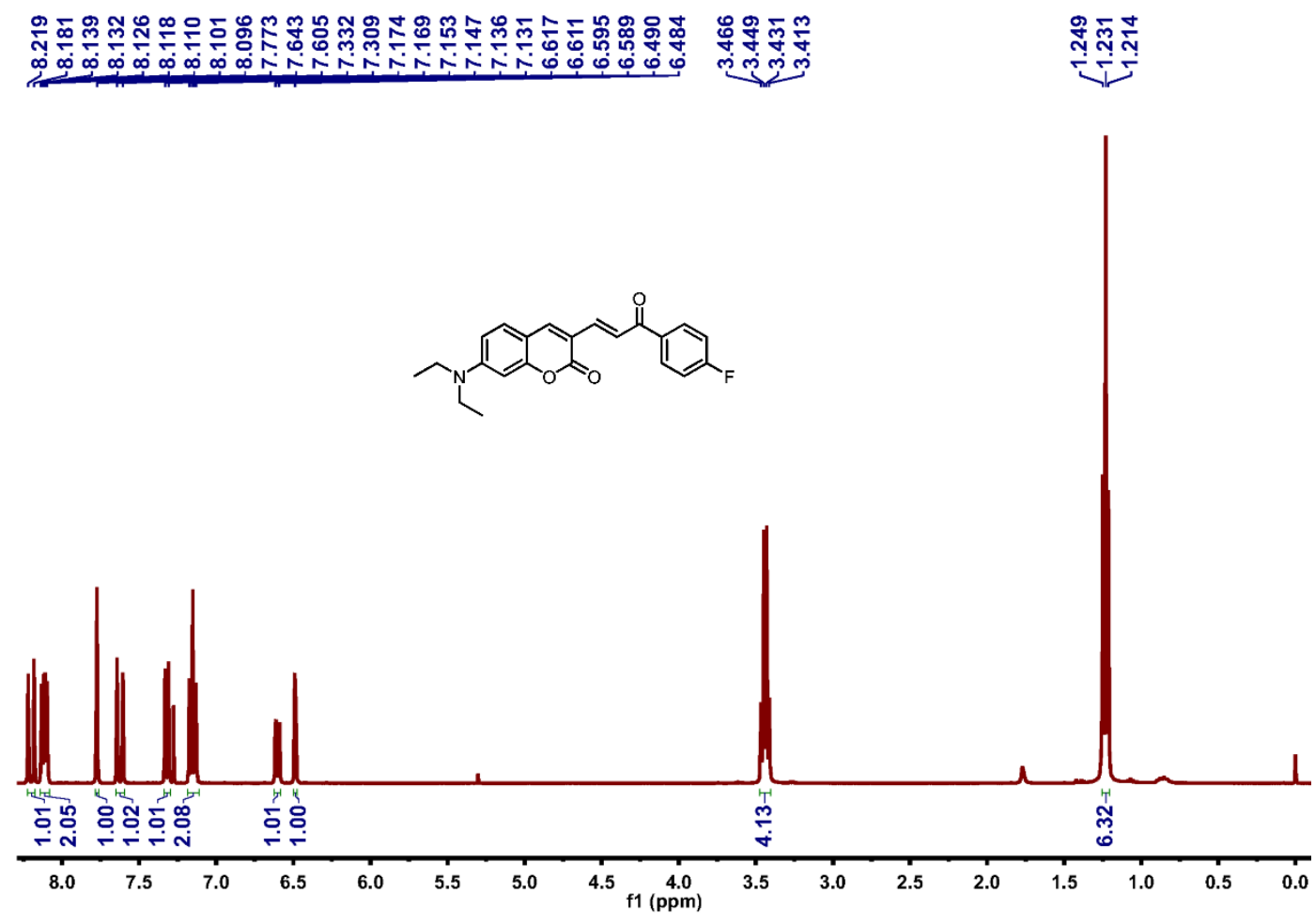

Figure S42. ${ }^{1} \mathrm{H}$ NMR spectra of compound 3e recorded in $\mathrm{CDCl}_{3}$. 



Figure S43. ${ }^{13} \mathrm{C}$ NMR spectra of compound $3 \mathbf{e}$ recorded in $\mathrm{CDCl}_{3}$.

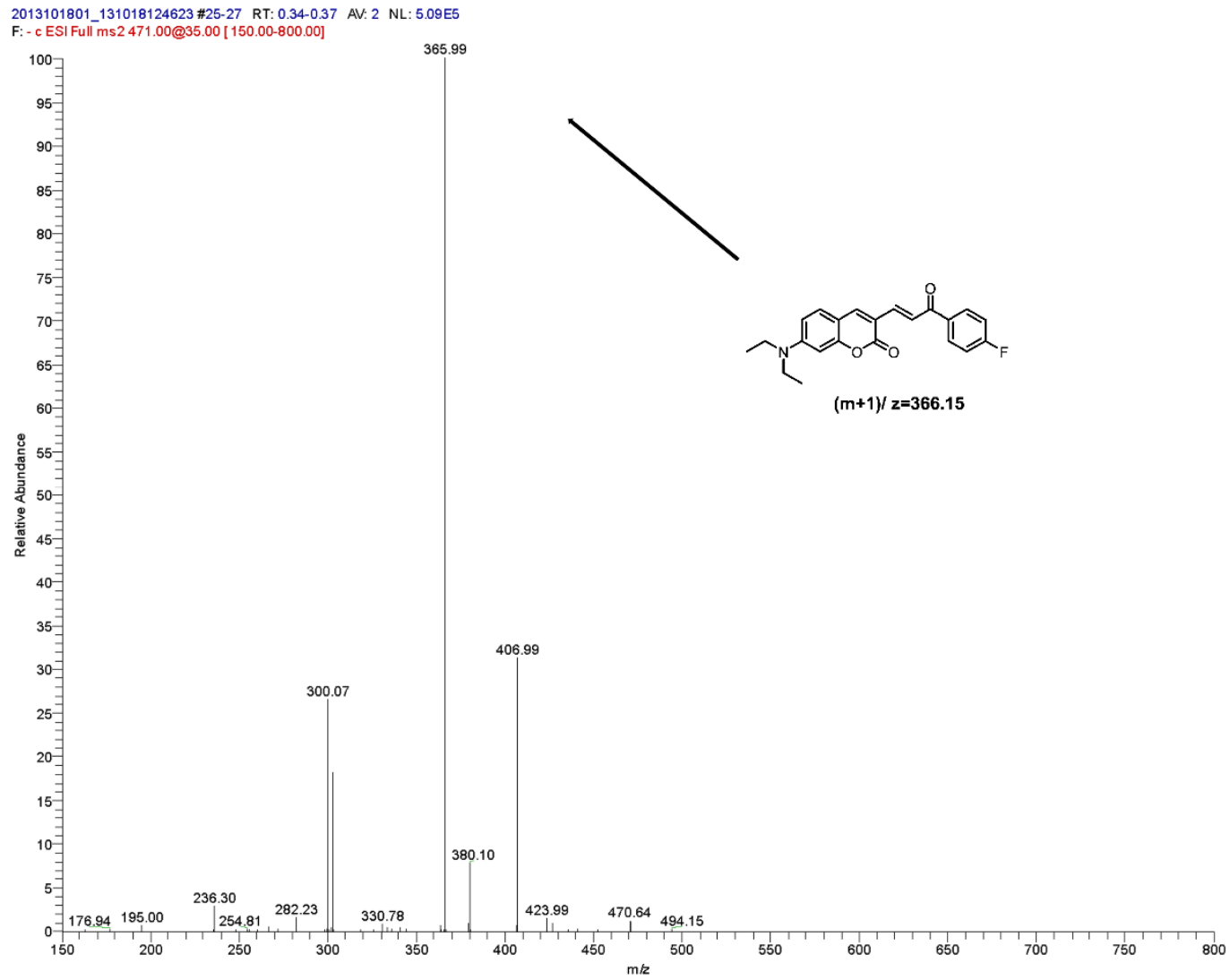

Figure S44. ESI-MS spectrum of compound $3 \mathrm{e}$. 

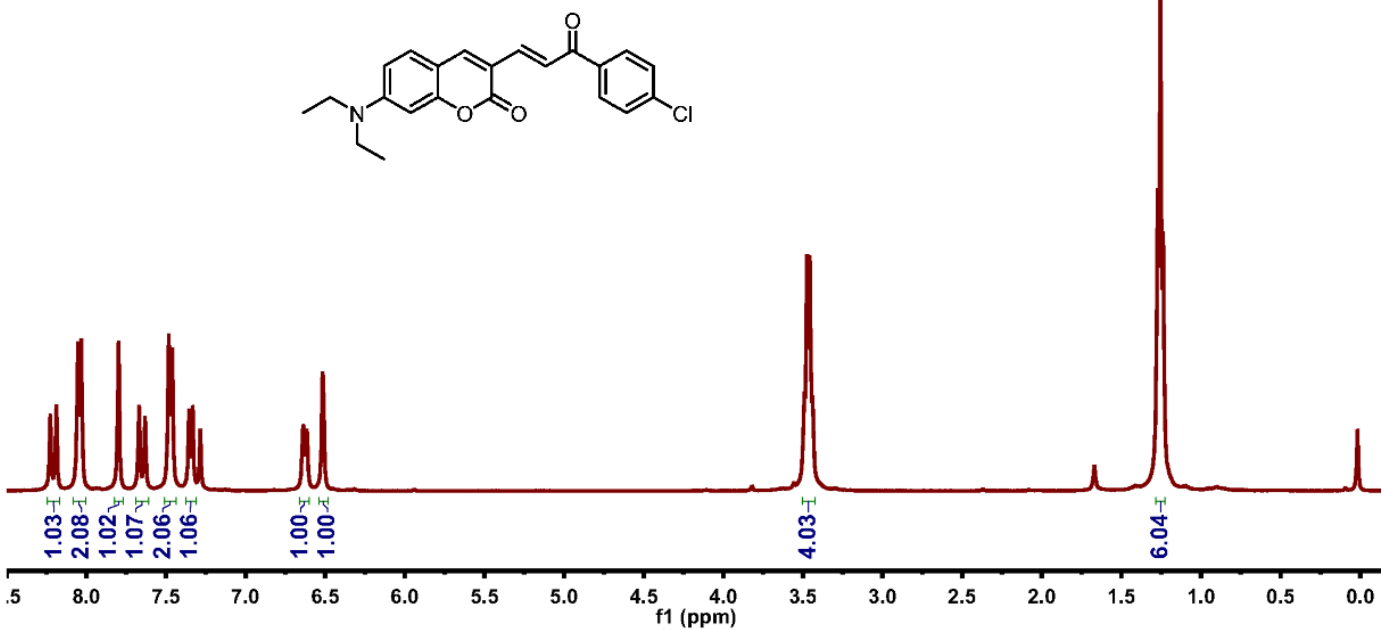

Figure S45. ${ }^{1} \mathrm{H}$ NMR spectra of compound $3 f$ recorded in $\mathrm{CDCl}_{3}$.
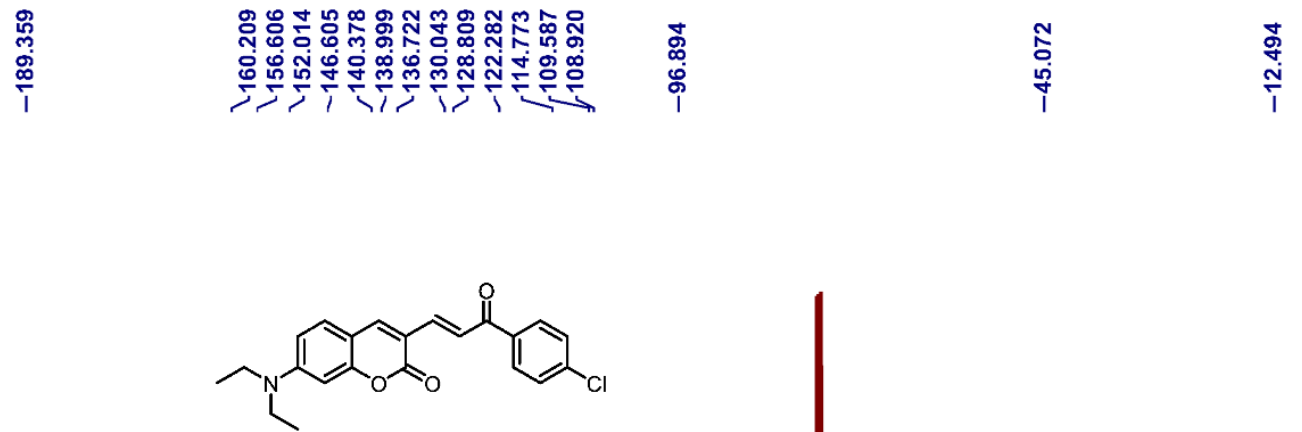

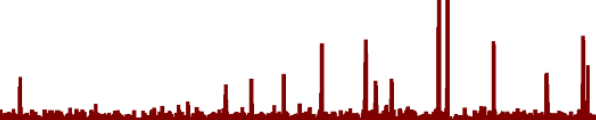

$\begin{array}{lllllllllll}190 & 180 & 170 & 160 & 150 & 140 & 130 & 120 & 110 & 100 \\ \mathrm{f} 1(\mathrm{ppm})\end{array}$

Figure S46. ${ }^{13} \mathrm{C}$ NMR spectra of compound $3 f$ recorded in $\mathrm{CDCl}_{3}$. 


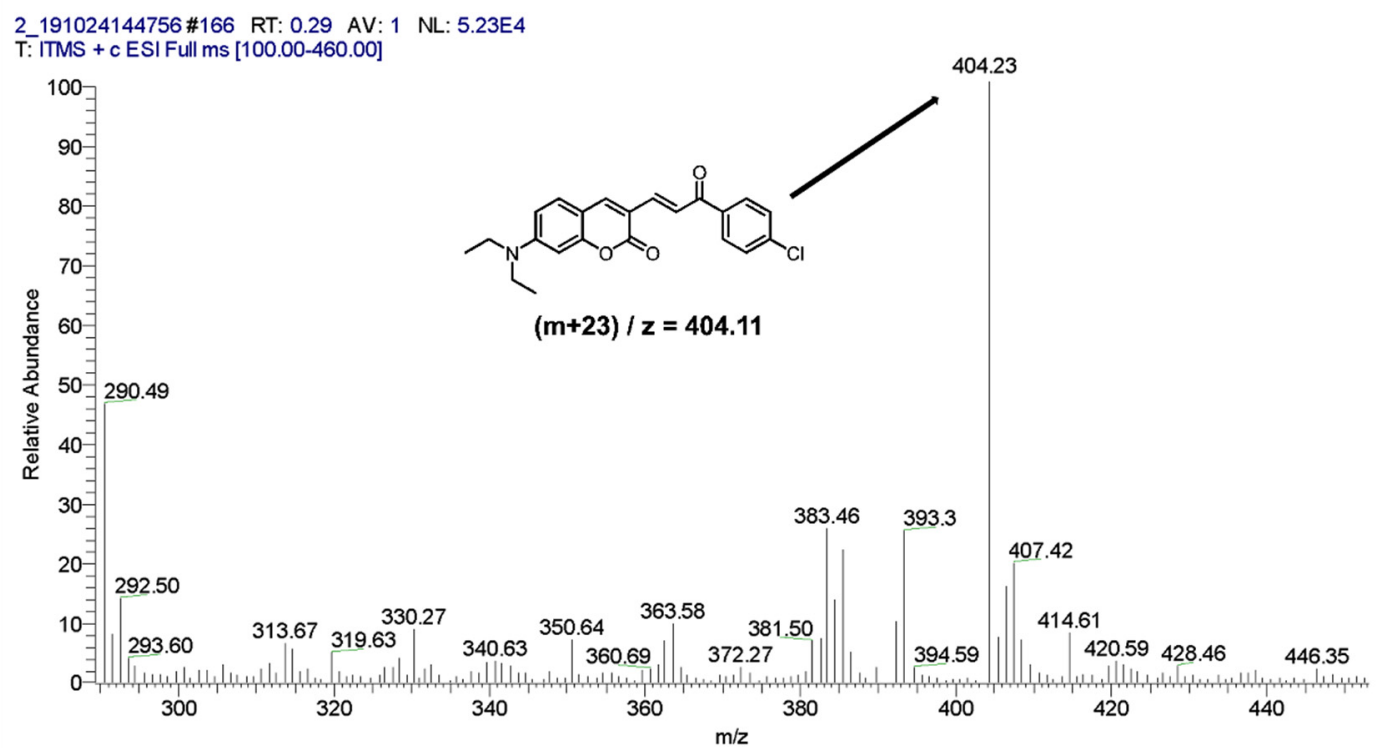

Figure S47. ESI-MS spectrum of compound $3 \mathbf{f}$.
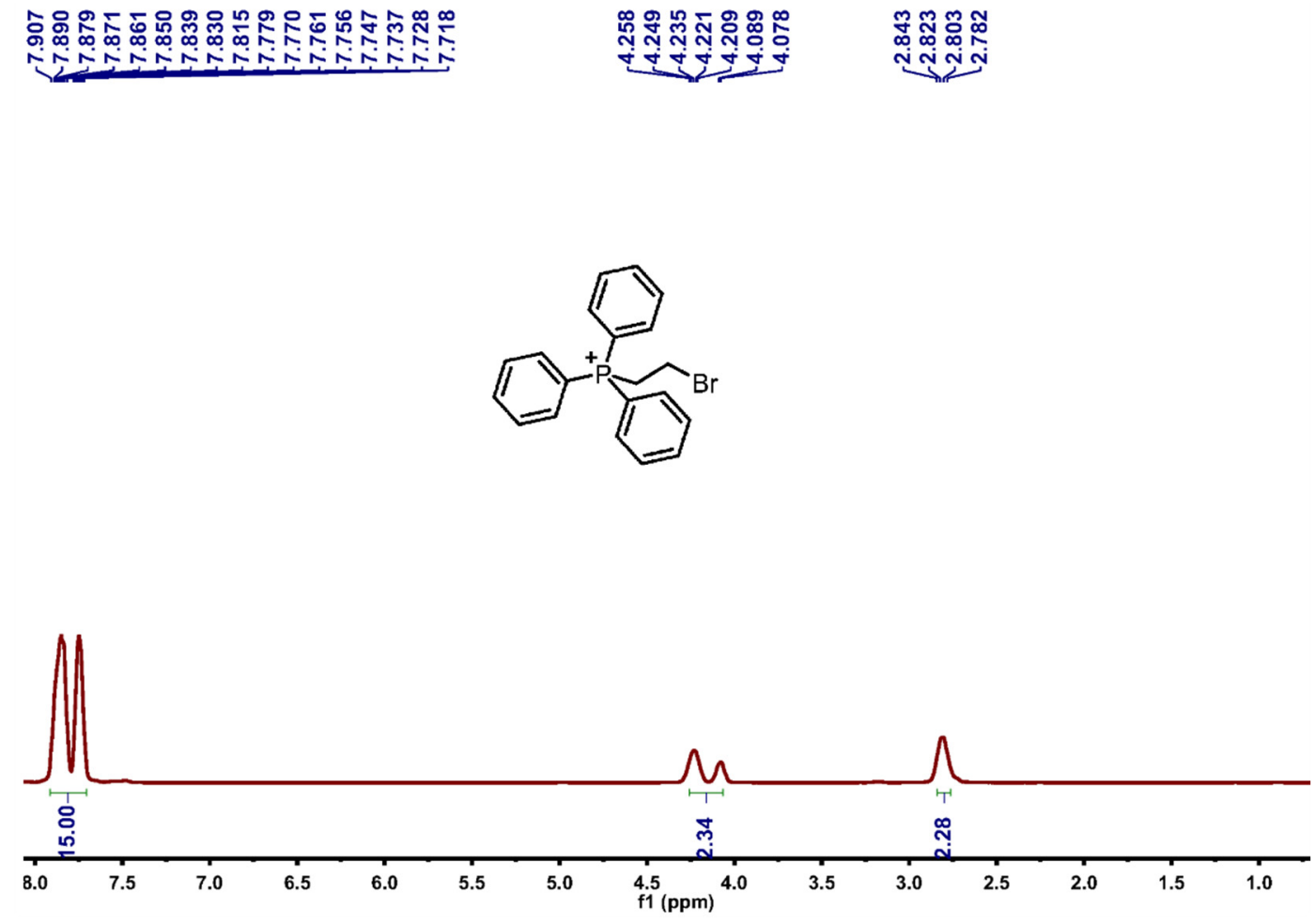

Figure S48. ${ }^{1} \mathrm{H}$ NMR spectra of compound 7 recorded in $\mathrm{CDCl}_{3}$. 



Figure S49. ${ }^{1} \mathrm{H}$ NMR spectra of compound 8 recorded in $\mathrm{CDCl}_{3}$.

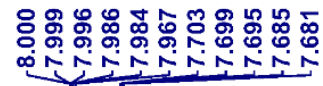

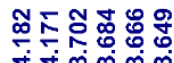

ن̛ं

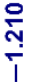
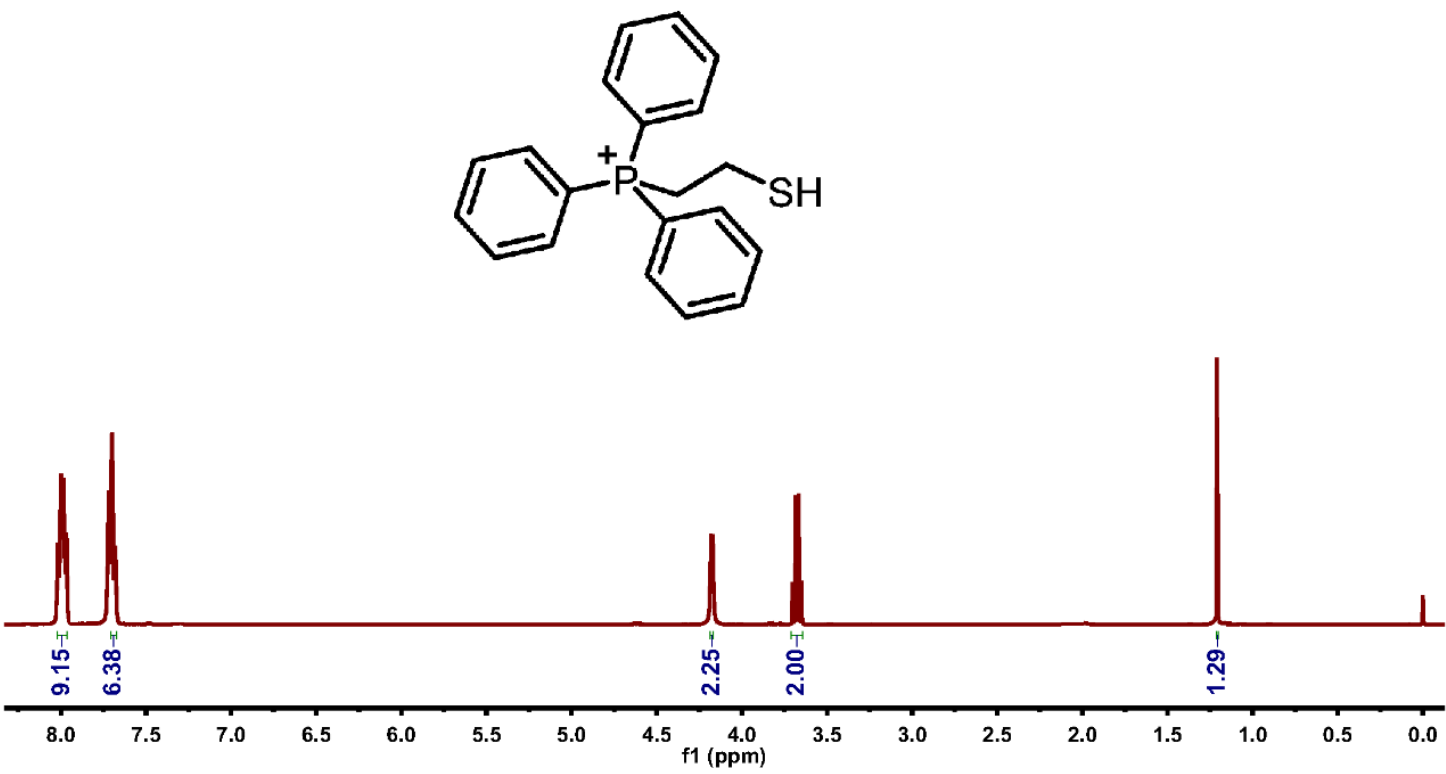

Figure S50. ${ }^{1} \mathrm{H}$ NMR spectra of compound 9 recorded in $\mathrm{CDCl}_{3}$. 

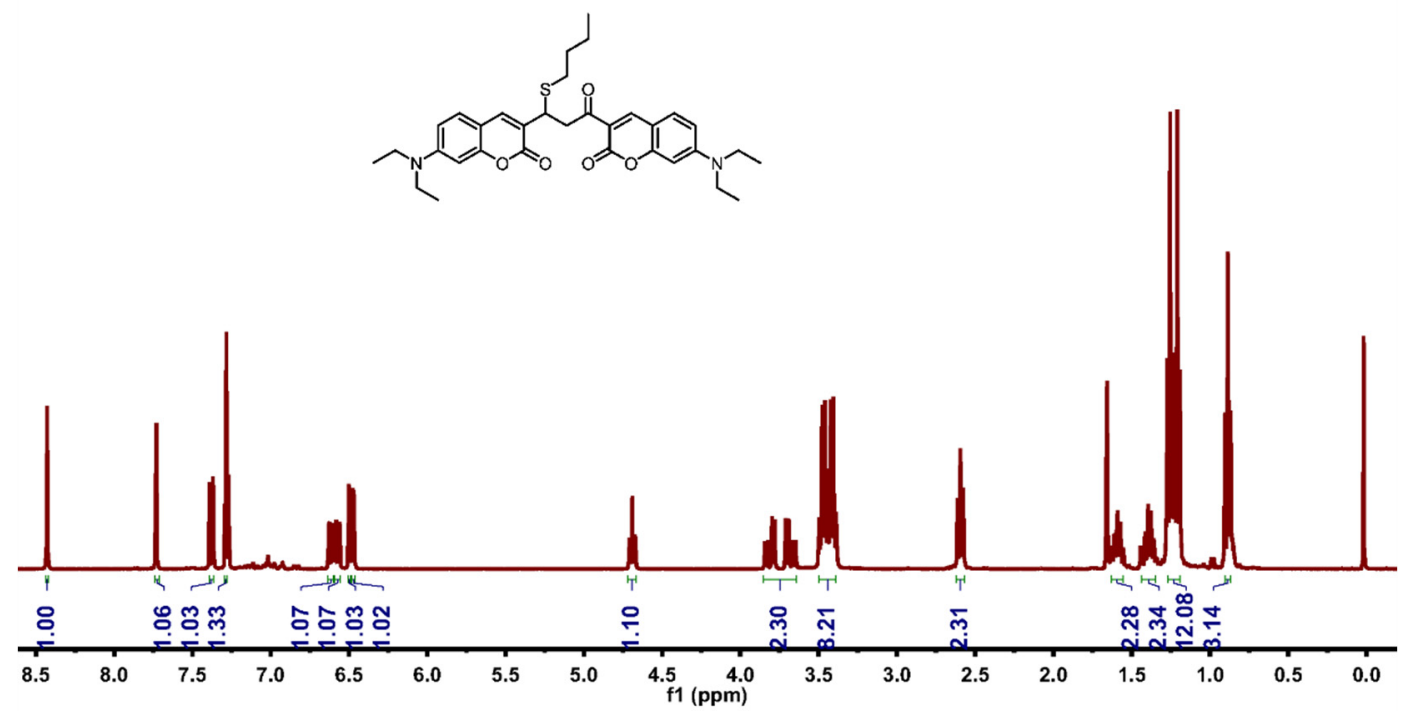

Figure S51. ${ }^{1} \mathrm{H}$ NMR spectra of $\mathbf{H y - 1}$ recorded in $\mathrm{CDCl}_{3}$.
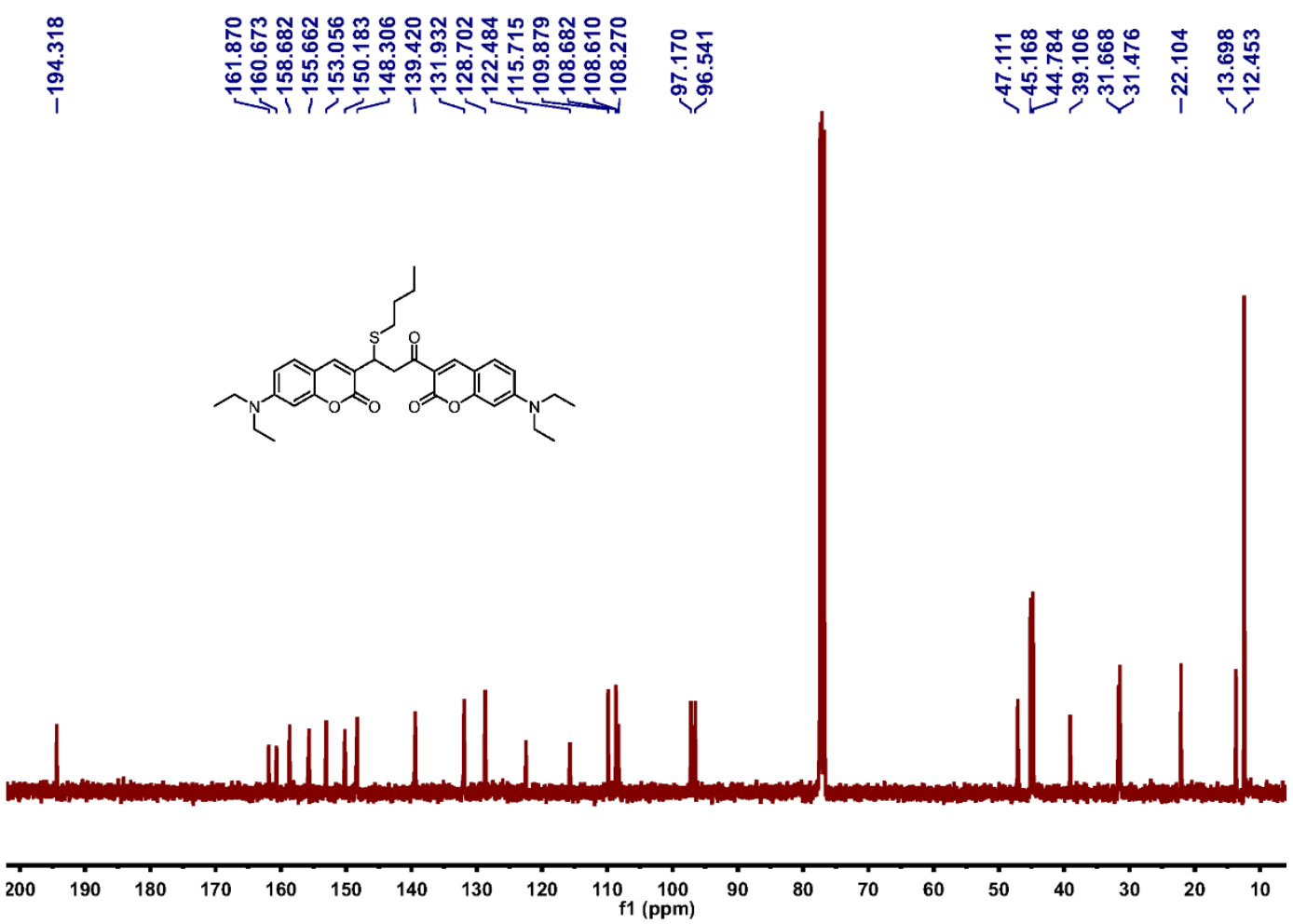

Figure S52. ${ }^{13} \mathrm{C}$ NMR spectra of $\mathbf{H y}-\mathbf{1}$ recorded in $\mathrm{CDCl}_{3}$. 
3_191024144756\#131 RT: 0.21 AV: 1 NL: 7.52E3

T: TMS + c ESI Full ms [480.00-700.00]

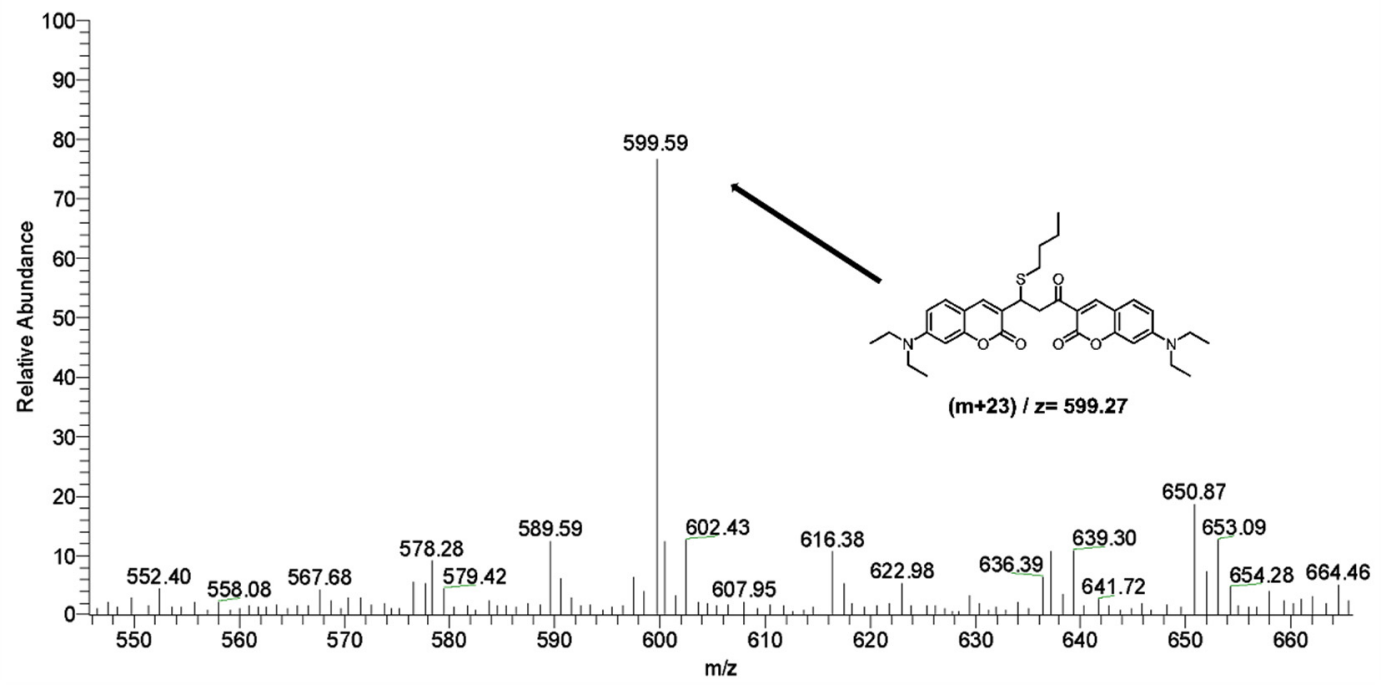

Figure S53. ESI-MS spectrum of Hy-1.

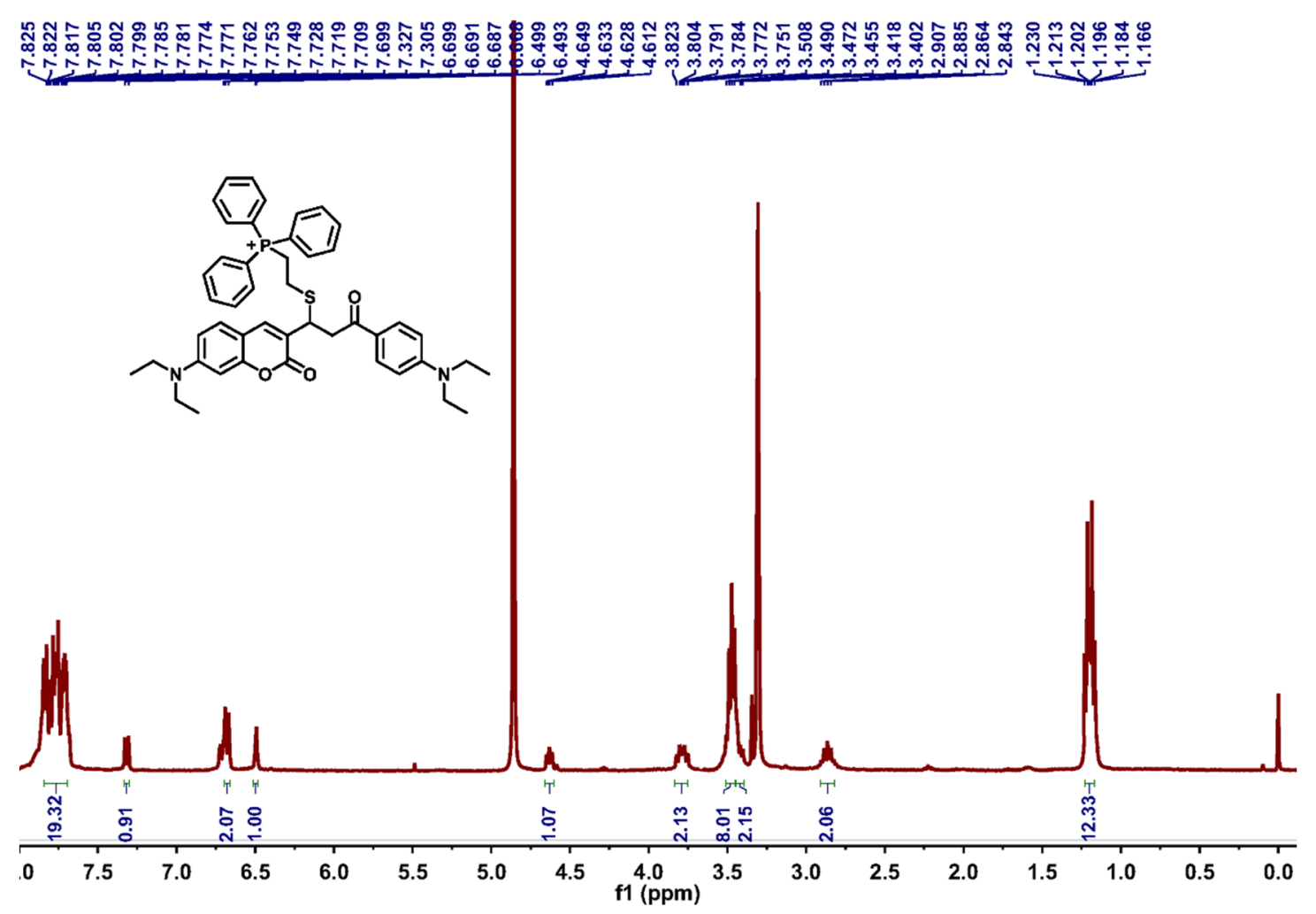

Figure S54. ${ }^{1} \mathrm{H}$ NMR spectra of $\mathbf{H y - 2}$ recorded in methanol- $d 4$. 


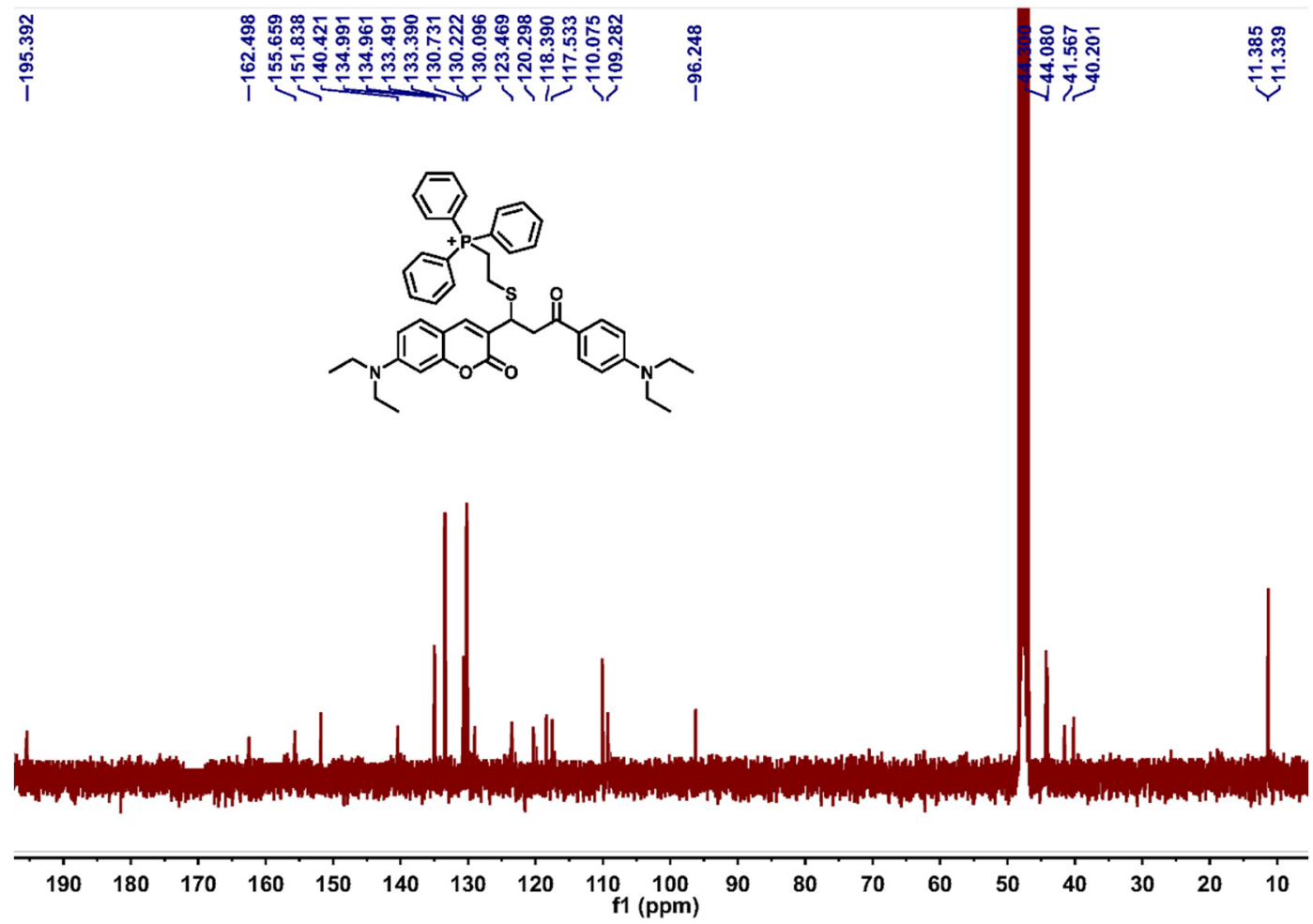

Figure S55. ${ }^{13} \mathrm{C}$ NMR spectra of $\mathbf{H y - 2}$ recorded in methanol- $d 4$.



Figure S56. ESI-MS spectrum of Hy-2. 


\section{References}

(1) Aubry, J.; Cazin, B., Chemical sources of singlet oxygen. 2. Quantitative generation of singlet oxygen from hydrogen peroxide disproportionation catalyzed by molybdate ions. Inorg. Chem. 1988, 27, 2013-2014.

(2) Sun, J.; Song, B.; Ye, Z.; Yuan, J., Mitochondria Targetable Time-Gated Luminescence Probe for Singlet Oxygen Based on a beta-Diketonate-Europium Complex. Inorg. Chem. 2015, 54, 11660-11668.

(3) Kim, S.; Tachikawa, T.; Fujitsuka, M.; Majima, T., Far-Red Fluorescence Probe for Monitoring Singlet Oxygen during Photodynamic Therapy. J. Am. Chem. Soc. 2014, 136, 11707-11715.

(4) Setsukinai, K.; Urano, Y.; Kakinuma, K.; Majima, H. J.; Nagano, T., Development of novel fluorescence probes that can reliably detect reactive oxygen species and distinguish specific species. J. Biol. Chem. 2003, 278, 3170-3175.

(5) Sun, Z. N.; Liu, F. Q.; Chen, Y.; Tam, P. K.; Yang, D., A highly specific BODIPYbased fluorescent probe for the detection of hypochlorous acid. Org. Lett. 2008, 10, 2171-2174.

(6) Yang, Y. K.; Cho, H. J.; Lee, J.; Shin, I.; Tae, J., A rhodamine-hydroxamic acidbased fluorescent probe for hypochlorous acid and its applications to biological imagings. Org. Lett. 2009, 11, 859-861.

(7) Fischer, M.; Georges, J., Fluorescence quantum yield of rhodamine 6G in ethanol as a function of concentration using thermal lens spectrometry. Chem. Phys. Lett. 1996, $260,115-118$.

(8) Parker, C. A.; Rees, W. T., Correction of fluorescence spectra and measurement of fluorescence quantum efficiency. Analyst 1960, 85, 587-600.

(9) Fery-Forgues, S.; Lavabre, D., Are fluorescence quantum yields so tricky to measure? A demonstration using familiar stationery products. J. Chem. Educ. 1999, 76, 1260-1264.

(10) Ajayaghosh, A.; Carol, P.; Sreejith, S., A ratiometric fluorescence probe for selective visual sensing of Zn2+. J. Am. Chem. Soc. 2005, 127, 14962-14963.

(11) Zhu, B.; Gao, C.; Zhao, Y.; Liu, C.; Li, Y.; Wei, Q.; Ma, Z.; Du, B.; Zhang, X., A 4-hydroxynaphthalimide-derived ratiometric fluorescent chemodosimeter for imaging palladium in living cells. Chem. Commun. 2011, 47, 8656-8658.

(12) Gaussian 09, Revision D.01, Frisch, M. J.; Trucks, G. W.; Schlegel, H. B.; Scuseria, G. E.; Robb, M. A.; Cheeseman, J. R.; Scalmani, G.; Barone, V.; Mennucci, B.; Petersson, G. A.; Nakatsuji, H.; M. Caricato; Li, X.; Hratchian, H. P.; Izmaylov, A. F.; Bloino, J.; Zheng, G.; Sonnenberg, J. L.; Hada, M.; Ehara, M.; Toyota, K.; Fukuda, R.; Hasegawa, J.; Ishida, M.; Nakajima, T.; Honda, Y.; Kitao, O.; Nakai, H.; Vreven, T.; Montgomery, J. A.; Jr.; Peralta, J. E.; Ogliaro, F.; Bearpark, M.; Heyd, J. J.; Brothers, E.; Kudin, K. N.; Staroverov, V. N.; Keith, T.; Kobayashi, R.; Normand, J.; Raghavachari, K.; Rendell, A.; Burant, J. C.; Iyengar, S. S.; Tomasi, J.; Cossi, M.; Rega, N.; Millam, J. M.; Klene, M.; Knox, J. E.; Cross, J. B.; Bakken, V.; Adamo, C.; Jaramillo, J.; Gomperts, R.; Stratmann, R. E.; Yazyev, O.; Austin, A. J.; Cammi, R.; Pomelli, C.; Ochterski, J. W.; Martin, R. L.; Morokuma, K.; Zakrzewski, V. G.; Voth, G. A.; Salvador, P.; Dannenberg, J. J.; Dapprich, S.; Daniels, A. D.; Farkas, O.; 
Foresman, J. B.; Ortiz, J. V.; Cioslowski, J.; Fox, D. J., Gaussian, Inc., Wallingford CT, 2013.

(13) Lee, C.; Yang, W.; Parr, R. G., Development of the Colle-Salvetti correlationenergy formula into a functional of the electron density. Phys. Rev. B 1988, 37, 785.

(14) Becke, A. D., Density-functional thermochemistry. III. The role of exact exchange. J. Chem. Phys. 1993, 98, 5648-5652.

(15) Stephens, P.; Devlin, F.; Chabalowski, C.; Frisch, M. J., Ab initio calculation of vibrational absorption and circular dichroism spectra using density functional force fields. J. Phys. Chem. 1994, 98, 11623-11627.

(16) Rassolov, V. A.; Ratner, M. A.; Pople, J. A.; Redfern, P. C.; Curtiss, L. A., 6-31G* basis set for third-row atoms. J. Comput. Chem. 2001, 22, 976-984.

(17) Miertuš, S.; Scrocco, E.; Tomasi, J., Electrostatic interaction of a solute with a continuum. A direct utilizaion of $\mathrm{AB}$ initio molecular potentials for the prevision of solvent effects. Chem. Phys. 1981, 55, 117-129.

(18) Chipman, D. M., Reaction field treatment of charge penetration. J. Chem. Phys. 2000, 112, 5558-5565.

(19) Badawi, H. M.; Forner, W.; Abu-Sharkh, B. F.; Oloriegbe, Y. S., Potential scans and potential energy distributions of normal vibrational modes of trichloroacetyl isocyanate. J. Mol. Model. 2002, 8, 44-49.

(20) Padua, A. A. H., Torsion energy profiles and force fields derived from ab initio calculations for simulations of hydrocarbon-fluorocarbon diblocks and perfluoroalkylbromides. J. Phys. Chem. A 2002, 106, 10116-10123.

(21) Badawi, H. M.; Forner, W.; Ali, S. A., Three rotor potential energy scans, conformational equilibrium constants and vibrational analysis of 3-fluoro-1-propanol $\mathrm{CH}(2) \mathrm{FCH}(2) \mathrm{CH}(2) \mathrm{OH}$. Spectrochim. Acta A Mol. Biomol. Spectrosc. 2008, 69, $263-$ 271. 